\title{
ASPECTOS DA ANÁLISE ESTRUTURAL DAS LAJES DE EDIFÍCIOS DE CONCRETO ARMADO
}

HERALDO DUARTE

Dissertação apresentada à Escola de Engenharia de São Carlos, da Universidade de São Paulo, como parte dos requisitos para a obtenção do Título de Mestre em Engenharia de Estruturas

ORIENTADOR: JOSÉ SAMUEL GIONGO

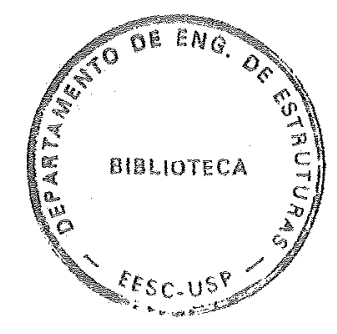

São Carlos 1998 
Class. TESE-E

Cutt.

주:=

Ficha catalográfica preparada pela Seção de Tratamento

da Inform açấo do Serviço de Biblioteca - EESC-USP

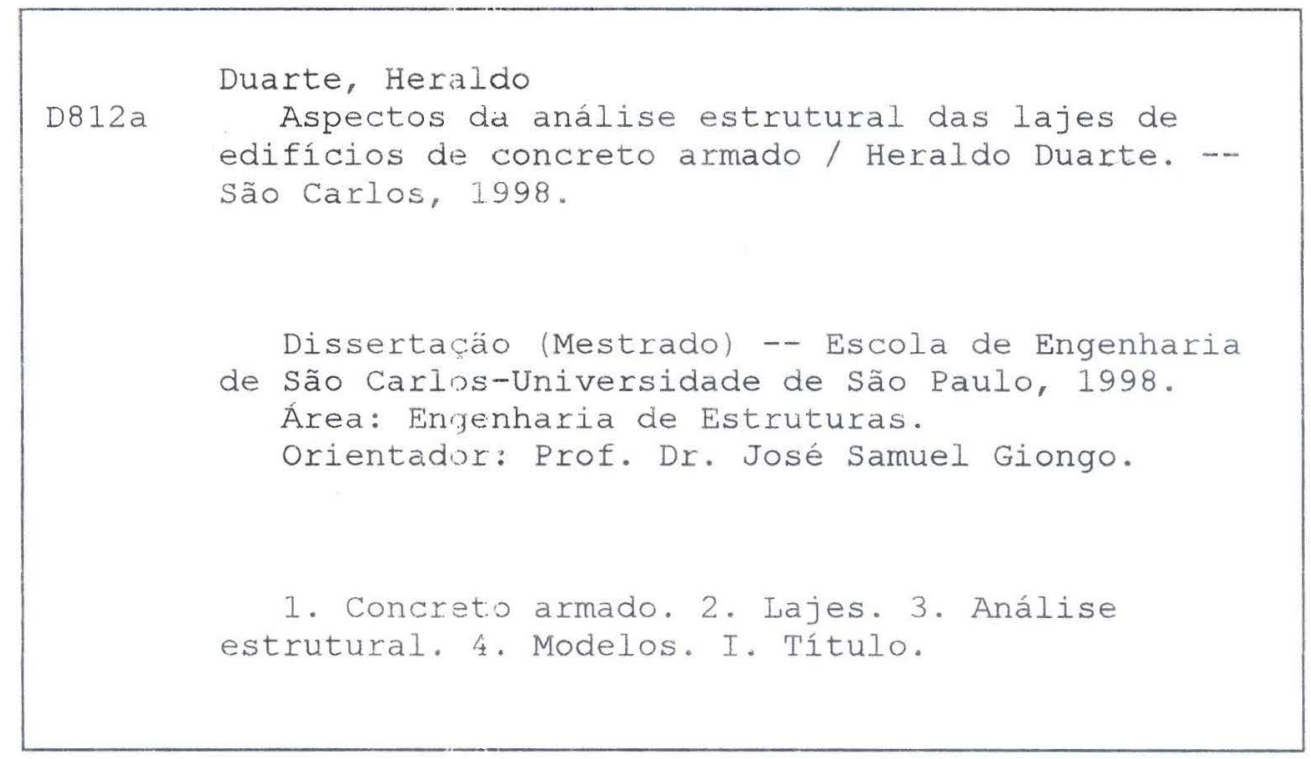




\section{FOLHA DE APROVACÃO}

Candidato: Engenheiro HERALDO DUARTE

Dissertação defendida e aprovada em 20-03-1998 pela Comissão Julgadora:

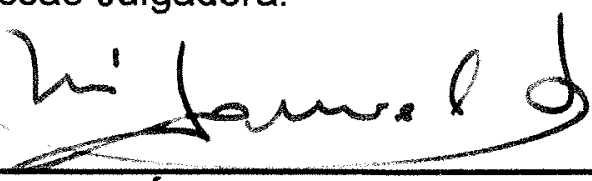

Prof. Doutor JOSÉ SAMUEL GIONGO (Orientador)

(Escola de Engenharia de São Carlos - Universidade de São Paulo)

Conceito atribuido ao candidato: Aprovado

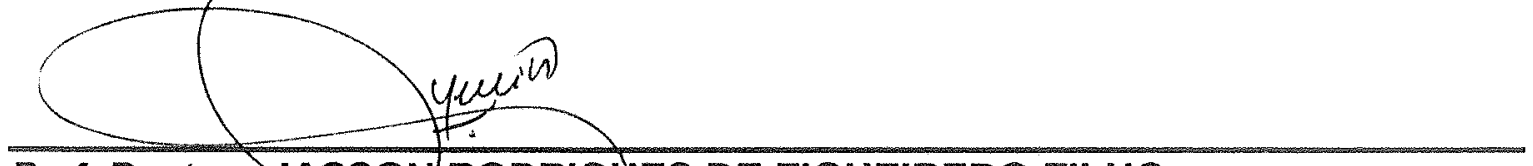

Prof. Doutor JASSON RODRIGUUES DE FIGUEIREDO FILHO

(Universidade Federal de São Carlos - UFSCar)

Conceito atribuído ao candidato: Aprovado
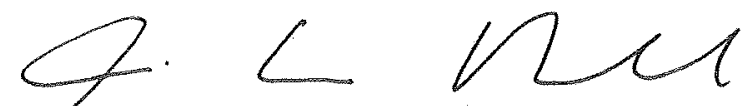

Prof. Doytor MARCIO ANTONIO RAMALHO

(Escola de Engenharia de São Carlos - Universidade de São Paulo)

Conceito atribuido ao candidato: Reprovado

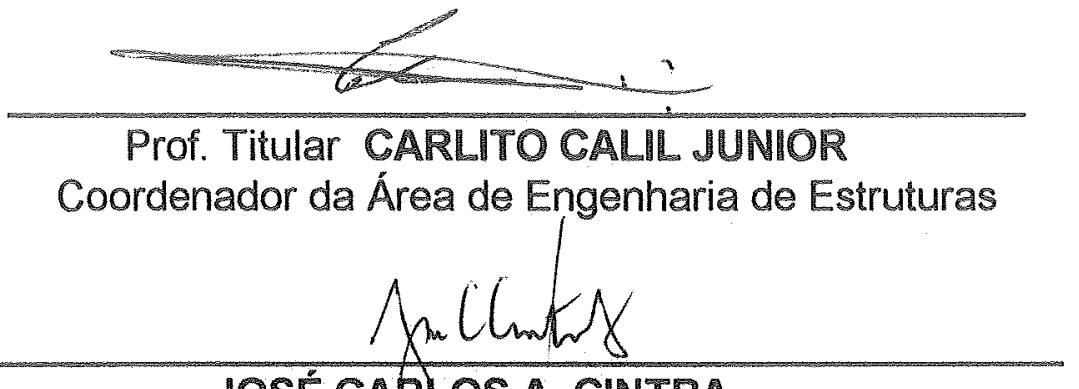

JOSÉ CARLOS A. CINTRA

Presidente da Comissão de Pós-Graduação 
Para minha esposa e filho, Rosana e Gabriel 


\section{AGRADECIMENTOS}

Ao Prof. José Samuel Giongo, pela atenção dispensada na orientação deste trabalho, pelas experiências e conhecimentos transmitidos e, principalmente, pela sua amizade

Ao Departamento de Estruturas da Escola de Engenharia de São Carlos, por permitir e dar todas as condições para a realização deste trabalho.

Ao Escritório Técnico José Roberto Leme de Andrade S/C Ltda., por ceder cópias de projeto de sua propriedade para serem utilizadas como exemplos.

À Sra. Maria Nadir Minatel, pela ajuda com a bibliografía.

À Secretária Rosi Aparecida Jordão Rodrigues, pela dedicação e serviços prestados.

Aos meus familiares e a toda familia de fé são carlense pelo apoio e incentivo a esse trabalho.

À CAPES, pela bolsa de estudos.

A todos aqueles que, de alguma forma, contribuíram para a realização deste trabalho e, acima de tudo, a Deus, que é Pai providente, fonte de toda ciência e sabedoria. 


\section{SUMÁRIO}

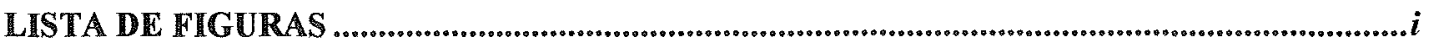

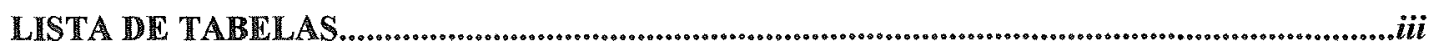

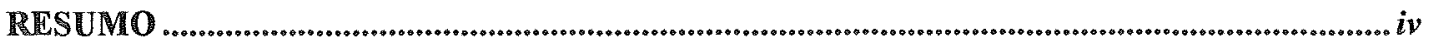

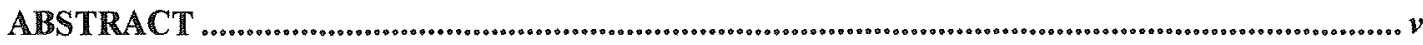

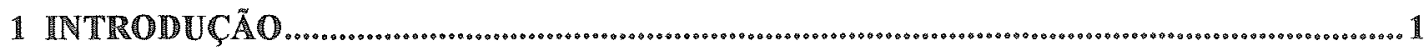

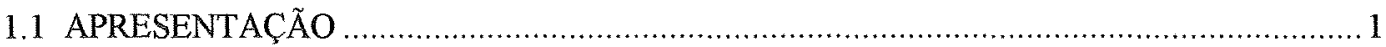

1.2 OBJETIVOS

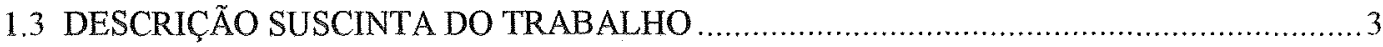

2. ACOOES, PRĹ-DIMENSIONAMENTO C DISPOSIÇOEES CONSTRUTIVAS A

CONSIDERAR NOS PROJUTOS DE EDIFÍCIOS ................................................................... 4

2.1 INTRODUÇÃO

2.2 AÇÕES A CONSIDERAR NOS PROJETOS DE EDIFICIOS .....................................

2.3 PRÉ-DIMENSIONAMENTO

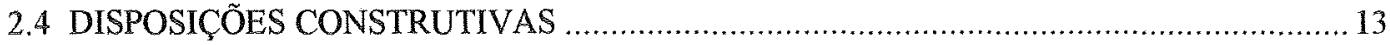

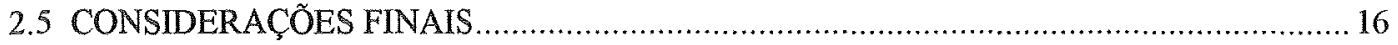

3 TIPOS DE ANÁLISE ESTRUTURAL IE SEUS FUNIAMMENTOS TEÓRICOS PARA OS

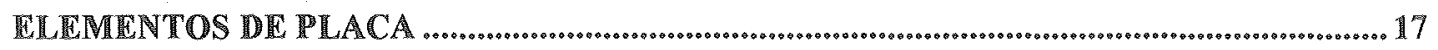

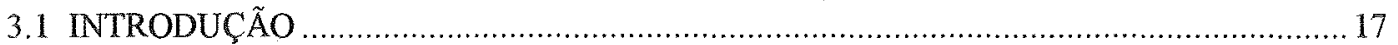

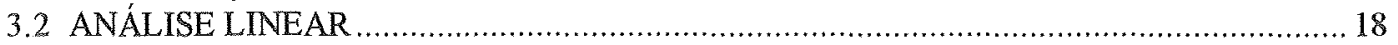

3.2.1 Fundamentos teóricos da análise linear dos elementos de placa................................. 19

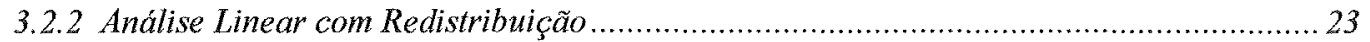

3.3 ANÁLISE LIMITE OU PLÁSTICA

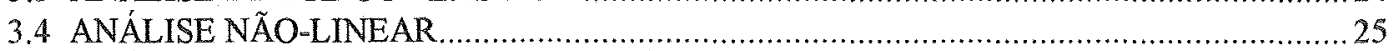

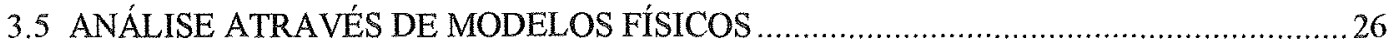

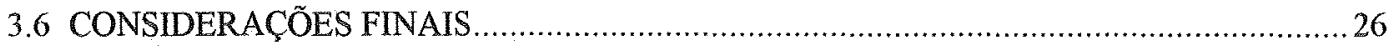

4 MODELOS ESTRUTURAIS PARA ANÁLISE LINEAR DAS LAJES DE EDIFÍCIOS ...... 28

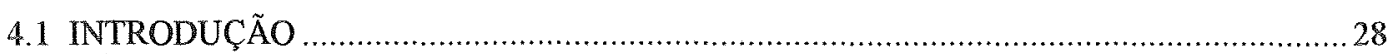

4.2 CÁLCULO APROXIMADO MEDIANTE O USO DE TABELAS - MÉTODO ELÁSTICO32

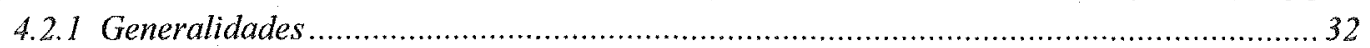

4.2.2 Aplicação sobre o pavimento tipo do edifício Vitória Régia ......................................... 32

4.3 CÁLCULO ATRAVÉS DA TÉCNICA DA ANALOGIA DE GRELHA ..............................33

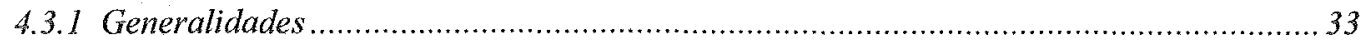

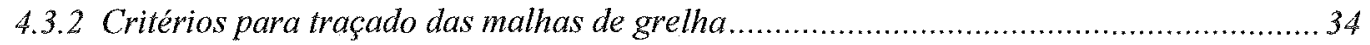

4.3.3 Aplicação sobre o pavimento tipo do edificio Vitória Régia ........................................... 36

4.4 ANÁLISE ATRAVÉS DO MÉTODO DOS ELEMENTOS FINITOS ............................41

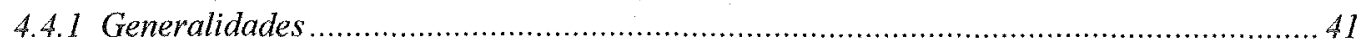


4.4.2 Caracteristicas do método e modelos de elementos finitos

4.4.3 Compatibilidade de elementos e critérios de convergência....................................44

4.4.4 Aplicação sobre o pavimento tipo do edifício Vitória Régia .................................. 46

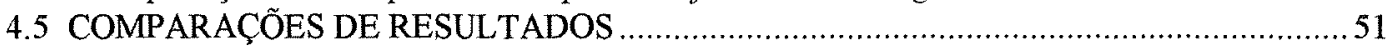

\section{MODELO ESTRUTURAL PARA ANÁLISE LIMITE OU PLÁSTICA DAS LAJES DE} EDIFÍCIOS .53

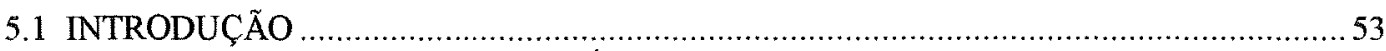

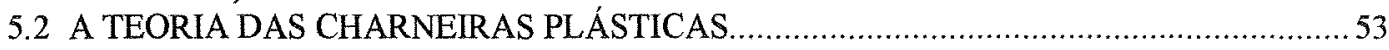

5.2.1 Hipóteses de Cálculo..................................................................................... 54

5.2 .2 Configurações das charneiras ..................................................................... 55

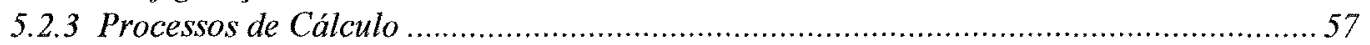

5.3 ANÁLISE DO PAVIMENTO TIPO DO EDIFICIO VITÓRIA RÉGIA ATRAVÉS DA

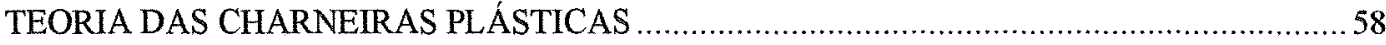

6 DISTRIBUIC్AO DAS ARMADURAS

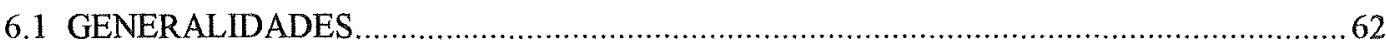

6.2 MODELOS ANALISADOS ATRAVÉS DA TEORIA DA ELASTICIDADE ......................63

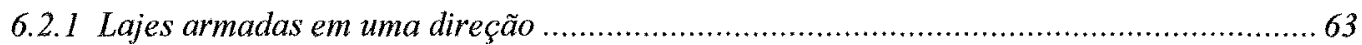

6.2 .2 Lajes armadas em duas direções................................................................. 64

6.2.3 Distribuição das armaduras segundo envoltórias de esforços resultantes de análises através de softwares com pós processadores..............................................................65

6.2.4 Detalhamentos das armaduras obtidos para o pavimento tipo do edificio Vitória Régia 66 6.3 MODELO ANALISADO ATRAVÉS DA TEORIA DAS CHARNEIRAS PLÁSTICAS ......70 6.4 UTILIZAÇÃO DE TELAS SOLDADAS NO DIMENSIONAMENTO DE PAVIMENTOS DE EDIFÍCIOS.

6.5 COMPARAÇÖES ENTRE OS MODELOS ANALISADOS ….................................... 77

7 CONCLUSOLCS..............

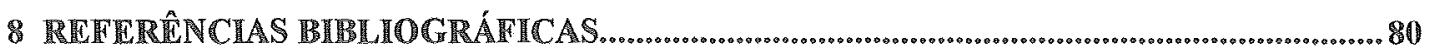




\section{LISTA DE FIGURAS}

FIGURA 3.1- Esforços solicitantes em um elemento de placa ........................................20

FIGURA 4.1 - Forma do pavimento tipo do Edifício Vitória Régia ...................................22

FIGURA 4.2 - Diagrama de deformação da seção de maior momento fletor - Equação de Compatibilidade

FIGURA 4.3 - Malha com espaçamento da ordem de 1,00 $\mathrm{m} \times 1,00 \mathrm{~m}$ - Numeração dos nós

FIGURA 4.4 - Malha com espaçamento da ordem de 0,50 $\mathrm{m} \times 0,50 \mathrm{~m}$ - Numeração dos nós

FIGURA 4.5 - Momentos fletores ao longo do Corte XX (ver Figuras 4.3 e 4.4), obtidos através da aplicação da técnica da analogia de grelha

FIGURA 4.6 - Momentos fletores ao longo do Corte $Y Y$ (ver Figuras 4.3 e 4.4), obtidos através da aplicação da técnica da analogia de grelha

FIGURA 4.7 - Deslocamentos ao longo do Corte XX (ver Figuras 4.3 e 4.4), obtidos através da aplicação da técnica da analogia de grelha .41

FIGURA 4.8 - Momentos fletores ao longo do Corte XX (ver Figuras 4.3 e 4.4), obtidos através da análise com o método dos elementos finitos

FIGURA 4.9 - Momentos fletores ao longo do Corte $Y$ (ver Figuras 4.3 e 4.4 ), obtidos através da análise com o método dos elementos finitos

FIGURA 4.10 - Deslocamentos ao longo do Corte XX (ver Figuras 4.3 e 4.4), obtidas através da análise com o método dos elementos finitos

FIGURA 4.11 - Deslocamentos ao longo do Corte $Y$ (ver Figuras 4.3 e 4.4 ), obtidas através da análise com o método dos elementos finitos

FIGURA 4.12 - Envoltórias dos esforços momentos fletores $M_{11}=M_{x x}(e m ~ k N m / m)$, obtidas através da análise com o método dos elementos finitos

FIGURA 4.13 - Envoltórias dos esforços momentos fletores $M_{22}=M_{y y}(e m k N m / m)$, obtidas através da análise com o método dos elementos finitos

FIGURA 5.1 - Configurações possíveis de charneiras .56

FIGURA 5.2 - Determinação da configuração de ruína

FIGURA 5.3 - Comparações entre os valores dos momentos fletores ao longo do Corte XX (ver tabela 5.1), obtidos através da teoria das charneiras plásticas e do cálculo com tabelas do método elástico

FIGURA 5.4 - Comparações entre os valores dos momentos f́letores ao longo do Corte $\mathrm{Yr}$ (ver tabela 5.1), obtidos através da teoria das charneiras plásticas e do cálculo com tabelas do método elástico 
FIGURA 6.1 - Arranjos possiveis para armadura de lajes contínuas 64

FIGURA 6.2 - Detalhamento das armaduras positivas, obtido através de tabelas do método elástico

FIGURA 6.3 - Detalhamento das armaduras negativas, obtido através de tabelas do método elástico .68

FIGURA 6.4 - Detalhamento das armaduras positivas, obtido através do método dos elementos finitos

FIGURA 6.5 - Detalhamento das armaduras negativas, obtido através do método dos elementos finitos

FIGURA 6.6 - Detalhamento das armaduras positivas, obtido através da teoria das charneiras plásticas

FIGURA 6.7 - Detalhamento das armaduras negativas, obtido através da teoria das charneiras plásticas

FIGURA 6.8 - Detalhamento das armaduras positivas, obtido com a utilização de telas soldadas 75

FIGURA 6.9 - Detalhamento das armaduras negativas, obtido com a utilização de telas soldada 


\section{LISTA DE TABELAS}

TABELA 2.1 - Valores dos pesos específicos aparentes dos materiais de construção 6

TABELA 2.2 - Ações permanentes por unidade de área 7

TABELA 2.3 - Valores mínimos das ações variáveis normais ............................................ 8

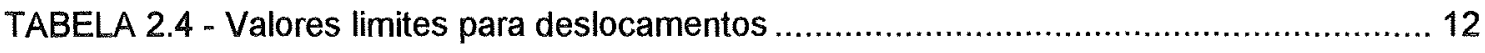

TABELA 4.1 - Momentos fletores e deslocamentos obtidos através do cálculo desenvolvido com auxílio de tabelas - método elástico 33

TABELA 4.2 - Momentos fletores e deslocamentos ao longo do Corte XX (ver figuras 4.3 e 4.4) obtidos através da aplicação da técnica da analogia de grelha 38

TABELA 4.3 - Momentos fletores e deslocamentos ao longo do Corte $Y Y$ (ver figuras 4.3 e 4.4) obtidos através da aplicação da técnica da analogia de grelha

TABELA 4.4 - Momentos Fletores e deslocamentos ao longo do Corte XX (ver Figuras $4.3 \mathrm{e}$ 4.4), obtidos através da análise com o método dos elementos finitos 46

TABELA 4.5 - Momentos Fletores e deslocamentos ao longo do Corte $Y$ (ver Figuras $4.3 \mathrm{e}$ 4.4), obtidos através da análise com o método dos elementos finitos

TABELA 5.1 - Comparação entre os valores dos esforços momentos fletores obtidos através da teoria das charneiras plásticas e cálculo através de tabelas do método elástico 59

TABELA 6.1 - Consumo de aço resultante da análise através de tabelas do método elástico

TABELA 6.2 - Consumo de aço resultante da análise através do método dos elementos finitos

TABELA - 6.3 - Consumo de aço resultante da análise através da teoria das charneiras plásticas

TABELA 6.4 - Consumo de aço resultante do dimensionamento através da utilizaçäo de telas soldadas 


\title{
RESUMO
}

\begin{abstract}
DUARTE, H. (1998). Aspectos da análise estrutural das lajes de edificio de concreto armado. 84p. Dissertação (Mestrado) - Escola de Engenharia de São Carlos, Universidade de São Paulo.
\end{abstract}

A análise estrutural dos pavimentos de edifícios vem se constituindo de recursos cada vez mais refinados, com a difusão de inúmeros "softwares", dotados de pré e pósprocessadores que possibilitam análises precisas, com a consideração da interação entre as rigidezes de todos os elementos que compöem o sistema estrutural do pavimento. Entretanto, há que se ressaltar que, diante desta ampla disponibilidade de recursos, os cálculos simplificados não podem ser deixados de lado nas análises dos projetistas, uma vez que propiciam confirmações dos resultados fornecidos por um "software". Assim sendo, o presente trabalho apresenta alguns aspectos da análise estrutural das lajes de edifícios, abordando conceitos relativos a ações e disposições construtivas a considerar nos projetos, ao pré-dimensionamento das lajes e aos tipos de análise estrutural possiveis de serem realizadas.

São apresentados alguns modelos esîruturais para análise linear das lajes de edifícios, a saber, o cálculo aproximado mediante tabelas do método elástico, a técnica da analogia de grelha e o método dos elementos finitos, mostrando as particularidades de cada um e definindo até que ponto cada um deles pode ser aplicado com segurança, apresentando resultados coerentes para o comportamento estrutural.

No regime elasto-plástico, é apresentado um modelo estrutural de análise através da teoria das charneiras plásticas.

São abordadas, para cada um dos modelos estruturais propostos, questões relativas à distribuição das armaduras a aos valores de esforços solicitantes a considerar para o correto dimensionamento das lajes do pavimento. Apresentam-se, ainda, os detalhamentos das armaduras positivas e negativas resultantes das análises realizadas.

Palavras-chave: concreto armado; lajes; análise estrutural; modelos. 


\begin{abstract}
DUARTE, H. (1998). Aspects of the structural analysis of reinforced concrete building slabs. 84p. Dissertação (Mestrado) - Escola de Engenharia de São Carlos, Universidade de São Paulo.
\end{abstract}

The structural analysis of building pavements has been made through the use of very sophisticated instruments, with the dissemination of several softwares, characterized by pre- and post-processors which enable accurate analysis, considering the interaction between the stiffness of all the elements that constitute the pavement structural system. It is important to notice that even with the large number of available resources, simplified calculations cannot be disregarded in a designer's analysis, since they provide the confirmation of the results yielded by the software. So, this study presents some aspects of building slabs structural analysis, regarding concepts related to actions and constructive dispositions to be considered in such projects, to slabs pre-design and kinds of possible structural analysis.

Some structural models for linear analysis of building slabs are presented: (1) the simplified calculation through the use of tables of elastic method; (2) crossing beams analogy technique and (3) the finite element method, showing the characteristics of each one and defining up to what point each of them can be used safely, presenting coherent results to structural behavior.

In the elastic-plastic regime, a structural model of analysis through the yield line theory is presented.

For each proposed structural model, questions about arm distribution and values of requested efforts are considered, regarding the correct pavement slabs design. The details regarding positive and negative arms resulting from the analysis performed is also presented.

Keywords: reinforced concrete; slabs; structural analysis; models. 


\section{INTRODUÇÃO}

\subsection{APRESENTAÇĀO}

A análise estrutural de edificios vem se constituindo de recursos cada vez mais refinados nos últimos trinta anos, principalmente em função do acentuado desenvolvimento dos computadores ocorrido nesse período. Mais precisamente no que diz respeito às placas, que constituem o objeto das análises deste trabalho, importantes contribuições vêm sendo dadas através da aplicação do método dos elementos finitos. São inúmeras as referências desse assunto tanto no âmbito das análises elásticas lineares como das não lineares. BATOZ et al [1980] apresentam um estudo sobre alguns tipos de elementos finitos triangulares, com o propósito de identificar elementos com bom comportamento para análise de placas finas. Em BATOZ [1982], é apresentada explicitamente a formulação do elemento DKT (Discrete Kirchhoff Triangle), cujo desenvolvimento é baseado na aplicação simplificada das hipóteses de Kirchhoff sobre os lados do elemento, razendo deste um eficiente elemento triangular para análise de placas fletidas. No trabalho de ZIENKIEWICZ et al [1990], são desenvolvidos vários estudos sobre esse tipo de elemento. BERGAN \& WANG [1984] tratam de um elemento quadrilateral para placas fletidas com consideração, na sua formulação, até mesmo das deformações devidas ao esforço cortante. No campo das análises elásticas não-lineares, encontra-se a publicação de BATOZ \& DHATT [1981], em que é abordado um elemento quadrilateral conhecido por DKQ (Discrete Kirchhoff Quadrilateral), com formulação baseada numa generalização do elemento DKT e que está apresentada também em BATOZ \& TAHAR [1982]. Em CORREA [1991] são propostos aperfeiçoamentos para modelos usualmente empregados nos projetos de edifícios, como também o desenvolvimento de formulações de elementos para análise linear e não linear física de placas.

Em meio a essas contribuições efetivas ao desenvolvimento tecnológico das análises estruturais, o presente trabalho apresenta uma comparação de alguns métodos de análise de placas, mais precisamente de lajes de edifícios de concreto armado, adotando 
como exemplo um pavimento tipo de um edifício residencial. Procura abordar, no campo da teoria da elasticidade, desde os métodos mais simples de análise com o uso de tabelas em que as lajes são admitidas como isoladas umas das outras, até outros mais refinados com a consideração da interação das lajes com os demais elementos estruturais, como a técnica da analogia de grelha e o método dos elementos finitos. O cálculo através de tabelas é desenvolvido com a aplicação das tabelas encontradas em PINHEIRO [1986], que constituem uma adaptação das tabelas de BARES [1972]. A técnica da analogia de grelha é aplicada com base nas indicações do trabalho de BARBOZA [1992] e o método dos elementos finitos com a utilização do software SAP90, cujas instruções de uso podem ser encontradas em WILSON \& HABIBULLAH [1988]. As lajes do pavimento modelo são analisadas também através das hipóteses de cálculo em regime plástico com a teoria das channeiras plásticas. Contribuem para essa última análise, além das obras de LANGENDONCK $[1970,1975]$ e MONTOYA et al [1973], o trabalho de PINHEIRO [1988], que faz uma abordagem das análises elástica e plástica das lajes de edifícios e o de RIOS [1991], que apresenta uma implementação computacional para o cálculo de lajes retangulares através da associação do cálculo elástico com a teoria das charneiras plásticas.

\subsection{OBJETIVOS}

O presente trabalho tem por objetivo abordar alguns aspectos da análise estrutural das lajes de edifícios, reunindo tópicos teóricos e práticos dos métodos de análise mais comumente usados pelos projetistas de estruturas, bem como os apresentados como básicos nos cursos de engenharia. Não se tem a pretensão de apresentar um compêndio e nem de reunir prescrições de todas as normas existentes para projeto de edifícios. Procurase sim apresentar os conceitos básicos dos métodos de análise, tidos como indispensáveis a um calculista estrutural, principalmente quando se trata da utilização de um ou outro "software" como instrumento das análises. Para cada método estudado, são apresentados os resultados obtidos de sua aplicaçăo sobre a forma do pavimento tomado como exemplo, com o intuito de mostrar as particularidades de cada modelo e de indicar os casos em que cada um deles pode ser aplicado com segurança. Espera-se, assim, que este rrabalho constitua-se como material de apoio para alunos graduandos em engenharia civil, como também para eventuais consultas de projetistas em escritórios de cálculo estrutural. 


\subsection{DESCRIÇÃO SUSCINTA DO TRABALHO}

Apresentam-se, no capítulo 2, algumas considerações sobre as ações atuantes nas lajes de edifícios, suas definições pela NBR 8681 [1984], seus tipos e o modo como as mesmas são determinadas. São tratados alguns aspectos do pré-dimensionamento de lajes, de acordo com as indicações de espessuras mínimas e valores limites de deslocamentos encontrados no TEXTO BASE PARA REVISÃO DA NB-1 [1994]. Algumas disposições construtivas são abordadas visando à otimização e à padronização nos projetos, tendo-se por base os textos da NBR 6118 [1978] e o de PRELORENTZOU \& GIORGI [1994].

No capítulo 3, encontram-se definições básicas dos tipos de análise estrutural de placas, estabelecidas em função do comportamento que se admite para o concreto armado, abrangendo pois, desde conceitos de análise elástica linear, não linear, limite ou plástica, até análises através de modelos íisicos, de acordo com o elucidado no TEXTO BASE PARA REVISÃO DA NB-1 [1994].

Modelos estruturais para análise linear das lajes de edifícios, com uma descrição sucinta dos fundamentos teóricos relacionados com a formulação matemática de cada um deles, são apresentados no capítulo 4 , acompanhados dos resultados de sua aplicação sobre o pavimento tipo de um edifício residencial localizado na cidade de São Carlos, cujas características e forma estrutural encontram-se também neste referido capítulo. São feitas comparações entre os resultados das diversas análises, com o intuito de se avaliar até em que ponto uma ou outra análise apresentam valores de esforços solicitantes aceitáveis e seguros.

Um modelo estrutural para análise limite ou plástica de lajes, através da teoria das charneiras plásticas, é proposto no capítulo 5 , apresentando-se também princípios teóricos desse tipo de análise e sua aplicação sobre o pavimento tomado como modelo.

No capítulo 6 são abordados alguns aspectos teóricos e práticos para o detalhamento geral das armaduras do pavimento de um edifício. São apresentados para o pavimento tomado como modelo os detalhamentos das armaduras de cada um dos métodos de cálculo analisados no trabalho, mostrando as particularidades e considerações necessárias à correta armação segundo cada um deles. Os comentários finais e as conclusões, bem como as sugestões para novos trabalhos encontram-se no capítulo 7 . 


\section{AÇÕES, PRÉ-DIMENSIONAMENTO E DISPOSIÇÕES CONSTRUTIVAS A CONSIDERAR NOS PROJETOS DE EDIFICIOS}

\subsection{INTRODUÇÃO}

No presente capítulo são apresentadas considerações sobre as ações atuantes nas lajes de edificios, suas definições segundo a NBR 8681 [1984], seus tipos e o modo como as mesmas são determinadas segundo as prescrições da NBR 6120 [1980].

São tratados alguns aspectos do pré-dimensionamento de lajes, de acordo com indicações práticas do texto de CEOTTO [1985], em que é feito um estudo relacionando resistência e economia de material para os elementos estruturais que compõem um edifício. São apresentados os valores mínimos para as espessuras das lajes, visando a orientar o seu pré-dimensionamento e valores limites de deslocamentos, prescritos no TEXTO BASE PARA REVISẢO DA NB-1 [1994], para posteriores verificações.

Algumas disposições construtivas são estabelecidas visando à otimização e à padronização nos projetos, tomando como réeerência os textos da NBR 6118 [1978] e o de PRELORENTZOU \& GIORGI [1994].

\subsection{AÇÕES A CONSIDERAR NOS PROJETOS DE EDIFICIOS}

De acordo com a NBR 8681 [1984], as ações são definidas como sendo as causas que provocam o aparecimento de esforços ou def́ormações nas estruturas. Além disso, do ponto de vista prático, as forças e as deformações impostas pelas ações são consideradas como se fossem as próprias ações. É corrente a designação de ações indiretas para as deformações impostas e de ações diretas para as f́orças.

As ações que atuam nas estruturas podem ser subdivididas em ações permanentes, ações variáveis ou acidentais e ações excepcionais. 
As ações permanentes são aquelas que ocorrem nas estruturas com valores constantes ou de pequena variação em torno de sua média, durante praticamente toda a vida da construção. As ações permanentes podem ser diretas ou indiretas. As diretas são aquelas oriundas dos pesos próprios dos elementos da estrutura, de dispositivos construtivos permanentes, de pesos de equipamentos fixos e de empuxos devidos ao peso próprio de terras não removiveis aplicados sobre a estrutura. As indiretas podem ser consideradas como sendo as forças de protensão em peças de concreto protendido, os recalques de apoio devidos a deslocamentos dos elementos estruturais ou deformabilidade dos solos das fundações e a retração dos materiais.

As ações variáveis såo as que ocorrem nas estruturas com valores que apresentam variações significativas em torno de sua média, durante a vida da construção. São as cargas de uso das construções (pessoas, móveis, materiais diversos), bem como seus efeitos (forças de frenação, de impacio e centrífugas), efeitos do vento, das variações de temperatura, do atrito nos aparelhos de apoio e das pressões hidrostáticas e hidrodinâmicas. Em função da probabilidade de ocorrência, as ações variáveis são classificadas em normais e especiais. As normais são aquelas com probabilidade de ocorrência suficientemente grande, de tal maneira que sejam obrigatoriamente consideradas no projeto estrutural. Incluem-se nessa classificação as chamadas cargas acidentais que atuam nas estruturas dos edifícios, mais precisamente sobre as lajes, devidas a pessoas, mobiliário, veículos, bibliotecas, entre outras. São consideradas especiais as açôes sísmicas e as cargas acidentais de intensidade especiais, como, por exemplo, as provenientes de veículos transportando equipamentos especííicos com pesos acima daqueles admitidos como padrões.

As açōes excepcionais são aquelas que têm duração extremamente curta e muito baixa probabilidade de ocorrência durante a vida da construção, mas que devem ser consideradas nos projetos de determinadas estruturas. São as ações decorrentes de causas como: explosões, choques de veículos, incêndios, enchentes ou sismos excepcionais.

Os valores numéricos a serem admitidos para cada tipo de ação acima citados, podem ser encontrados na NBR 6120 [1980]. Apresentam-se, entretanto, no presente trabalho, alguns destes valores relacionados com a estimativa das ações permanentes diretas e variáveis normais para os projetos usuais de edifícios. Na TABELA 2.1, encontram-se os pesos especificos aparentes dos materiais de construçăo e componentes de edificações mais comumente empregados nos projetos, que devem ser considerados quando não houver uma determinação experimental para os mesmos.

Tendo em vista que a maioria das ações nos edifícios são provenientes de elementos com distribuição geométrica plana, sejam estes paredes, coberturas, forros, 
caixilhos, pisos e revestimentos, apresentam-se na TABELA 2.2 alguns valores de ações por unidade de área para alguns tipos dos referidos elementos, de acordo com o apresentado no trabalho de GIONGO [1994]. Nas ações devidas às paredes, estão incluídas as relativas aos pesos das argamassas de assentamento $(1 \mathrm{~cm})$ e de revestimento $(1,5 \mathrm{~cm}$ em cada face). Para as ações resultantes das coberturas, são consideradas as massas das telhas úmidas.

TABELA 2.1 - Valores dos pesos específicos aparentes dos materiais de construção

\begin{tabular}{|c|c|c|}
\hline & Materiais & $\begin{array}{c}\text { Peso específico } \\
\text { aparente } \\
\left(\mathrm{kN} / \mathrm{m}^{3}\right)\end{array}$ \\
\hline \multirow{5}{*}{ Rochas } & Arenito & 26 \\
\hline & Basalto & 30 \\
\hline & Gneisse & 30 \\
\hline & Granito & 28 \\
\hline & Mármore e Calcário & 28 \\
\hline \multirow{6}{*}{$\begin{array}{l}\text { Blocos } \\
\text { Artificiais }\end{array}$} & Blocos de argamassa & 22 \\
\hline & Cimento amianto & 20 \\
\hline & Lajotas cerâmicas & 18 \\
\hline & Tijolos furados & 13 \\
\hline & Tijolos maciços & 18 \\
\hline & Tijolos sílico-calcários & 20 \\
\hline \multirow{5}{*}{$\begin{array}{l}\text { Revestimentos } \\
\text { e Concretos }\end{array}$} & Argamassa de cal, cimento/areia & 19 \\
\hline & Argamassa de cimento e areia & 21 \\
\hline & Argamassade gesso & 12,5 \\
\hline & Concreto simples & 24 \\
\hline & Concreto armado & 25 \\
\hline \multirow{4}{*}{ Madeiras } & Pinho, cedro & 5 \\
\hline & Louro, imbuia, pau óleo & 6,5 \\
\hline & Guajuvirá, guatambu, grápia & 8 \\
\hline & Angico, cabriuva, ipê róseo & 10 \\
\hline \multirow{9}{*}{ Metais } & Aço & 78,5 \\
\hline & Alumínio e ligas & 28 \\
\hline & Bronze & 85 \\
\hline & Chumbo & 114 \\
\hline & Cobre & 89 \\
\hline & Ferro fundido & 72,5 \\
\hline & Estanho & 74 \\
\hline & Latão & 85 \\
\hline & Zinco & 72 \\
\hline \multirow{6}{*}{$\begin{array}{l}\text { Materiais } \\
\text { diversos }\end{array}$} & Alcatrão & 12 \\
\hline & Asfalto & 13 \\
\hline & Borracha & 17 \\
\hline & Papel & 15 \\
\hline & Plástico em folhas & 21 \\
\hline & Vidro plano & 26 \\
\hline
\end{tabular}


TABELA 2.2 - Ações permanentes por unidade de área

\begin{tabular}{|c|l|c|}
\hline \multirow{2}{*}{ Item } & \multicolumn{1}{|c|}{ Material } & Ação $\left(\mathrm{kN} / \mathrm{m}^{2}\right)$ \\
\hline \multirow{5}{*}{ Paredes } & $1 / 2$ tijolo maciço & 2,50 \\
& 1 tijolo maciço & 4,00 \\
& $1 / 2$ tijolo furado (baiano) & 2,20 \\
& 1 tijolo furado & 3,20 \\
& Bloco de concreto (espessura de 10 cm) & 2,20 \\
& Bloco de concreto (espessura de $20 \mathrm{~cm})$ & 3,50 \\
& Bloco de concreto celular (espessura de 10 cm) & 0,50 \\
& Bloco de concreto celular (espessura de 20 cm) & 0,80 \\
\hline \multirow{3}{*}{ Coberturas } & Com telhas cerâmicas, com madeiramento & 1,20 \\
& Com telhas de fibrocimento, com madeiramento & 0,40 \\
& Com telhas de alumínio e estrutura de aço & 0,30 \\
& Com telhas de alumínio e estrutura de alumínio & 0,20 \\
\hline Forros & Com painéis de gesso, com estrutura de madeira e aço & 0,50 \\
& Com blocos sólidos de gesso & 0,70 \\
\hline Caixilhos & Com estrutura de alumínio e vidros & 0,20 \\
& Com estrutura de aço e vidros & 0,30 \\
\hline Telhas & De fibrocimento tipo Canalete 43 & 0,28 \\
& De fibrocimento tipo Canalete 90 & 0,25 \\
\hline
\end{tabular}

Ao se definir a forma estrutural do pavimento de um edifício, pode acontecer que não resultem vigas sob todas as linhas de ocorrência de paredes a que estas estejam atuando diretamente sobre as próprias lajes. Neste caso, é possível a consideração simplificada de tais ações como uniformemente distribuídas sobre toda a laje, ressaltandose que este não é o melhor procedimento a ser adotado, conforme abordado mais adiante no trabalho, tendo em vista a disponibilidade atual de recursos numéricos para análises mais precisas. Com relação à ação de paredes divisórias, que não tenham sua posição definida no projeto arquitếônico, a NBR 6120 [1980] estabelece que para o cálculo de tais lajes seja considerado, além dos demais carregamentos já previstos, um outro uniformemente distribuído por metro quadrado de piso, não menor que um terço do peso por metro linear da parede pronta, observado o valor mínimo de $1 \mathrm{kN} / \mathrm{m}^{2}$. 
As ações variáveis normais são consideradas atuando no piso das edificações, isto é, nos elementos estruturais planos ou lajes, sendo supostas uniformemente distribuídas sobre os mesmos, com seus valores mínimos indicados pela NBR 6120 [1980]. A TABELA 2.3 apresenta alguns destes valores para determinados ambientes arquitetônicos.

TABELA 2.3 - Valores mínimos das ações variáveis normais

\begin{tabular}{|c|c|c|}
\hline & Ambiente Arquitetônico & Ação $\left(\mathrm{kN} / \mathrm{m}^{2}\right)$ \\
\hline Casa de Máquinas & $\begin{array}{l}\text { (incluindo a massa das máquinas) a ser } \\
\text { determinada em cada caso, porém com } \\
\text { o valor mínimo de }\end{array}$ & 7,50 \\
\hline Corredores & $\begin{array}{l}\text { Com acesso ao público } \\
\text { Sem acesso ao público }\end{array}$ & $\begin{array}{l}3,00 \\
2,00\end{array}$ \\
\hline Edifícios Residenciais & $\begin{array}{l}\text { Dormitórios, sala, copa, cozinha e banheiro } \\
\text { Despensa, área de serviço e lavanderia }\end{array}$ & $\begin{array}{l}1,50 \\
2,00\end{array}$ \\
\hline Escadas & $\begin{array}{l}\text { Com acesso ao público } \\
\text { Sem acesso ao público }\end{array}$ & $\begin{array}{l}3,00 \\
2,50\end{array}$ \\
\hline Forros & Sem acesso a pessoas & 0,50 \\
\hline $\begin{array}{c}\text { Garagens } \\
\text { e Estacionamentos }\end{array}$ & $\begin{array}{l}\text { Para veículos de passageiros ou semelhantes } \\
\text { com carga máxima de } 25 \mathrm{kN} \text { por veículo }\end{array}$ & 3,00 \\
\hline Terraços & $\begin{array}{l}\text { Sem acesso ao público } \\
\text { Com acesso ao público } \\
\text { Inacessível a pessoas }\end{array}$ & $\begin{array}{l}2,00 \\
3,00 \\
0,50\end{array}$ \\
\hline Vestíbulo & $\begin{array}{l}\text { Sem acesso ao público } \\
\text { Com acesso ao público }\end{array}$ & $\begin{array}{l}1,50 \\
3,00\end{array}$ \\
\hline Escrtiórios & $\begin{array}{l}\text { Salas de uso geral e banheiro } \\
\text { Anfiteatro com assentos fixos, corredor e }\end{array}$ & 2,00 \\
\hline Escolas & $\begin{array}{l}\text { sala de aula } \\
\text { Ouirras salas }\end{array}$ & $\begin{array}{l}3,00 \\
2,00\end{array}$ \\
\hline Galerias de Arte & $\begin{array}{l}\text { A ser determinada em cada caso, porém } \\
\text { com o mínimo de }\end{array}$ & 3,00 \\
\hline Galerias de Lojas & $\begin{array}{l}\text { A ser determinada em cada caso, porém } \\
\text { com o mínimo de }\end{array}$ & 3,00 \\
\hline Ginásio de Esportes & & 5,00 \\
\hline
\end{tabular}


A NBR 6120 [1980] prescreve ainda que, nos compartimentos destinados a carregamentos especiais, como os devidos a arquivos, depósitos de materiais, máquinas leves, caixas-forte e outros, não é necessária uma verificação mais exata destes carregamentos, desde que se considere um acréscimo de $3 \mathrm{kN} / \mathrm{m}^{2}$ no valor da carga acidental.

No caso de balcões e sacadas com acesso ao público devem ser previstas a mesma ação uniformemente distribuida do elemento estrutural com o qual se comunicam e , ainda, uma ação horizontal de $0,8 \mathrm{kN} / \mathrm{m}$ na altura do corrimão e uma ação vertical mínima de $2 \mathrm{kN} / \mathrm{m}$, sendo estas duas últimas cargas válidas também para os parapeitos.

Para as escadas constituídas de degraus isolados, considera-se uma ação concentrada de $2,5 \mathrm{kN}$ aplicada na posição mais desfavorável dos mesmos. Esta ação não deve ser incluída na composição de ações para as vigas que suportam os degraus.

Nos casos de edifícios com garagens em pavimentos térreos ou outros pavimentos, a NBR 6120 [1980] estabelece que há necessidade de se considerar a ação de veículos conforme indicado na TABELA 2.3, com majoração da mesma por um coeficiente $\varphi$ determinado do seguinte modo:

$$
\begin{array}{ll}
\varphi=1,00 & \text { quando } \ell \geq \ell_{0} \\
\varphi=\ell_{0} / \ell \leq 1,43 & \text { quando } \ell<\ell_{0}
\end{array}
$$

sendo $\ell$ o vão de uma viga ou o menor vão de uma laje em análise no referido pavimenio; $\ell_{0}$ $=3 \mathrm{~m}$ para o caso das lajes $\mathrm{e} \ell_{0}=5 \mathrm{~m}$ para o caso das vigas. Ressalta-se que esta majoração deve ser feita apenas para a análise de vigas e lajes e não de pilares ou paredes.

\subsection{PRÉ-DIMENSIONAMENTO}

Para efeito de análise econômica, quanto mais esbelta for uma laje, ou seja, quanto menor for sua espessura, mais viável ela será. Existem, no entanto, valores limites estabelecidos pelos estados limites último e de utilização do elemento estrutural. E embora seja possivel executar lajes com pequena espessura, que satisfaça aos limites indicados, o desconî́orto para o usuário é sensivel ao se caminhar sobre elas. A vibração pode vir a 
tornar-se um estado limite de utilização, apesar deste não ser um caso explicitamente indicado por norma.

Alguns critérios práticos podem ser estabelecidos com a finalidade de orientar o prédimensionamento das lajes de edifícios. CEOTTO [1985], apresenta um estudo sobre o assunto, relacionando os parâmetros de resistência estrutural com os economia de material e estabelecendo assim critérios para um bom dimensionamento dos elementos estruturais.

Se a laje for armada em duas direções, isto é, se tiver a relação entre os vãos teóricos maior e menor inferior a 2, a espessura da laje pode ser adotada entre os limites de um cinqüenta avos (1/50) e um quarenta avos (1/40) do vão teórico menor. Para as lajes armadas em uma direção, esses limites se modificam para um quarenta e cinco avos (1/45) e um trinta avos (1/30) do menor vão.

Os vãos considerados econômicos podem ser adotados em torno de $4 \mathrm{~m}$, resultando áreas aproximadas de $15 \mathrm{~m}^{2}$ a $20 \mathrm{~m}^{2}$.

As taxas de armadura devem resultar entre 2,4 a $3,2 \mathrm{~kg} / \mathrm{m}^{2}$ ou 28 a $53 \mathrm{~kg} / \mathrm{m}^{3}$ de laje, apresentando pequenas variações para distintos valores da resistência característica do concreto.

O pré-dimensionamento das lajes usuais dos edifícios pode ser íeito ainda com o auxílio de algumas fórmulas simplificadoras que levam em conta os valores limites para dimensões, deslocamentos e abertura de fissuras das mesmas, estabelecidas por normas ou manuais de concreto armado, como, por exemplo, as encontradas na NBR 6118 [1978], Manual do "American Concrete Institute - ACI" [1985] e Código Modelo do "Comitê EuroInternational du Beton - CEB-FIP" [1978]. Neste trabalho, entretanto, opta-se pelo que é normalmente feito pelos projetistas, a saber, um pré-dimensionamento feito diretamente em função de sua experiência e da comparação com outros projetos já realizados, atentando-se para os referidos valores limites estabelecidos pelas respectivas normas técnicas do assunto e para os critérios práticos anteriormente apresentados. Assim sendo, apresentamse, a seguir, alguns valores limites que estão indicados no TEXTO BASE PARA REVISÃO DA NB-1 [1994].

Os valores limites mínimos para as espessuras das lajes são:

a) Lajes maciças:

a.1) $5 \mathrm{~cm}$ para lajes de cobertura;

a.2) $7 \mathrm{~cm}$ para lajes de piso;

a.3) $10 \mathrm{~cm}$ para lajes que suportern veículos de peso total $\leq 30 \mathrm{kN}$;

a.4) $12 \mathrm{~cm}$ para lajes que suportem veículos de peso total $>30 \mathrm{kN}$. 
b) Lajes nervuradas:

b.1) A espessura da mesa não deve ser menor que $4 \mathrm{~cm}$ e $1 / 15$ da distância entre nervuras;

b.2) A espessura das nervuras não deve ser menor que $4 \mathrm{~cm}$ e $1 / 5$ de sua altura.

Com relação aos deslocamentos limites, o TEXTO BASE PARA REVISÃO DA NB-1 [1994] os define como sendo valores práticos utilizados para a verificação do estado limite de deformações excessivas da estrutura. Os valores desses deslocamentos, adaptados do referido texio para a análise de pavimentos de edif́ícios, encontram-se na TABELA 2.4, atendendo às seguintes observações gerais:

a) Todos os valores limites de deslocamentos supõem elementos suporlados em suas extremidades por apoios que não se movem;

b) L é o menor vão teórico das lajes, exceto em casos de verificação de paredes e divisórias, onde interessa a direção na qual a parede ou divisória se desenvolve. Quando se tratar de balanços, o vão a ser considerado deve ser o dobro do comprimento do balanço;

c) Deslocamento total é a soma de todos os deslocamentos individualmente computados para todas as ações, mais os efeitos dependentes do tempo, quando se fizerem presentes;

d) Deslocamentos excessivos podem ser parcialmente compensados por contraflechas.

(1) As superficies devem ser suficientemente inclinadas ou o deslocamento previsto compensado por contraflechas, de modo a năo se ter acúmulo de água.

(2) Os deslocamentos podem ser parcialmente compensados pela especificação de contraflechas. Entretanto, nenhum deslocamento incremental, nem a atuação isolada da contraflecha, podem ocasionar um desvio do plano maior que L/350.

(3) $O$ vão $L$ deve ser tomado na direção na qual a parede ou a divisória se desenvolve. 
(4) Rotação nos elementos que suportam paredes. Equivale a 1/600 da altura da parede.

TABELA 2.4 - Valores limites para deslocamentos

\begin{tabular}{|c|c|c|c|c|}
\hline Critérios & $\begin{array}{l}\text { Razões } \\
\text { da } \\
\text { limitação }\end{array}$ & Exemplos & $\begin{array}{l}\text { Deslocamentos } \\
\text { limites }\end{array}$ & $\begin{array}{c}\text { Deslocamento } \\
\text { a } \\
\text { considerar }\end{array}$ \\
\hline $\begin{array}{l}\text { Aceitabilidade } \\
\text { Sensorial }\end{array}$ & Visual & $\begin{array}{l}\text { Deslocamentos em } \\
\text { elementos estrutu- } \\
\text { rais visíveis }\end{array}$ & $\mathrm{L} / 250$ & $\begin{array}{c}\text { Deslocamento } \\
\text { total }\end{array}$ \\
\hline \multirow{2}{*}{$\begin{array}{l}\text { Estrutura } \\
\text { em } \\
\text { serviço }\end{array}$} & $\begin{array}{c}\text { Superfícies que } \\
\text { devem drenar } \\
\text { água }\end{array}$ & $\begin{array}{c}\text { Coberturas } \\
e \\
\text { Varandas }\end{array}$ & $\mathrm{L} / 250(1)$ & $\begin{array}{c}\text { Deslocamento } \\
\text { total }\end{array}$ \\
\hline & $\begin{array}{c}\text { Pavimentos que } \\
\text { devem perma- } \\
\text { necer planos }\end{array}$ & $\begin{array}{c}\text { Ginásíos } \\
\text { e } \\
\text { Pistas de Boliche }\end{array}$ & $\begin{array}{l}\text { L/350 mais } \\
\text { contraflecha } \\
\text { ou L/600 (2) }\end{array}$ & $\begin{array}{c}\text { Deslocamento } \\
\text { total }\end{array}$ \\
\hline \multirow{4}{*}{$\begin{array}{c}\text { Efeitos em } \\
\text { elementos } \\
\text { não estruturais }\end{array}$} & \multirow[t]{2}{*}{ Paredes } & $\begin{array}{c}\text { Alvenaria, caixilhos } \\
\text { e revestimentos }\end{array}$ & $\begin{array}{c}L / 500(3) \text { ou } \\
10 \mathrm{~mm} \mathrm{ou} \\
f=0,0017 \mathrm{rad}(4)\end{array}$ & $\begin{array}{l}\text { Deslocamentos } \\
\text { ocorridos após a } \\
\text { construção da } \\
\text { parede }\end{array}$ \\
\hline & & $\begin{array}{c}\text { Divisórias leves e } \\
\text { Caixilhos telescó- } \\
\text { picos }\end{array}$ & $\begin{array}{l}\text { L/250 (3) ou } \\
25 \mathrm{~mm}\end{array}$ & $\begin{array}{c}\text { Deslocamentos } \\
\text { ocorridos após a } \\
\text { instalação da } \\
\text { divisória }\end{array}$ \\
\hline & \multirow[t]{2}{*}{ Forros } & $\begin{array}{l}\text { Revestimentos } \\
\text { colados }\end{array}$ & $L / 360$ & $\begin{array}{c}\text { Deslocamentos } \\
\text { ocorridos após a } \\
\text { construção do } \\
\text { forro }\end{array}$ \\
\hline & & $\begin{array}{l}\text { Revestimentos } \\
\text { pendurados ou } \\
\text { com juntas }\end{array}$ & $L / 180$ & $\begin{array}{l}\text { Deslocamentos } \\
\text { ocorridos após a } \\
\text { construção do } \\
\text { forro }\end{array}$ \\
\hline
\end{tabular}




\subsection{DISPOSIÇÕES CONSTRUTIVAS}

Visando a otimizar, uniformizar e padronizar os procedimentos de elaboração de projetos bem como de sua execução, determinadas empresas de engenharia estabelecem normas para serem seguidas em suas obras, normas estas que abrangem desde critérios e parâmetros para projeto como disposições construtivas a serem especificadas pelos mesmos. Embora sendo indicadas mais restritamente às empresas que as estabelecem, tais disposições são importantes e colaboram para a engenharia civil do país, tendo-se em vista a experiência de tais empresas na área de construção. Apresentam-se, a seguir, alguns tipos destas disposições estabelecidas para as lajes dos edifícios usuais, conforme constam no trabalho de PRELORENTZOU \& GIORGI [1994], na NBR 6118 [1978] e no texto base para sua revisão [1994]:

a) As espessuras das lajes devem ser uniformizadas ao longo do pavimento do edifício, sendo desaconselhável um número de espessuras maior que 2; (PRELORENTZOU \& GIORGI [1994])

b) As bordas das lajes em balanço devem ter uma viga de contomo para enrijecimento e ancoragem da impermeabilização; (PRELORENTZOU \& GIORGI [1994])

c) Devem ser evitados rebaixos nas lajes, exceto nos casos de detalhe arquitetônico; (PRELORENTZOU \& GIORGI [1994])

d) Armaduras minimas: (TEXTO BASE PARA REVISÃO DA NB-1 [1994])

As armaduras positivas das duas direções de lajes armadas preponderantemente nas duas direções, deverão obedecer (sendo $b=100 \mathrm{~cm}$ e d a altura útil da laje $\mathrm{em} \mathrm{cm}$ ) ao mínimo dado por:

$$
\begin{aligned}
& \left.A_{s, \min }=0,12 \% \text {.b.d para aços CA-50 e CA-60 (cm } 2 / m\right) \\
& A_{s, m i n}=0,25 \% \text { b.d para aços CA-25 (cm²/m) }
\end{aligned}
$$

Nas lajes armadas preponderantemente em uma direção os mínimos serão dados por:

Armadura da direçåo principal:

$A_{s, m i n}=0,15 \%$ b.d para aços CA-50 e CA-60 (cm²/m) 
Armadura da direção secundária:

$$
\begin{aligned}
A_{\mathrm{s}, \min }>\quad & 0,10 \% . \text { b.d } \quad\left(\mathrm{cm}^{2} / \mathrm{m}\right) \\
& 20 \% \text { da armadura principal } \quad\left(\mathrm{cm}^{2} / \mathrm{m}\right) \\
& 0,9 \mathrm{~cm}^{2} / \mathrm{m}
\end{aligned}
$$

As armaduras negativas terão como mínimo:

$$
\begin{aligned}
& A_{s, \text { min }}=0,15 \% \text { b.d para aços CA-50 e CA-60 (cm²/m) } \\
& \left.A_{s, \text { min }}=0,25 \% \text {.b.d para aços CA-25 (cm } / \mathrm{m}\right)
\end{aligned}
$$

As armaduras de tração e compressão de lajes terão como máximo o valor de $4 \%$ da respectiva área de concreto onde vão atuar.

e) Diâmetros $(\phi)$ recomendados para as barras das armaduras: (PRELORENTZOU \& GIORGI [1994])

- Aço CA 60:| $\mid \begin{aligned} & \phi 5,0 \mathrm{~mm} ; \\ & \phi 4,2 \mathrm{~mm} \text { (só para distribuição); }\end{aligned}$

- Aço CA 50: $\phi 6,3 ; \phi 8,0 ; \phi 10 \mathrm{~mm}$;

- Para armaduras negativas não utilizar $\phi 5,0 \mathrm{~mm}$;

- Não utilizar diâmetros que excedam 1/10 da espessura da laje; (NBR $6118[1978])$

f) Espaçamento das barras: (NBR 6118 [1978])

- Na região dos maiores momentos nos vãos das lajes, o espaçamento das barras da armadura principal não deve ser maior que $20 \mathrm{~cm}$. Nas lajes armadas numa única direção, esse espaçamento nåo deve, também, ser maior que duas vezes a espessura (2h);

- Os estribos nas lajes nervuradas, sempre que necessários, não devem ter espaçamento maior que $20 \mathrm{~cm}$;

- O espaçamento das barras de distribuição não deve ser maior que $33 \mathrm{~cm}$. 
g) No detalhamento das armaduras, verificar sempre a possibilidade de uniformizar os comprimentos das barras longitudinais, ou seja, diminuir ao máximo o número de posições ou tipos de barras; (PRELORENTZOU \& GIORGI [1994])

h) A extensão dos apoios extremos de uma laje, sobre alvenaria, não deve ser menor que sua espessura no meio do vão, nem inferior a 7 cm; (NBR 6118 [1978])

i) Aberturas: (NBR 6118 [1978])

Quando forem previstas aberturas nas lajes, deve-se verificar o seu efeito na resistência e na deformação de modo que não sejam ultrapassados os limites exigidos pela referida norma. Esta verificação poderá ser dispensada nos seguintes casos:

- aberturas normais ao plano médio das lajes armadas numa só direção, se na direção perpendicular à armadura principal a maior dimensão da abertura não ultrapassar 1/10 da largura útil e nem 1/10 do vão, não havendo entre duas aberturas consecutivas distância inferior a 1/2 do vão e entre uma abertura e a borda livre das laje distância inferior a 1/4 do vão;

- aberturas normais ao plano médio das lajes armadas em cruz, se a dimensão da abertura em cada direção da armadura năo ultrapassar $1 / 10$ do menor vão $e$ na̋o houver entre duas aberturas distância inferior a 1/2 do vão e entre uma abertura e a borda livre da laje distância inferior a 1/4 do vão;

- aberturas paralelas ao plano médio das lajes, se a sua maior dimensão transversal for inferior a $1 / 3$ da espessura da laje e o espaçamento entre duas aberturas consecutivas de centro a centro for superior a 4 vezes aquela maior dimensão.

j) Cobrimento: (NBR 6118 [1978])

Qualquer barra das armaduras de uma laje, até mesmo de distribuição, deve ter cobrimento de concreto pelo menos igual ao seu diâmetro e não menor que

- Para concreto revestido com argamassa de espessura mínima de $1 \mathrm{~cm}$

$0,5 \mathrm{~cm}$ em lajes no interior de edifícios

$1,5 \mathrm{~cm}$ em lajes e paredes ao ar livre

- Para concreto aparente:

$2,0 \mathrm{~cm}$ no interior de edifícios

$2,5 \mathrm{~cm}$ ao ar livre 


\subsection{CONSIDERAÇÕES FINAIS}

Algumas informações apresentadas neste capítulo, principalmente no que diz respeito ao pré-dimensionamento e às disposições construtivas a considerar nos projetos de edifícios, não constituem indicações das normas técnicas da área. Entretanto, foram apresentadas em caráter sugestivo, tendo em vista a experiência de seus respectivos autores. Com relação às prescrições das normas técnicas apresentadas, ressalta-se que foram transcritas com o intuito de reunir as mais diretamente relacionadas com o dimensionamento das lajes de edifícios, visando a facilitar sua aplicação tanto neste trabalho como também em outros projetos. 


\section{TIPOS DE ANÁLISE ESTRUTURAL E SEUS FUNDAMENTOS TEÓRICOS PARA OS ELEMENTOS DE PLACA}

\subsection{INTRODUÇÃO}

A análise estrutural tem por objetivo determinar os efeitos das ações em uma estrutura, com a finalidade de efetuar verificações de estados limites últimos e de utilização, segundo definições do TEXTO BASE PARA REVISÃO DA NB1 [1994]. Através da análise estrutural, torna-se possivel estabelecer as distribuições de esforços internos, tensões, deformações e deslocamentos, em uma parte ou em toda a estrutura. Deve ser realizada através de um modelo estrutural que represente, da maneira mais adequada possivel, o comportamento da estrutura real, permitindo delinear assim o caminhamento das tensőes até os apoios da mesma. Em casos muito complexos, a interação solo-estrutura também deve ser contemplada no modelo.

As estruturas usuais de edifícios podem ser idealizadas, ao serem submetidas à análise, como sendo uma composição de elementos estruturais básicos, classificados de acordo com sua forma geométrica e sua função estrutural. O presente trabalho tem por objeto de análise os elementos de superfície, que são aqueles em que a menor dimensão, usualmente chamada espessura, não supera a quarta parte do menor vão. Concentra-se a atenção, aqui, mais precisamente nos elementos designados por placas, que são elementos de superfície plana sujeitos principalmente a ações normais ao seu plano médio. As placas de concreto armado são normalmente conhecidas com o nome de lajes.

Os elementos de placa podem ser analisados admitindo-se que são válidas as seguintes hipóteses básicas:

a) As seçōes planas permanecem planas após as deformações;

b) Os elementos podem ser representados por seu plano médio. 
Em função do nível de solicitação que se esteja submetendo o concreto armado e dos respectivos valores das tensões de compressão observados, a análise estrutural das lajes pode ser efetuada, conforme consta no TEXTO BASE PARA REVISÃO DA NB1 [1994], através de cada um dos tipos de análise apresentados abaixo.

\subsection{ANÁLISE LINEAR}

Admite-se o comportamento elástico-linear para o concreto armado. É aplicável, segundo indicações do TEXTO BASE PARA REVISÃO DA NB-1 [1994], quando se tem um nível de solicitação que produz tensões de compressão que não superam $50 \%$ da resistência característica $\left(f_{\mathrm{ck}}\right)$ do mesmo. As características geométricas podem ser determinadas pelas seções brutas das lajes, e o módulo de elasticidade e o coeficiente de Poisson adotados de acordo com os valores prescritos pelo texto acima citado.

A análise linear fornece resultados que normalmente são usados para a verificação dos Estados Limites de Utilizaçăo. Para a grande maioria das estruturas de concreto armado, no entanto, é possível estender tais resultados, com razoável segurança, para verificações aproximadas de Estado Limite Último, mesmo com altas tensões, desde que se observem a ductilidade em determinadas seções críticas sujeitas a maiores rotações.

Para a verificação do Estado Limite de Deformação Excessiva, é permitido utilizar valores de rigidez do Estádio I para os elementos estruturais, com o valor secante (Ec) do módulo de elasticidade longitudinal do concreto, considerando-se os efeitos da deformação lenta aưravés da mulkiplicação do valor da flecha imediata pela relação entre a curvatura final e a curvatura inicial na seção de maior momento fletor absoluto. Estes valores podem ser calculados através de:

$$
(1 / r)_{\text {inicial }}=\left(\varepsilon_{\mathrm{c}}+\varepsilon_{\mathrm{s}}\right) / \mathrm{d} \quad(1 / \mathrm{r})_{\text {final }}=\left(\beta_{\mathrm{c} .} \varepsilon_{\mathrm{c}}+\varepsilon_{\mathrm{s}}\right) / \mathrm{d}
$$

sendo $\varepsilon_{\mathrm{c}}$ o encurtamento máximo do concreto correspondente à situação inicial e $\varepsilon_{\mathrm{s}} 0$ alongamento da armadura de tração, na situação inicial. $O$ coeficiente $\beta_{\mathrm{c}}$ será tomado igual a 3 se as ações de longa duração forem colocadas logo após o descimbramento, e igual a 2 se colocadas somente seis meses após a concretagem. 


\subsubsection{Fundamentos teóricos da análise linear dos elementos de placa}

A análise linear dos elementos de placa é feita com base na teoria clássica de Kirchhoff para placas delgadas. Tal teoria interpreta suficientemente bem o comportamento de placas que apresentam a relação espessura/menor vão entre $1 / 5$ e 1/100. As lajes usuais dos edifícios possuem esta relação entre $1 / 40$ e 1/60, atingindo até $1 / 80$. A hipótese clássica de Kirchhoff para placas finas estabelece que "pontos situados sobre retas originalmente normais à superfície média indeformada, permanecem sobre retas normais à superfície média deformada". Admite-se, pois, que os pontos do plano médio da placa sofrem apenas deslocamentos verticais, pequenos em relação à espessura da mesma, desprezando-se os deslocamentos horizontais.

Além da hipótese clássica de Kirchhoff, as demais hipóteses admitidas para a aplicação da teoria clássica da elasticidade de placas são que as mesmas são constituídas de material homogêneo e isótropo, com comportamento elástico-linear sob variadas ações, ou seja, com capacidade de retomar suas formas iniciais quando tais ações deixam de atuar, estando assim sujeitas à Lei de Hooke.

$\mathrm{Na}$ formulação matemática da teoria, é admitida uma carga $p(x, y)$, normal ao plano da placa, que pode ser distribuída por qualquer lei, sobre toda ou parte da placa. A deformada da placa é definida por uma função $w(x, y)$, que determina os deslocamentos verticais dos pontos $(x, y)$ do plano médio da mesma. Os esforços solicitantes que atuam sobre um elemento de placa são mostrados na FIGURA 3.1, com

$$
\begin{array}{cc}
v_{x}=\int_{-h / 2}^{h / 2} \tau_{x z} \cdot d z & v_{y}=\int_{-h / 2}^{h / 2} \tau_{y z} \cdot d z \\
m_{x}=\int_{-h / 2}^{h / 2} \sigma_{x} \cdot z \cdot d z & m_{y}=\int_{-h / 2}^{h / 2} \sigma_{y} \cdot z \cdot d z \\
m_{y x}=-m_{x y}=\int_{-h / 2}^{h / 2} \tau_{x y} \cdot z \cdot d z &
\end{array}
$$

sendo

$v_{x}=$ força cortante por unidade de comprimento da seção da placa perpendicular ao eixo $\mathrm{x}$;

$v_{y}=$ força cortante por unidade de comprimento da seção da placa perpendicular ao eixo y; 
$m_{x}=$ momento fletor por unidade de comprimento da seção da placa perpendicular ao eixo $x$ (em torno do eixo $y)$;

$m_{y}=$ momento fletor por unidade de comprimento da seção da placa perpendicular ao eixo $y$ (em torno do eixo $x$ );

$m_{y x}=$ momento volvente (ou de torção) por unidade de comprimento.

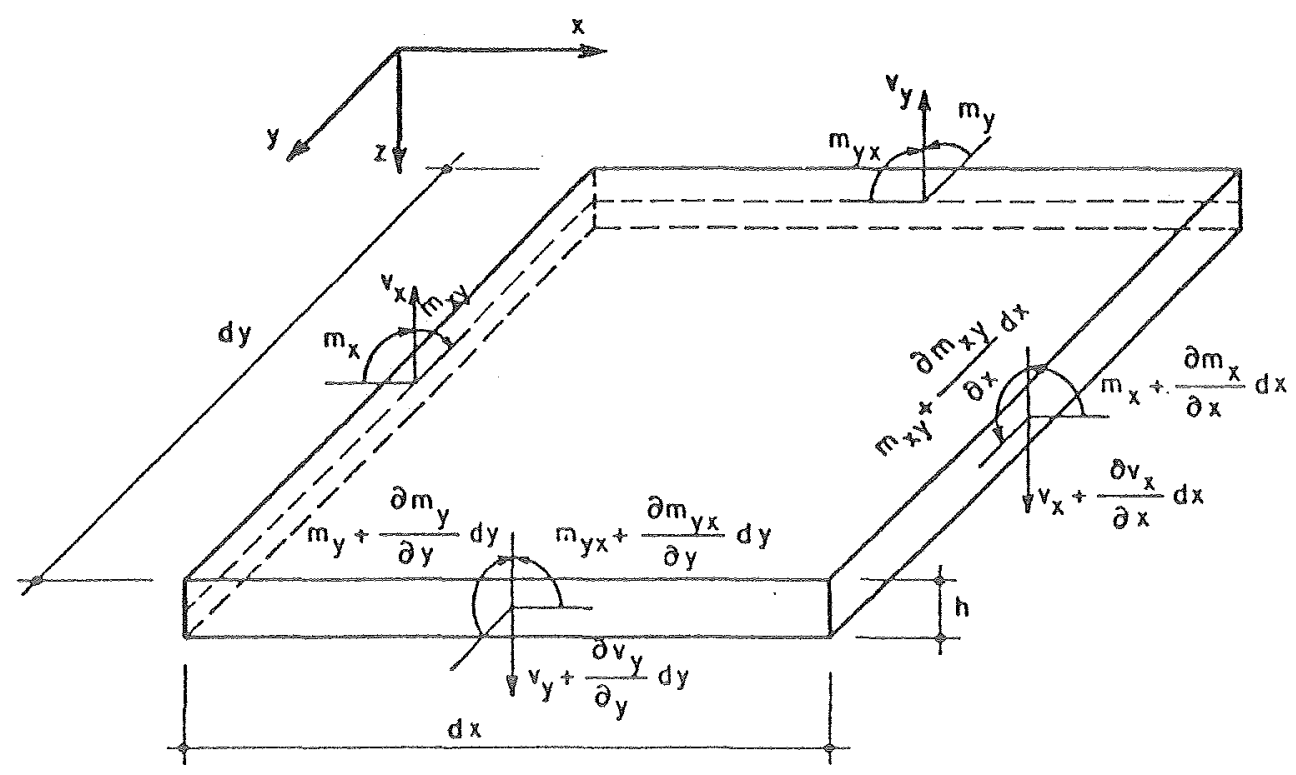

FIGURA 3.1- Esforços solicitantes em um elemento de placa

O desenvolvimento da formulação, encontrado em ampla bibliografia do assunto, como por exemplo em TIMOSHENKO [1940], não é explicitado aqui. No entanto, apresentam-se a seguir a equação diferencial das placas (equação de Lagrange) e as dos respectivos esforços solicitantes resultantes sobre as mesmas: 


$$
\begin{gathered}
\frac{\partial^{4} w}{\partial x^{4}}+2 \frac{\partial^{4} w}{\partial x^{2} \partial y^{2}}+\frac{\partial^{4} w}{\partial y^{4}}=\frac{p}{D} \\
m_{x}=-D \cdot\left[\frac{\partial^{2} w}{\partial x^{2}}+v \frac{\partial^{2} w}{\partial y^{2}}\right] \\
m_{y}=-D \cdot\left[\frac{\partial^{2} w}{\partial y^{2}}+v \frac{\partial^{2} w}{\partial x^{2}}\right] \\
m_{x y}=D \cdot(1-v) \cdot \frac{\partial^{2} w}{\partial x \partial y} \\
v_{y}=-D \cdot\left[\frac{\partial^{3} w}{\partial y^{3}}+\frac{\partial^{3} w}{\partial x^{2} \partial y}\right] \\
v_{x}=-D \cdot\left[\frac{\partial^{3} w}{\partial x^{3}}+\frac{\partial^{3} w}{\partial x \partial y^{2}}\right]
\end{gathered}
$$

com

$D=\frac{E h^{3}}{12\left(1-v^{2}\right)}=$ rigidez à flexão da placa, equivalente à rigidez El das vigas,

$E=$ módulo de deformação longitudinal,

$h=$ espessura,

$v=$ coeficiente de Poisson.

As condições de contorno da equação dif́erencial expressa acima dependem dos diferentes tipos de vinculação das bordas. Com isso, quando se trata, por exemplo, de uma borda reta paralela ao eixo $y$, ter-se-á, em função do comportamento admitido para essa borda, as seguintes condições de contorno possiveis: 
- borda engastada: o deslocamento vertical $(w)$ e a rotação $(\partial w / \partial x)$ são nulos;

- borda simplesmente apoiada: o deslocamento vertical $(w)$ e o momento fletor $\left(m_{x}\right)$ são nulos;

- borda livre: o momento fletor $\left(m_{x}\right)$ e a reação na borda $\left(v_{x}-\partial m_{x y} / \partial y\right)$ são nulos.

Com a obtenção da função $w$, os esforços solicitantes $m_{x}, m_{y}, v_{x}$ e $v_{y}$ são calculados pelas respectivas equações explicitadas anteriormente.

Ressalta-se, entretanto, que o processo de busca de uma função $w(x, y)$ que satisfaça à equação diferencial das placas e atenda às condições de contorno para uma laje submetida a um carregamento $p(x, y)$, torna-se um tanto quanto inviável devido às complicações algébricas a que conduz. Em função dessas dificuldades, recorre-se com frequiência a soluções aproximadas, obtendo-se $w(x, y)$ como uma soma de funções elementares (séries numéricas, como, por exemplo, as de Taylor) que satisfaçam às condições de contorno. No entanto, o processo de integração da equação de Lagrange mediante séries, apresenta o inconveniente de ser aplicável a alguns poucos casos de forma de placas e condições de apoio. Uma solução possível, favorecida pelo advento dos computadores, é o uso de integração numérica pelo processo das diferenças finitas, de aplicação mais geral e que conduz à resolução de um sistema de equaçỏes lineares. Este tipo de cálculo é preferencialmente aplicado para a elaboração de tabelas, através das quais obtêm-se facilmente os esforços em placas com formas e carregamentos mais comuns. Ao se tratar de placas com formas mais complexas, contendo aberturas, com regiões de diferentes espessuras, carregamentos não uniformes ou variadas condições de contorno, as tabelas anteriormente citadas não podem ser usadas. Deve-se, então, nestes casos, recorrer a outras alternativas mais refinadas de cálculo, como a técnica da analogia de grelha e o método dos elementos finitos, abordados mais adiante neste trabalho.

Citam-se também, como formas de cálculo mais refinadas, embora não abordadas aqui, o processo das faixas finitas e o método dos elementos de contorno. $O$ processo das faixas finitas se aplica principalmente às estruturas com apoios simples nos extremos, com a presença ou não de apoios intermediários, tendo ênfase para aplicação em tabuleiros de pontes. Mais informaçôes sobre este processo podem ser encontradas em CORRÊA [1983]. Com relação ao método dos elementos de contorno, constata-se que o mesmo constitui, ao lado do método dos elementos finitos, mais um tipo de aplicação de métodos numéricos em engenharia, como alternativa para solução analítica de problemas 
complexos. Seu procedimento consiste em discretizar o contorno de uma determinada região, dividindo-o em elementos e estabelecendo relações entre as incógnitas do problema em pontos do contorno. Busca a solução da equação diferencial que rege o domínio da região analisada através da solução de um sistema de equações integrais no contorno da mesma. Conhecendo-se as incógnitas no contorno, pode-se determinar, em função das mesmas, o comportamento em qualquer parte do domínio em estudo.

\subsubsection{Análise Linear com Redistribuição}

$A$ análise estrutural é definida como linear com redistribuição, conforme consta no TEXTO BASE PARA REVISÃO DA NB-1 [1994], quando os efeitos das ações, determinados em uma análise linear, são redistribuidos na estrutura, tendo em vista a fissuração da seção onde ocorre o momento fletor máximo. Trata-se da consideração de uma porcentagem de plastificação (limitada em $25 \%$, segundo indicações do referido texto base para revisão da NB-1) na referida seção. Nesses casos, as condições de equilíbrio e de ductilidade devem ser obrigatoriamente satisfeitas.

Os efeitos de redistribuição deverão ser considerados em todos os aspectos do projeto estrutural, inclusive as condições de ancoragem e corte de armaduras.

Todos os esforços internos deverão ser recalculados de modo a garantir o equilíbrio de cada um dos elementos estrulurais e da estrutura como um todo.

Cuidados especiais devem ser tomados com relação a carregamentos de grande variabilidade.

Quando for efetuada uma redistribuição, reduzindo-se um momento fletor de $\mathrm{M}$ para M, em uma determinada seção transversal, a relação entre o coeficiente e a posição da linha neutra nessa seção, visando a garantir condições de ductilidade, será dada por:

$$
\begin{array}{ll}
\delta \geq 0,44+1,25 \times / d \text { para concretos com } f_{\text {ck }} 35 \mathrm{MPa} & (\geq 0,75) \\
\delta \geq 0,56+1,25 x / d \text { para concretos com } f_{\text {ck }} 35 \mathrm{MPa} & (\geq 0,75)
\end{array}
$$





\subsection{ANÁLISE LIMITE OU PLÁSTICA}

$\mathrm{Na}$ análise plástica, admite-se que o concreto armado trabalha na iminência de ruptura, ou seja, que ele apresenta um comportamento correspondente a uma fase posterior à da análise não-linear de seu diagrama de tensão-deformação, caracterizada por escoamento de armaduras e pelo progresso de linhas de plastificação ao longo da sua estrutura. Admite-se, pois, neste tipo de análise, um comportamento rígido-plástico perfeito ou elasto-plástico perfeito para concreto armado, permitindo uma determinação adequada do valor da carga máxima que ele pode ser submetido numa solicitação, carga esta conhecida como carga de ruína ou carga última.

No caso particular das lajes, objeto deste trabalho, o cálculo exato pela teoria da plasticidade não é possivel, uma vez que o grau de indeterminação estática das mesmas é infinito. Com isso, em vez da obtenção do valor exato da carga última, determinam-se dois valores: um limite superior, dado pelo teorema cinemático, e um limite inferior, correspondente ao teorema estático. Estes dois teoremas, acompanhados pelo da unicidade, constituem a base fundamental para o desenvolvimento do cálculo plástico e são abordados de maneira sucinta a seguir.

\section{a) Teorema cinemático ou do limite superior}

Este teorema estabelece que toda carga correspondente a um mecanismo é de valor igual ou superior ao da carga de ruína da estrutura ou peça em análise. Dá-se o nome de mecanismo a toda e qualquer configuração de ruína cinematicamente admissivel. Este teorema permite, portanto, a definição de um limite superior para a carga efetiva de ruína, dando margens a um cálculo que pode ser contra a segurança, uma vez que dá margem para obienção de um valor superestimado da carga última.

A Teoria das Charneiras Plásticas (TCP) é uma aplicação deste teorema às lajes e constitui um instrumento de análise de esforços para a consideração do Estado Limite Último em placas, conforme indicações do TEXTO BASE PARA REVISÃO DA NB-1 [1994]. No capítulo 5, são apresentadas as hipóteses básicas e o desenvolvimento dos processos de cálculo para sua aplicaçăo, acompanhados de um exemplo prático sobre o pavimento de um edifício.

\section{b) Teorema estático ou do limite interior}

Estabelece que todo carregamento em equilíbrio com uma distribuição de esforços estaticamente admissivel apresenta valor igual ou inferior a que provoca a ruína. Entende- 
se por distribuição de esforços internos estaticamente admissível aquela que satisfaça às condições de contorno e que não ultrapasse a capacidade resistente da peça ou estrutura analisada. Permite, assim, a obtenção de um limite inferior para a carga de ruína e conduz a um cálculo a favor da segurança.

O processo das faixas de Hillerborg é um exemplo de aplicação deste teorema, baseando-se na determinação simplificada da distribuição de momentos, conforme se pode ver em HILLERBORG [1975].

A análise limite não pode ser adotada quando são considerados os efeitos de segunda ordem global ou quando não houver suficiente ductilidade para que as configurações previstas sejam atingidas.

Com o intuito de se garantir as condições adequadas de ductilidade, dispensando a verificação explícita da capacidade de rotação plástica da seção, prescrita no TEXTO BASE PARA REVISÃO DA NB1 [1994], deve-se ter a posição da linha neutra limitada em:

$$
x / d \geq 0,30 \text {. }
$$

A razão entre os momentos de extremidade ou de borda e momentos no vão ou centrais, na mesma direção, deve estar entre 0,5 e 2,0 .

\subsection{ANÁLISE NÄO-LINEAR}

A análise não-linear considera o concreto armado trabalhando com um comportamento não linear, levando em conta ou não os efeitos de segunda ordem, de acordo com o apresentado no TEXTO BASE PARA REVISÃO DA NB-1 [1994]. As condições de equilibrio, de compatibilidade e de ductilidade devem ser necessariamente satisfeitas. Este tipo de análise é permitida tanto para verificações de Estados Limites últimos como para verificações de Estados Limites de Utilização.

Elementos estruturais isolados ou mesmo estruturas compostas de vários elementos sob niveis de tensões tais que the conferem um comportamento em regime elástico não linear, podem ser analisados com o auxílio de métodos numéricos que admitem um diagrama momento-curvatura de cálculo e que em média, as seções planas permanecem planas.

Antes de sua realização é necessário fazer uma estimativa preliminar da disposição e quantidade de armaduras, uma vez que as mesmas influenciam seu desenvolvimento. 
Essa estimativa normalmente é feita através de modelos mais simples em análise linear. Todos os esforços internos, tensões, deslocamentos e deformações da estrutura devem ser calculados com base em valores médios das propriedades dos materiais $\left(E_{\mathrm{cm}}, f_{\mathrm{ctm}}, \mathrm{etc}\right.$ ), com exceção de regiões críticas (como por exemplo as de apoios, regiões de cargas concentradas, regiões de encontro de vigas) em que a resistência última precisa ser calculada, onde devem ser adotados valores de cálculo para essas propriedades.

Os valores finais das áreas de armaduras obtidos da análise não linear devem ser bem próximos daqueles previamente estimados. Havendo diferenças significativas, devem ser adotados os últimos resultados obtidos como estimativa preliminar e repetir-se 0 processo até sua convergência.

\subsection{ANÁLISE ATRAVÉS DE MODELOS FÍSICOS}

Neste tipo de análise, conforme apresentado no TEXTO BASE PARA REVISÃO DA NB-1 [1994], o comportamento do concreto armado é determinado a partir de ensaios realizados com modelos físicos em laboratório. É indicada quando os modelos de cálculo não são suficientes para uma boa previsão do comportamento real da estrutura.

Devem ser tomados cuidados especiais quanto à metodologia empregada nos experimentos a possibilidade de interpretação estatística dos resultados.

É necessária a simulação em ensaios de todos os Estados Limites últimos e de Utilização possíveis de serem empregados na análise da estrutura. Todas as ações, condiçôes e possíveis influências que possam ocorrer durante a vida da estrutura devem ser convenientemente reproduzidas em laboratório.

\subsection{CONSIDERAÇÕES FINAIS}

Neste capítulo foram apresentados sucintamente os fundamentos teóricos dos possiveis tipos de análise estrutural para os elementos de placa. A escolha de um ou outro tipo de análise depende do nível de solicitação que se esteja admitindo para o concreto armado. O presente trabalho aborda, entretanto, apenas os modelos de análise mais comumente empregados pelos projetistas, a saber, em análise linear (com ou sem redistribuição), através do cálculo com tabelas (desenvolvidas, em sua maioria, pela 
resolução da equação diferencial das placas por diferenças finitas), do cálculo através do método dos elementos finitos e da técnica da analogia de grelha e em análise limite ou plástica, através da teoria das charneiras plásticas. A não linearidade física das placas não é abordada aqui e melhores esclarecimentos sobre sua aplicação podem ser encontrados no Anexo 3 do TEXTO BASE PARA REVISÃO DA NB-1 [1994] e também no trabalho de CORREA [1991], onde se encontra expressivo estudo do assunto, com implementação computacional para a formulação utilizada e exemplo prático de cálculo do pavimento de um edifício. 


\section{MODELOS ESTRUTURAIS PARA ANÁLISE LINEAR DAS LAJES DE EDIFÍCIOS}

\subsection{INTRODUÇÃO}

A escolha de um modelo estrutural para a análise linear das lajes de um edifício depende, de modo mais genérico, do nível de dificuldades e particularidades que a forma do pavimento apresente. Formas estruturais mais simples podem ser calculadas através de modelos simplificados, ao passo que formas mais complexas requerem modelos mais refinados de análise. É importante ressaltar que mesmo para análise de formas simples é necessária muita atenção por parte do projetista, pois modelos que não contemplem a rigidez relativa entre elementos estruturais podem conduzir a resultados que além de serem imprecisos, sejam inseguros. Outro fator importante nesta escolha é maneira como são considerados os carregamentos atuantes sobre as lajes, principalmente quando da existência de ações concentradas devidas à presença de paredes atuando diretamente sobre as mesmas, pois modelos simplificados que as considerem como uniformemente distribuídas, conduzem a resultados também imprecisos.

O presente capitulo apresenta aspectos teóricos e práticos de alguns modelos de análise linear de lajes de edifícios, abrangendo desde os mais simples, com base no uso de tabelas que tratam as lajes isoladamente umas das outras, até os mais refinados como o método dos elementos finitos, que contempla de maneira mais precisa a interação entre os elementos estruturais que compõem o pavimento, como também a atuação dos carregamentos. É abordada ainda a análise através da técnica da analogia de grelha, que apesar de tratar as lajes como barras de uma grelha equivalente, constitui um bom modelo, possibilitando as mesmas considerações já citadas para o método dos elementos finitos.

Para cada um dos modelos citados, são apresentados os resultados de um exemplo de aplicação desenvolvido sobre o pavimento tipo do edifício Vitória Régia, projetado pelo Escritório Técnico José Roberto Leme de Andrade S/C Lida., São Carlos - SP, e construido na mesma cidade à Rua José Bonifácio, esquina com a Rua XV de Novembro, cuja planta 


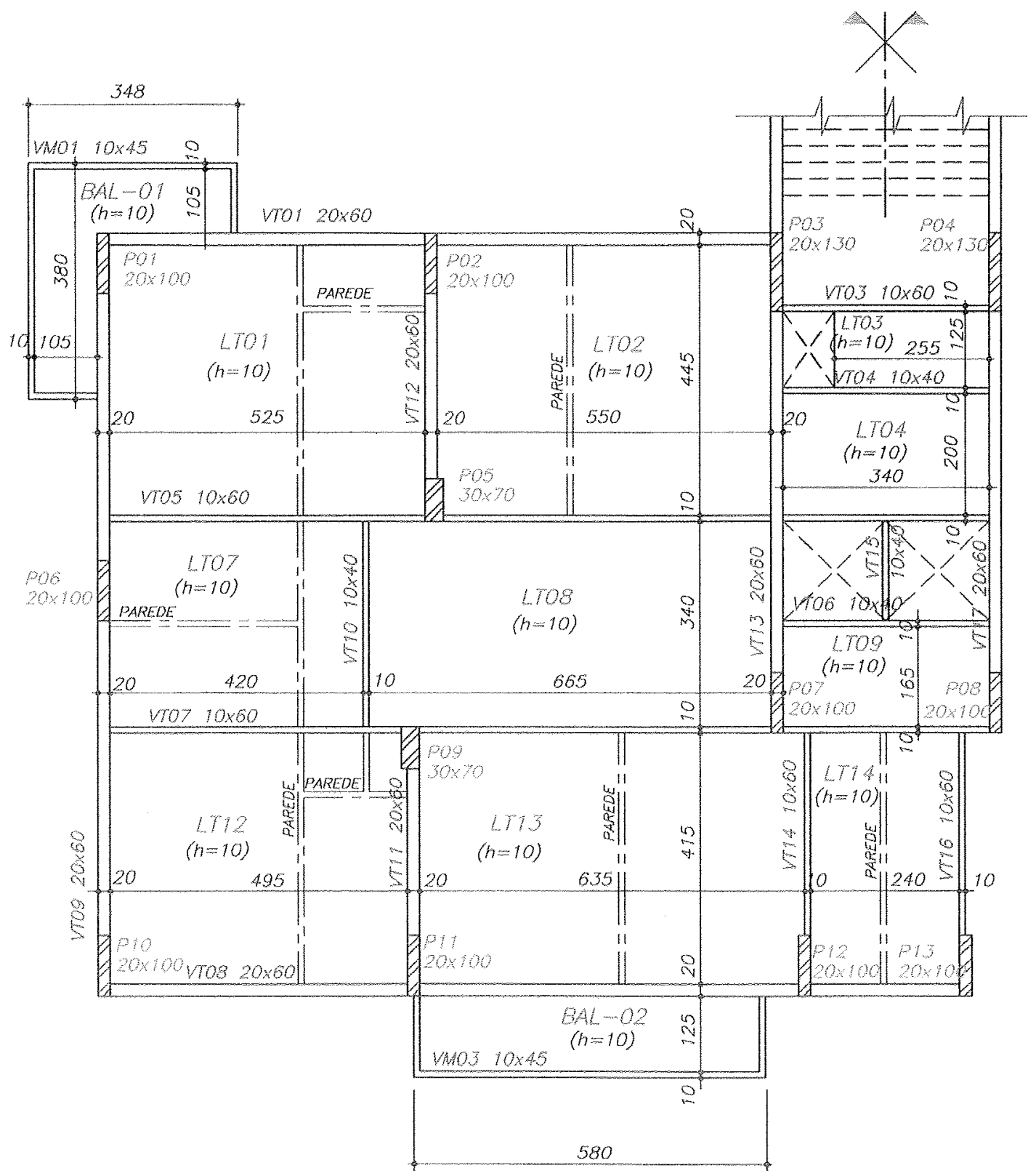

FIGURA 4.1 - Forma do pavimento tipo do Edifício Vitória Régia

de forma se apresenta FIGURA 4.1. Foram admitidos para o concreto armado o valor secante do módulo de deformaçăo longitudinal $E_{c}=2,754 \mathrm{E} 7 \mathrm{kN} / \mathrm{m}^{2}, 0,2$ para o coeficiente de Poisson e foram utilizados os seguintes valores de carregamentos:

Peso-próprio $=2,50 \mathrm{kN} / \mathrm{m}^{2}$ (espessura $=10 \mathrm{~cm}$ )

Piso + Revestimento $=1,00 \mathrm{kN} / \mathrm{m}^{2}$ 
Sobrecarga $=2,00 \mathrm{kN} / \mathrm{m}^{2}$

Ações devidas às alvenarias $(h=2,70 \mathrm{~m})$ situadas sobre as lajes: (já incluídas as ações da argamassa de assentamento e reboco ou azulejo)

Parede de 1 tijolo (furado ou baiano) $=3,13 \mathrm{kN} / \mathrm{m}^{2}$

Parede de 1 tijolo com azulejo $=3,43 \mathrm{kN} / \mathrm{m}^{2}$

Parede de $1 / 2$ tijolo $=1,99 \mathrm{kN} / \mathrm{m}^{2}$

Parede de $1 / 2$ tijolo $=2,30 \mathrm{kN} / \mathrm{m}^{2}$

A verificação das flechas nas lajes do pavimento estudado, é feita levando-se em consideração, para todos os modelos propostos, o efeito da deformação lenta, através da majoração da flecha inicial pela relação entre as curvaturas inicial e final da seção de maior momento fletor absoluto, conforme já mencionado neste trabalho. É admitido para o coeficiente $\beta_{c}$ (relação entre os encurtamentos máximos inicial e final do concreto) o valor 3 , ou seja, as ações de longa duração sendo colocadas logo após o descimbramento. Tomando por base a equação de compatibilidade de deformações, conforme esquematizado na FIGURA 4.2, e designando a relação entre a posição da linha neutra $(x)$ e a altura útil da seção (d) por um coeficiente $\beta_{x}$, resulta:

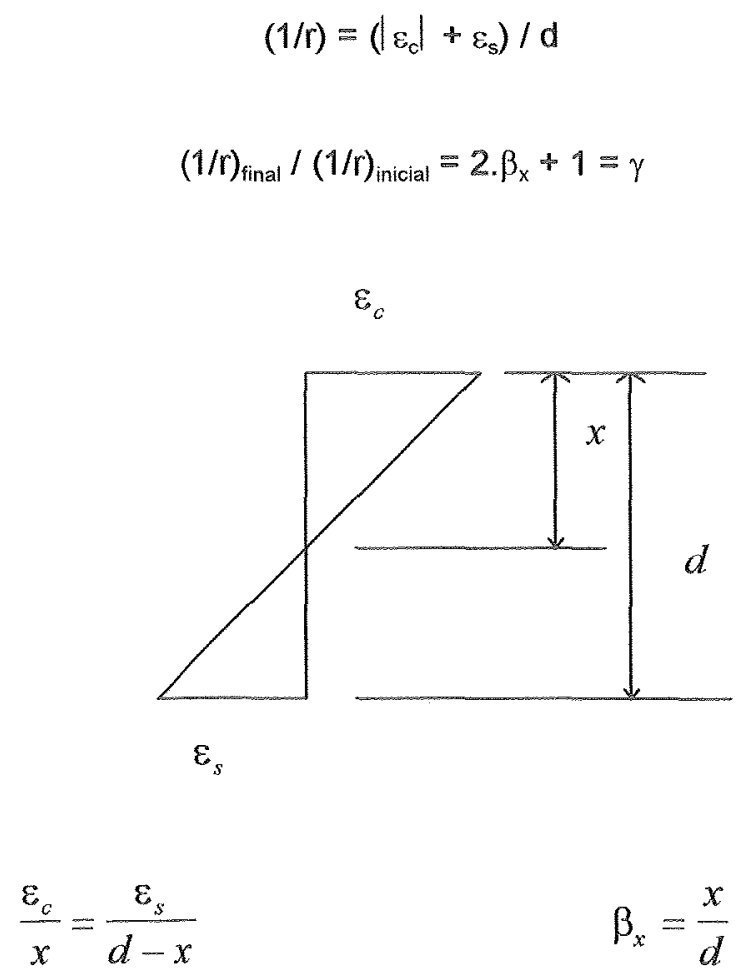

FIGURA 4.2 - Diagrama de deformação da seção de maior momento fletor - Equação de Compatibilidade 
A flecha final $\left(a_{f}\right)$ fica então determinada pela majoração da flecha inicial $\left(a_{i}\right)$ pelo coeficiente $\gamma$ :

$$
a_{f}=\gamma \cdot a_{i}
$$

Tendo em vista que a flecha inicial é diretamente proporcional ao carregamento considerado e visando a obtenção direta dos valores de flecha nos modelos com utilização de softwares, optou-se por majorar na mesma proporção a solicitação de cálculo prescrita pela NBR 8681 [1984] para a verificação do Estado Limite de Deformação Excessiva, a saber:

$$
s_{d}=s_{g k}+\chi s_{q k}
$$

sendo $\chi=0,2$ para o tipo de edificio adotado como exemplo.

Um valor razoável e a favor da segurança a considerar para o coeficiente $\beta_{x}$ é 0,7 , que é um valor próximo ao correspondente à transição dos domínios 3 e 4 de dimensionamento do concreto armado. Todas as seções a serem dimensionadas apresentarão, certamente, valores de $\beta_{\mathrm{x}}$ inferiores ao admitido acima. Deste modo, a solicitação de cálculo a considerar resulta na seguinte expressão:

$$
\begin{gathered}
S_{d}=\gamma \cdot S_{g k}+0,2 \cdot S_{q k} \\
S_{d}=\left(2 \cdot \beta_{x}+1\right) \cdot S_{g k}+0,2 \cdot S_{q k} \\
S_{d}=2,4 \cdot S_{g k}+0,2 \cdot S_{q k}
\end{gathered}
$$




\subsection{CÁLCULO APROXIMADO MEDIANTE O USO DE TABELAS - MÉTODO ELÁSTICO}

\subsubsection{Generalidades}

A aplicação do processo das diferenças finitas para integração da equação geral das placas elásticas é, conforme relatado anteriormente, de grande viabilidade para a elaboração de tabelas para cálculo aproximado dos esforços solicitantes nas placas de formas e carregamentos mais comumente encontrados.

Dentre estes processos de cálculo aproximado, encontra-se o de MARCUS [1929], de grande importância histórica, por ser o mais indicado da fase anterior aos computadores eletrônicos. É aplicável às lajes retangulares com carga uniforme e bordas apoiadas ou engastadas.

O grande impulso dado ao desenvolvimento dos métodos numéricos em engenharia com o advento dos computadores, possibilitou a elaboração de tabelas que substituem hoje, com muitas vantagens, as tabelas de Marcus encontradas, por exemplo, em ROCHA [1971]. Entre estas novas alternativas em tabelas, citam-se as de BARES [1972] e as de CZERNY [1976].

Ressalta-se que ao se lançar mão de um processo aproximado de cálculo, mediante o uso de tabelas, os painéis de laje são considerados independentemente das vigas que the servem de apoio, desprezando sua deformabilidade. As continuidades entre painéis são tratadas de formas simplificadas, como se não houvesse interação entre eles ou supondose engastamento fixo ou, ainda, buscando-se uma compatibilização dos momentos fletores adjacentes de um apoio, com posteriores correções dos momentos centrais. Todo o carregamento atuante na laje, incluindo as cargas de parede e sobrecargas de utilização, é admitido como uniforme sobre toda a superfície do painel. Tais considerações podem conduzir este tipo de análise a resultados muito imprecisos, dependendo da forma do pavimento que se queira analisar. Entretanto, são apresentados a seguir os resultados obtidos com o uso de tabelas para o pavimento tipo estudado, visando a comparação com os demais modelos propostos neste capítulo.

\subsubsection{Aplicação sobre o pavimento tipo do edificio Vitória Régia}

Apresentam-se, a seguir, através da TABELA 4.1, os resultados obtidos pela utilização de uma adaptação das tabelas de Bares, conforme encontrado em PINHEIRO [1986], sobre a forma do pavimento tipo do edifício vitória Régia. 
TABELA 4.1 - Momentos fletores e deslocamentos obtidos através do cálculo desenvolvido com auxílio de tabelas - método elástico

\begin{tabular}{|c|c|c|}
\hline \multicolumn{3}{|c|}{ MOMENTOS FLETORES E DESLOCAMENTOS AO LONGO DO CORTE A-A* } \\
\hline POSIÇÃO & $M_{x x}(k N . m / m)$ & DESLOCAMENTOS (cm) \\
\hline Borda LT12 & 0,00 & \\
\hline Centro LT12 & 3,19 & 0,52 \\
\hline Vinc. LT12/13 & $-8,60$ & \\
\hline Centro LT13 & 3,34 & 0,51 \\
\hline Vinc. LT13/14 & $-6,67$ & \\
\hline Centro LT14 & 2,39 & 0,09 \\
\hline Borda LT14 & $-6,67$ & \\
\hline \multicolumn{3}{|c|}{ * Corte A-A: Corte paralelo a VT07, passando pelo centro das lajes LT12/13/14 (FIG.4.1) } \\
\hline \multicolumn{3}{|c|}{ MOMENTOS FLETORES E DESLOCAMENTOS AO LONGO DO CORTE B-B* } \\
\hline POSIÇÃO & $\mathrm{M}_{\mathrm{yy}}(\mathrm{kN} \cdot \mathrm{m} / \mathrm{m})$ & DESLOCAMENTOS $(\mathrm{cm})$ \\
\hline Borda LT13 & 0,00 & \\
\hline Centro LT13 & 5,53 & 0,51 \\
\hline Vinc. LT13/08 & $-8,02$ & \\
\hline Centro LT08 & 2,49 & 0,14 \\
\hline Vinc. LT08/02 & $-9,89$ & \\
\hline Centro LT02 & 6,48 & 0,66 \\
\hline Borda LT02 & 0,00 & \\
\hline \multicolumn{3}{|c|}{ " Corte B-B: Corte paralelo a VT09, passando pelo centro das lajes LT13/08/02 (FIG.4.1) } \\
\hline \multicolumn{3}{|c|}{ MOMENTOS FLETORES E DESLOCAMENTOS NAS LAJES EM BALANÇO } \\
\hline POSIÇẤO & $\mathrm{M}(\mathrm{kN} . \mathrm{m} / \mathrm{m})$ & DESLOCAMENTOS $(\mathrm{cm})$ \\
\hline BAL-01 & $-6,92$ & 0,26 \\
\hline BAL_02 & $-8,85$ & 0,43 \\
\hline
\end{tabular}

\subsection{CÁLCULO ATRAVÉS DA TÉCNICA DA ANALOGIA DE GRELHA}

\subsubsection{Generalidades}

A técnica da analogia de grelha consiste na representação da laje ou mesmo do pavimento de um edifício através de uma grelha equivalente, de modo que as rigidezes longitudinais da laje sejam concentradas nas barras dessa direção e as rigidezes transversais nas barras da direção ortogonal a ela.

Foi usada pioneiramente em computador por LIGHTFOOT e SAWKO [1959], através da adaptação de um programa para cálculo de pórticos planos, tendo-se em vista a similaridade dos procedimentos de análise para pórticos planos e grelhas pelo método dos deslocamentos, bem como das equações básicas de compatibilidade de def́ormações. 
É bem indicada para ser utilizada no cálculo de tabuleiros de pontes como pode ser visto em HAMBLY [1976].

Têm-se referências também do uso da técnica para o cálculo de lajes cogumelo, com resultados satisfatórios, conforme relatam BRANCO [1989] e FIGUEIREDO [1989].

Mais recentemente, a técnica vem sendo utilizada como uma opção na análise das lajes usuais de edifícios, de acordo com o proposto por BARBOZA [1992] e cujo texto é tomado como base para o que é apresentado aqui.

"No processo de aplicação da técnica, deve-se garantir que as rigidezes das barras sejam tais que, ao submeterem-se as duas estruturas a um mesmo carregamento, elas se deformem de maneira idêntica e que os esforços solicitantes em qualquer barra da grelha sejam iguais às resultantes das tensões na seção transversal da parte da laje que a barra representa.

Para que um elemento infinitesimal de laje esteja em equilíbrio, de acordo com a teoria clássica de placas, é necessário que os momentos torçores em duas direções ortogonais sejam iguais. Na grelha equivalente obtida no desenvolvimento da técnica, não há princípios matemáticos ou físicos que garantam tal condição. Entretanto, se a malha da grelha for suficientemente pouco espaçada, a mesma se deformará formando uma superfície lisa e apresentará distorções aproximadamente iguais nas direçôes ortogonais, bem como momentos torçores aproximadamente iguais se as rigidezes à torção forem as mesmas na duas direçōes.

Convém ressaltar que nas barras da grelha os momentos fletores são proporcionais apenas às curvaturas de sua direção, fato este que resulta num inconveniente a mais no uso da técnica, uma vez que num elemento de placa, o momento fletor numa direção depende tanto da curvatura dessa direção como da ortogonal a ela." BARBOZA [1992]

Independentemente desses tipos de limitações da técnica, a mesma se apresenta como uma ferramenta a mais para a análise de lajes de edifícios, podendo ser considerada mais refinada que o cálculo clássico mediante tabelas, uma vez que leva em consideração a interação entre todos os elementos estruturais do pavimento e possibilita um posicionamento preciso das cargas concentradas devidas às ações das paredes situadas sobre as lajes.

\subsubsection{Critérios para traçado das malhas de grelha}

Diante da variabilidade de formas das lajes e dos diferentes tipos de carregamento, é difícil estabelecer-se ou definir-se uma malha como sendo genericamente a ideal para cada caso. Assim sendo, visando melhores esclarecimentos sobre o uso da técnica, apresentam-se a seguir, algumas consideraçỏes para sua correta aplicação neste trabalho. 
De acordo com indicações de HAMBLY [1976], apresentadas em BARBOZA [1992], são válidos os seguintes critérios para lajes retangulares, que devem ser adequados a cada tipo de laje que se deseja modelar:

a) As barras da grelha devem estar localizadas em posições pré-determinadas pelo projeto, tais como linhas de apoio ao longo das vigas de extremidade, bem como de outras se existirem, que contenham uma ação específica;

b) Em lajes ortótropas, cada barra deve ter no máximo uma largura igual a $1 / 4$ do vão transversal ao seu eixo;

c) Numa laje ortótropa, na direção de menor inércia, deve-se considerar a largura das barras igual a $40 \%$ do vão transversal ao seu eixo. Caso haja dúvidas quanto à isotropia ou ortotropia da laje, deve-se adotar o critério anterior;

d) Quanto mais densa a malha, melhores serão os resultados obtidos. No entanto, essa melhora deixa de acontecer quando a largura das barras for menor que duas ou três vezes a espessura da laje;

e) No caso de existência de balanços na laje, é necessário colocar-se pelo menos duas barras transversais ao vão em balanço;

f) Deve-se colocar uma linha de barras no contorno livre da laje, cuja largura para o cálculo do momento de inércia à torção deve ser diminuída de $0,3 \mathrm{~h}$, por se tratar do ponto por onde passa a resultante das tensões de cisalhamento devidas à torção;

g) Nas regiões de grande concentração de esforços, tais como apoios ou cargas concentradas, recomenda-se dispor uma malha cuja largura das barras não seja superior a três ou quatro vezes a espessura da laje;

h) Não devem ser considerados os orifícios na laje desde que sua maior dimensão não exceda $3 \mathrm{~h}$, sendo $\mathrm{h}$ a espessura da laje, a não ser que estejam localizados muito próximos dos pilares. Existindo aberturas maiores, devem ser aplicados os mesmos critérios válidos para as bordas livres.

O momento de inércia à flexão das barras longitudinais e transversais da grelha é calculado considerando que cada barra representa uma largura b de laje igual a distância 
entre os centros dos vãos adjacentes à barra, com valor dado pela respectiva equação estabelecida pela resistência dos materiais para as seções retangulares $\left(I=b . h^{3} / 12\right)$.. Para o momento de inércia à torção $\left(l_{T}\right)$ é admitido o valor correspondente àquele indicado pela teoria de Saint Venant, de acordo com a fórmula apresentada abaixo, encontrada em TIMOSHENKO [1981].

$$
I_{T}=\beta \cdot b \cdot c^{3}
$$

sendo b o maior lado da seção, $\mathrm{c}$ o menor lado e $\operatorname{com} \beta$ variando em função de uma relação entre os mesmos, de acordo com as indicações abaixo:

\begin{tabular}{l|lllllllllll}
$\mathrm{b} / \mathrm{c}$ & 1,00 & 1,50 & 1,75 & 2,00 & 2,50 & 3,00 & 4,00 & 6,00 & 8,00 & 10,00 & $\infty$ \\
\hline$\beta$ & 0,141 & 0,196 & 0,214 & 0,229 & 0,249 & 0,263 & 0,281 & 0,299 & 0,307 & 0,313 & 0,333
\end{tabular}

Outro aspecto importante que merece destaque na aplicação da técnica da analogia de grelha, é a consideração da vinculação dos pilares na grelha equivalente, de modo a avaliar a influência de suas rigidezes no comportamento do pavimento em análise. Esta influência é simulada aqui através da colocação de barras, nos tramos adjacentes ao nível analisado, com comprimentos de meio tramo, inércias correspondentes à do pilar que representam e com extremidades articuladas.

\subsubsection{Aplicação sobre o pavimento tipo do edificio Vitória Régia}

A aplicação da técnica sobre o pavimento tipo do Edifício Vitória Régia é feita âtravés do "software" SAP90, disponivel no Departamento de Estruturas da EESC - USP, São Carlos, e cujas instruções de uso encontram-se em WILSON \& HABIBULLAH [1988]. Foram processados dois modelos com elementos de barra, a saber, um com malha da ordem de $0,50 \mathrm{~m} \times 0,50 \mathrm{~m}$ e outro com malha da ordem de $1,00 \mathrm{~m} \times 1,00 \mathrm{~m}$, que não resultaram uniformes devido a ajustes na forma do pavimento analisado. Estas malhas, com as respectivas numeraçōes de nós consideradas, podem ser vistas nas FIGURAS 4.3 e 4.4. Ressalta-se que para as barras correspondentes às vigas do pavimento analisado, foram considerados valores reduzidos do momento de inércia à torção $(10 \%$ dos indicados anteriormente), tendo em vista a baixa resistência do concreto armado a este tipo de solicitação. Entretanto, para as barras da grelha equivalente, foram admitidos os valores indicados pela fórmula apresentada, visando a sua comparação com os resultados obtidos com o método dos elementos finitos, cujo modelo foi desenvolvido considerando-se a 
contribuição dos momentos volventes nos elementos de placa. Os resultados obtidos do processamento encontram-se nas TABELAS 4.2 e 4.3.

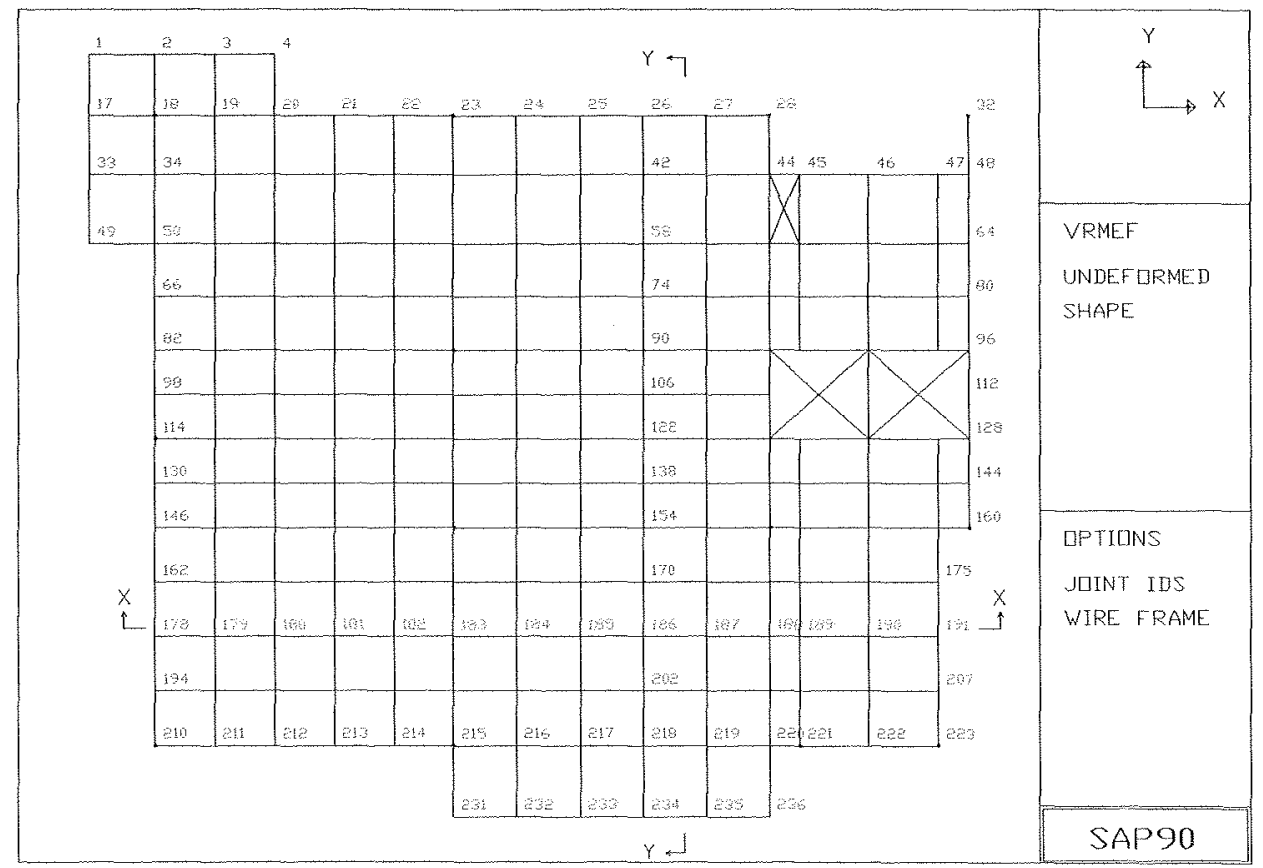

FIGURA 4.3 - Malha com espaçamento da ordem de 1,00 m x 1,00 m - Numeração dos nós

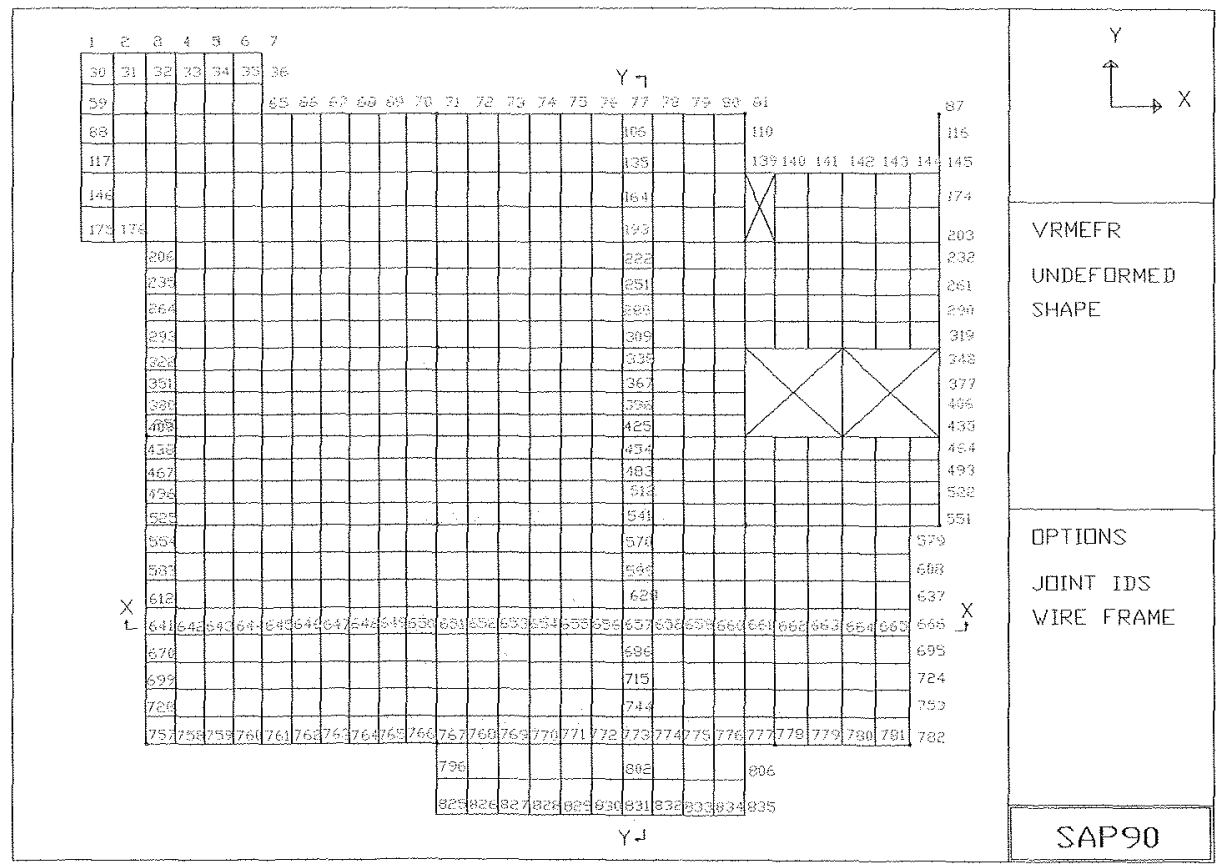

FIGURA 4.4 - Malha com espaçamento da ordem de 0,50 $\mathrm{m} \times 0,50 \mathrm{~m}$ - Numeração dos nós 
TABELA 4.2 - Momentos fletores e deslocamentos ao longo do Corte XX (ver figuras $4.3 \mathrm{e}$ 4.4) obtidos através da aplicação da técnica da analogia de grelha

\begin{tabular}{|c|c|c|c|c|c|}
\hline & \multicolumn{2}{|c|}{ MALHA 1,0 m } & & \multicolumn{2}{c|}{ MALHA 0,5 m } \\
\hline Nós & $\mathbf{M}_{\mathbf{x x}}(\mathbf{k N m} / \mathbf{m})$ & $\mathbf{D E S L}$ (cm) & Nós & $\mathbf{M}_{\mathbf{x x}}$ (kNm/m) & DESL. (cm) \\
\hline 178 & $-1,40$ & $-0,15$ & 641 & $-1,34$ & $-0,15$ \\
\hline & & & 642 & 1,72 & $-0,44$ \\
\hline 179 & 3,40 & $-0,72$ & 643 & 2,85 & $-0,69$ \\
\hline & & & 644 & 3,41 & $-0,88$ \\
\hline 180 & 4,14 & $-1,03$ & 645 & 3,79 & $-1,00$ \\
\hline & & & 646 & 4,29 & $-1,04$ \\
\hline 181 & 5,49 & $-0,99$ & 647 & 5,13 & $-0,97$ \\
\hline & & & 648 & 2,97 & $-0,78$ \\
\hline 182 & 0,82 & $-0,53$ & 649 & 0,47 & $-0,52$ \\
\hline & & & 650 & $-3,40$ & $-0,25$ \\
\hline 183 & $-9,76$ & $-0,06$ & 651 & $-10,00$ & $-0,06$ \\
\hline & & & 652 & $-4,05$ & $-0,07$ \\
\hline 184 & $-0,62$ & $-0,18$ & 653 & $-0,84$ & $-0,19$ \\
\hline & & & 654 & 0,85 & $-0,35$ \\
\hline 185 & 2,13 & $-0,49$ & 655 & 1,91 & $-0,49$ \\
\hline & & & 656 & 2,79 & $-0,59$ \\
\hline 186 & 4,10 & $-0,62$ & 657 & 3,88 & $-0,62$ \\
\hline & & & 658 & 2,25 & $-0,56$ \\
\hline 187 & 0,85 & $-0,42$ & 659 & 0,83 & $-0,43$ \\
\hline & & & 660 & $-0,64$ & $-0,29$ \\
\hline 188 & $-2,67$ & $-0,17$ & 661 & $-2,63$ & $-0,18$ \\
\hline 189 & $-6,21$ & $-0,15$ & 662 & $-6,35$ & $-0,16$ \\
\hline & & & 663 & 0,49 & $-0,26$ \\
\hline 190 & 6,12 & $-0,36$ & 664 & 5,19 & $-0,34$ \\
\hline & & & 665 & 3,15 & $-0,27$ \\
\hline 191 & $-0,14$ & $-0,11$ & 666 & $-0,13$ & $-0,11$ \\
\hline
\end{tabular}

Ao se analisar os resultados apresentados nas TABELAS 4.2 e 4.3, constata-se que a aplicação da técnica da analogia de grelha sobre a forma do pavimento estudado, conduziu a resultados convergentes ao se refinar o espaçamento das malhas de análise, tanto para os valores dos esforços momentos fletores como para os valores dos deslocamentos. As diferenças observadas nos valores de máximos positivos e negativos dos momentos fletores foram da ordem de 5 a $10 \%$, apresentando diferenças maiores que estas apenas em alguns pontos localizados. Para os deslocamentos, os valores apresentados foram praticamente idênticos. Ressalta-se que, com relação aos momentos 
fletores, os valores apresentados correspondem à média entre os fornecidos pelas barras consecutivas da direção considerada, uma vez que os mesmos eram diferentes em função da existência dos momentos de torção das barras da outra direção concorrentes no mesmo ponto. As FIGURAS 4.5 a 4.7 apresentam os resultados obtidos através de gráficos comparativos, ilustrando a tendência de convergência mencionada.

TABELA 4.3 - Momentos fletores e deslocamentos ao longo do Corte $Y$ (ver figuras $4.3 \mathrm{e}$ 4.4) obtidos através da aplicação da técnica da analogia de grelha

\begin{tabular}{|c|c|c|c|c|c|}
\hline & \multicolumn{2}{|c|}{ MALHA 1,0 m } & & \multicolumn{2}{c|}{ MALHA 0,5 m } \\
\hline Nós & $\mathbf{M}_{\mathrm{yy}}(\mathbf{k N m} / \mathbf{m})$ & DESL. (cm) & Nós & $\mathbf{M}_{\mathrm{yy}}(\mathrm{kNm} / \mathrm{m})$ & DESL. (cm) \\
\hline 234 & 0,01 & $-0,78$ & 831 & 0,01 & $-0,68$ \\
\hline & & & 802 & $-2,34$ & $-0,43$ \\
\hline 218 & $-7,72$ & $-0,29$ & 773 & $-7,78$ & $-0,29$ \\
\hline & & & 744 & $-1,93$ & $-0,35$ \\
\hline 202 & 1,65 & $-0,47$ & 715 & 1,32 & $-0,47$ \\
\hline & & & 686 & 3,13 & $-0,57$ \\
\hline 186 & 4,24 & $-0,62$ & 657 & 3,78 & $-0,62$ \\
\hline & & & 628 & 3,36 & $-0,58$ \\
\hline 170 & 2,27 & $-0,48$ & 599 & 1,74 & $-0,48$ \\
\hline & & & 570 & $-1,36$ & $-0,34$ \\
\hline 154 & $-6,75$ & $-0,24$ & 541 & $-7,20$ & $-0,23$ \\
\hline & & & 512 & $-3,39$ & $-0,24$ \\
\hline 138 & $-1,00$ & $-0,30$ & 483 & $-0,77$ & $-0,29$ \\
\hline & & & 454 & 0,81 & $-0,37$ \\
\hline 122 & 1,83 & $-0,45$ & 425 & 1,56 & $-0,44$ \\
\hline & & & 396 & 1,53 & $-0,49$ \\
\hline 106 & 0,83 & $-0,54$ & 367 & 0,64 & $-0,53$ \\
\hline & & & 338 & $-1,21$ & $-0,56$ \\
\hline 90 & $-3,76$ & $-0,62$ & 309 & $-4,01$ & $-0,61$ \\
\hline & & & 280 & $-0,16$ & $-0,71$ \\
\hline 74 & 2,30 & $-0,83$ & 251 & 1,92 & $-0,82$ \\
\hline & & & 222 & 2,88 & $-0,88$ \\
\hline 58 & 3,47 & $-0,89$ & 193 & 3,15 & $-0,89$ \\
\hline & & & 164 & 3,09 & $-0,80$ \\
\hline 42 & 3,08 & $-0,62$ & 135 & 2,66 & $-0,62$ \\
\hline & & & 106 & 1,75 & $-0,39$ \\
\hline 26 & $-1,28$ & $-0,13$ & 77 & $-1,26$ & $-0,13$ \\
\hline
\end{tabular}




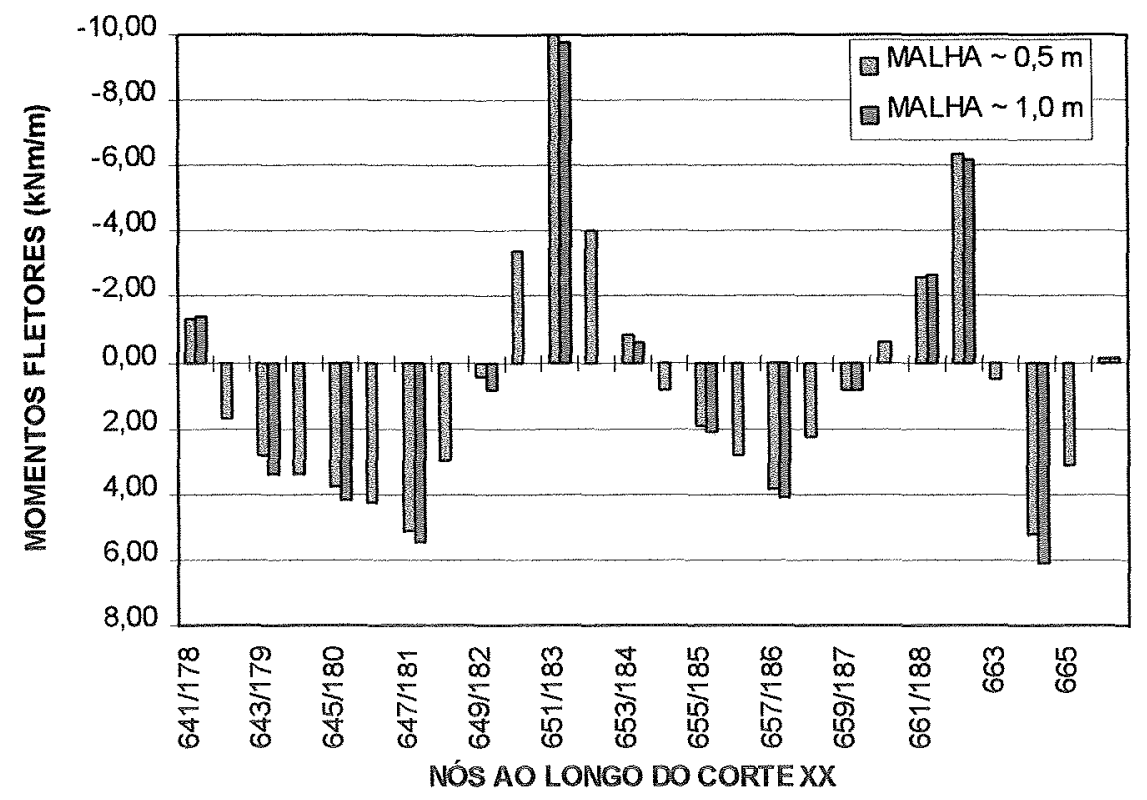

FIGURA 4.5 - Momentos fletores ao longo do Corte XX (ver Figuras 4.3 e 4.4), obtidos através da aplicação da técnica da analogia de grelha

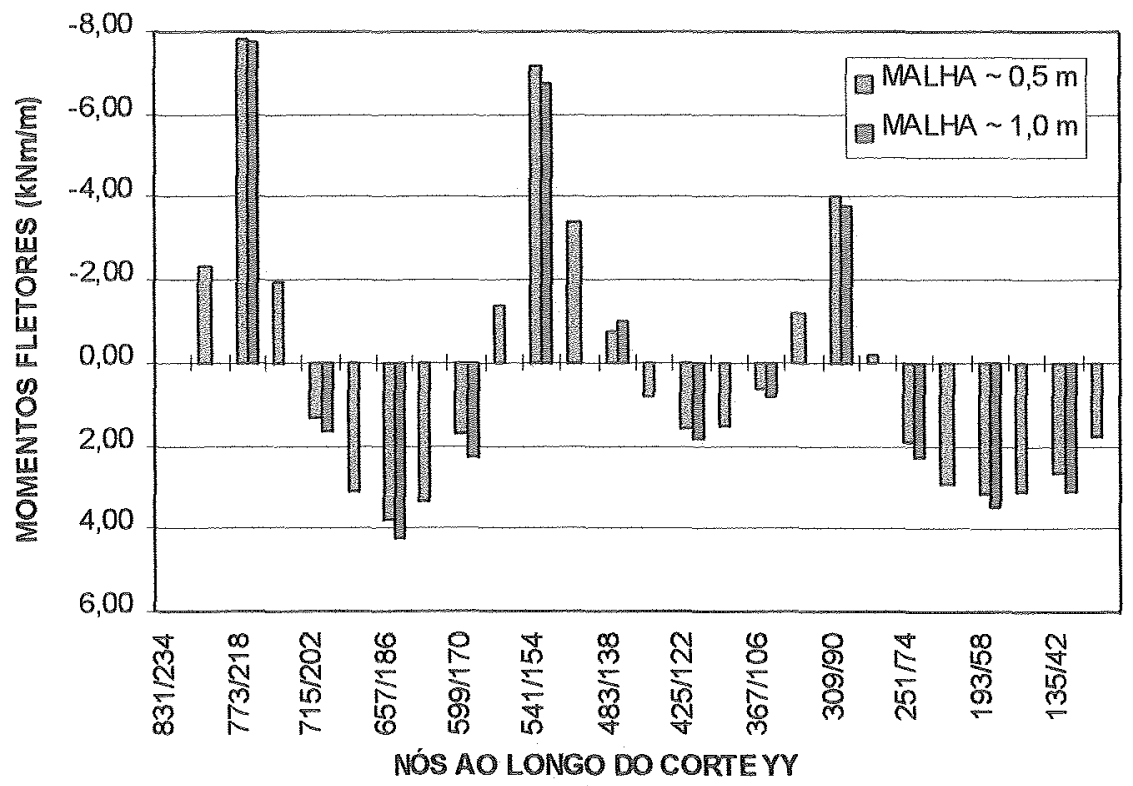

FIGURA 4.6 - Momentos fletores ao longo do Corte YY (ver Figuras 4.3 e 4.4), obtidos através da aplicação da técnica da analogia de grelha 


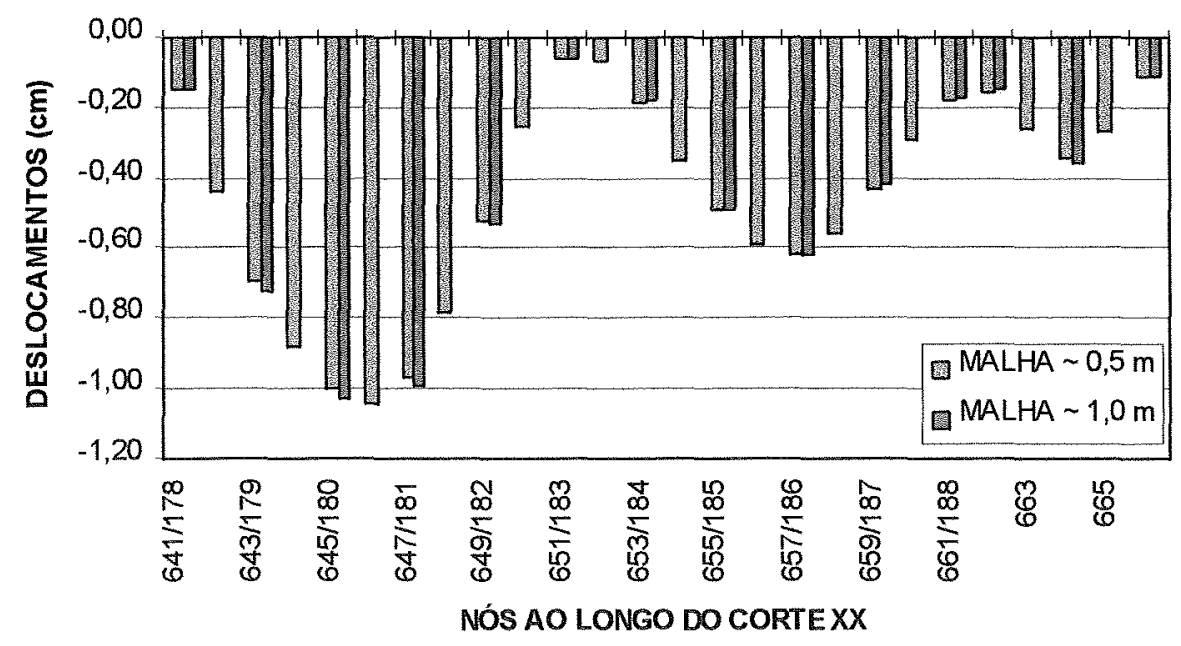

FIGURA 4.7 - Deslocamentos ao longo do Corte XX (ver Figuras 4.3 e 4.4), obtidos através da aplicação da técnica da analogia de grelha

\subsection{ANÁLISE ATRAVÉS DO MÉTODO DOS ELEMENTOS FINITOS}

\subsubsection{Generalidades}

O método dos elementos finitos constitui atualmente uma das mais refinadas ferramentas de análise estrutural no que diz respeito à aplicação de métodos numéricos em engenharia. Os primeiros sinais do aparecimento de sua teoria datam do início da década de 60, como uma tentativa de utilização da máquina, tendo-se em vista o advento dos computadores, para tratamento de problemas de um meio contínuo via discretização do mesmo.

Os elementos finitos retangulares apresentam-se como pioneiros no processo de desenvolvimento do método para a análise de placas fletidas. Um dos primeiros é o de MELOSH [1961], cuja formulação baseia-se numa analogia entre a placa e um sistema de barras cruzadas, técnica conhecida como analogia de grelha e já abordada no trabalho. Um importante elemento finito usando uma função de interpolação cúbica acrescida de dois termos de quarta ordem ( do tipo $x^{3} y$ e $x y^{3}$ ) para o campo de deslocamentos é o elemento ACM, abordado em ZIENKIEWICZ \& CHEUNG [1964], MELOSH [1963] e ARGYRIS [1965]. Vários elementos retangulares utilizando tensões (modelo híbrido) no funcional vêm sendo apresentados por PIAN \& TONG [1968], SEVERN e TAYLOR [1966] e NEALE et al [1972]. 
Elementos quadrilaterais com formulação desenvolvida mediante o modelo híbrido são apresentados por ALLWOOD e CORNES [1969], e TORBE e CHURCH [1975]. HORRIGMOE [1978] usa um elemento com uma distribuição linear de momentos fletores em seu interior. Uma grande variedade de elementos com doze graus de liberdade em modelo híbrido é apresentada e discutida por COOK [1972,1974,1976].

"As primeiras tentativas de desenvolvimento de elementos triangulares remontam à década de 1960. No trabalho de CLOUGH e TOCHER [1965] são relatadas algumas experiências com elementos triangulares com nove graus de liberdade. As devidas a Adini (1961) e Tocher (1962) utilizam polinômios cúbicos nas coordenadas x e y para a descrição do campo de deslocamentos, com redução de dez a nove termos, para haver igualdade com número de graus de liberdade. Analisando os defeitos na utilização desses polinômios, os autores propõem a subdivisão do elemento em três subdomínios triangulares, na construção de um elemento compatível, com nove graus de liberdade, o HCT, um dos mais utilizados ao longo de toda a história do método dos elementos finitos. Esse elemento é reapresentado por CLOUGH e FELIPPA [1968] com o nome de LCCT9 junto com outros triangulares LCCT10, LCCT11 e LCCT12, para a montagem de elementos quadrilaterais." CORREA [1991]

O desenvolvimento de elementos quadrilaterais, näo necessariamente retangulares, pode ser feito através de uma associação de elementos triangulares, sendo que se forem consideradas mais de duas subregiões, deve ser usada uma condensação estática para a definição de um elemento de doze graus de liberdade. Os elementos Q15 apresentado em BATHE et al [1974] e Q19 em CLOUGH \& FELIPPA [1968] são exemplos desse tipo de elemento.

Com a adoção da Teoria de Reissner-Mindlin para placas espessas, através de uma generalização das hipóteses de Kirchhoff ("pontos da placa originalmente situados sobre uma reta normal à superfície média indeformada, permanecem sobre uma linha reta, mas não necessariamente normal à superfície média deformada"), novos elementos são propostos utilizando-se o modelo em deslocamentos. "A vantagem dessa teoria está no fato de que as derivadas primeiras são as de mais alta ordem que aparecem no funcional, exigindo continuidade $\mathrm{C}^{0}$ nas fronteiras do elemento para obtenção de conformidade. MELOSH [1965] apresenta os primeiros elementos triangulares do tipo $\mathrm{C}^{0}$, aplicados à análise de placas, com inúmeros problemas, entretanto, para placas finas e elementos de ângulos obiusos. O sucesso com elementos desse tipo acontece somente na década de 70 , primeiramente com elementos quadrilaterais como em ZIENKIEWICZ et al [1971], HUGHES et al [1977] e, PUGH et al [1978], acompanhados por triangulares como os desenvolvidos por ARGYRIS et al [1977] e BELYTSCHKO et al [1984]". CORREA [1991] 
Um outro elemento triangular que merece atenção é o DKT (Discrete Kirchhoff Theory), cuja formulação é desenvolvida com base num modelo em deslocamentos com a imposição das hipóteses de Kirchhoff de um modo discreto, ao longo dos lados do elemento ou em determinados pontos do mesmo, como por exemplo, os pontos de integração de Gauss. O bom comportamento de um elemento DKT é apresentado em BATOZ et al [1980], [1982], e também no trabalho de ZIENKIEWICZ [1990] onde são feitos vários estudos sobre esse tipo de elemento.

Aqui neste trabalho não é apresentada a formulação de nenhum elemento, uma vez que não se tem o intuito de desenvolver uma implementação computacional para este modelo. A utilização do método é feita através do "software" SAP90 que não explicita, no manual de instruções, o tipo de elemento finito de placa admitido pelo mesmo.

\subsubsection{Características do método e modelos de elementos finitos}

As duas características principais do método são a subdivisão da estrutura em partes finitas (elementos), interligando-as entre si através de um número discreto de pontos em sua periferia (nós) e a escolha da função que descreve o comportamento interno dessas pequenas partes ou elementos. Esta última constitui a mais fundamental das características, uma vez que o bom ou mau comportamento do elemento é que vai viabilizar ou não o uso do método.

O comportamento do elemento é então descrito por uma função ou um conjunto de funçőes especialmente escolhidas, que permitem analisar como se comportam as tensões e os deslocamentos dentro daquele elemento, quando o mesmo é submetido a determinado tipo de ação. São estas funções que vão indicar a maneira específica de se deformar de cada elemento.

Em função do tipo de comportamento assumido sobre cada elemento e do princípio variacional utilizado, existem várias alternativas para a formulação de elementos. Essas formulações são normalmente chamadas modelos de elementos finitos. Resumidamente, de acordo com o apresentado em QUIRINO [1986], alguns dos modelos possíveis são:

a) Modelo em Deslocamentos: - usa o princípio da mínima energia potencial. Supõe campos de deslocamentos contínuos sobre cada elemento. As incógnitas são os deslocamentos nodais.

b) Modelo Flexível: - usa o princípio da mínima energia complementar. Assume campos de tensőes em equilíbrio. As incógnitas básicas são as tensões nos pontos nodais, embora, eventualmente, elas possam ser trocadas pelos deslocamentos nodais. 
c) Modelo Hibrido: - Existem dois tipos básicos:

Tipo I - baseado no princípio da mínima energia complementar modificado. Supõe campos de equilíbrio de tensões sobre cada elemento e campos de deslocamentos compativeis sobre os contornos dos elementos. As incógnitas são os deslocamentos nodais.

Tipo II - usa o princípio da mínima energia potencial modificado. campos de deslocamentos contínuos são supostos sobre cada elemento, enquanto o equilíbrio de forças é considerado sobre os contornos dos elementos. As equações governantes são estabelecidas em termos das forças de contorno.

d) Modelo Misto: - supõe campos de deslocamentos contínuos e campos de equilíbrio de tensões sobre cada elemento. As equações governantes apresentam-se em termos de deslocamentos nodais e tensões ou forças como incógnitas.

Dentre os modelos acima citados, o modelo em deslocamentos é um dos mais difundidos no âmbito da engenharia de estruturas.

\subsubsection{Compatibilidade de elementos a critérios de convergência}

No processo de aplicação do método dos elementos finitios, são importantes os conceitos de compatibilidade ou conformidade de elementos, bem como os de critérios de convergência para a análise da solução.

A compatibilidade pode ser verificada tanto no interior do elemento como em seus limites, na fronteira com os elementos vizinhos. No interior do elemento, a compatibilidade pode ser satisfeita automaticamente ao admitir-se funções polinomiais para caracterizar o campo de deslocamentos nesse elemento. Já na região limite entre elementos, para que os mesmos sejam considerados compatíveis ou conformes, é necessário que a função adotada para representar os deslocamentos ao longo dos lados do elemento e no seu interior seja contínua e diferenciável.

Com relação à convergência na solução de um problema particular, para se assegurar que a seqüência de resultados se aproxima teoricamente do resultado exato quando se refina a malha de elementos, alguns critérios gerais devem ser observados, conforme visto em COOK [1989] e exposto a seguir para o modelo em deslocamentos.

Admite-se que a variável campo seja uma função $\phi=\phi(x, y, z)$ e que exista um funcional $\pi=\pi(\phi)$ que gere a equação diferencial determinante do problema físico de 
condição estacionária $\mathrm{d} \pi=0$. Assume-se ainda que $\pi$ contém derivadas de $\phi$ de ordem $\mathrm{m}$. Se o valor exato de $\phi$ é aproximado quando a malha é refinada, então:

1) Dentro de cada elemento, a função $\phi$ escolhida para representar o campo de deslocamentos deve ser um polinômio completo de grau m;

2) Deve haver continuidade de $\phi$ e de suas derivadas de ordem ( $m-1)$, através dos limites entre elementos;

3) Analisando-se os elementos em uma malha e admitindo que as condições limites sobre a mesma sejam apropriadas para a obtenção de um valor constante de alguma das m-ésima derivadas de $\phi$, então, quando a malha é refinada, cada elemento deve apresentar para essa derivada o referido valor constante.

Por exemplo, se $\phi=\phi(x, y)$ e $\pi$ contém as derivadas primeiras de $\phi$, então a mais baixa ordem aceitável para a função campo de deslocamentos, em cada elemento, tem a forma $\phi=a_{1}+a_{2} x+a_{3} y$ e somente $\phi$ própria necessita ser contínua através dos limites interelementos. Cada elemento de uma malha carregada apropriadamente deve apresentar um valor constante da derivada de $\phi$ com relação a $x$, pelo menos quando a malha é refinada.

A satisfação dos critérios 1, 2 e 3 anteriores garante a convergência para resultados corretos, mas nada diz sobre a precisão numa malha grossa ou sobre a razão de convergência com o refinamento da malha. Entretanto, se os critérios são atendidos em todos os estágios de refinamento da malha, e se cada refinamento é obtido pela divisão dos elementos da malha anterior em dois ou mais elementos, então a convergência é monotônica.

Uma maneira de se assegurar que um determinado tipo de elemento atende a todos os critérios de convergência citados é verificar se ele atende ao teste conhecido como "Patch Test". Este foi proposto por IRONS [1966] e constitui-se de um simples teste que pode ser realizado numericamente, como uma forma de checar a validade da formulação de um elemento. O procedimento de execução do teste consiste em analisar o comportamento de um pequeno grupo de elementos durante um estado de deformação constante, verificando se ocorre produção ou perda de energia em cada elemento isoladamente, bem como em seus contornos. Pode ser realizado, por exemplo, impondo-se a um grupo de elementos deslocamentos nodais compativeis com um estado de deformação constante. Se a deformação de tais elementos está de acordo com o estado aplicado e de tal modo que as forças nodais induzidas nos nós internos se anulam, devido à contribuição de todos os elementos a ele conectados, então o teste está atendido. 


\subsubsection{Aplicação sobre o pavimento tipo do edifício Vitória Régia}

A análise do pavimento tipo do Edifício Vitória Régia através do método dos elementos finitos é feita através do "software" SAP90. Foram processados dois modelos com elementos de placa, a saber, um com malha da ordem de $0,50 \mathrm{~m} \times 0,50 \mathrm{~m}$ e outro com malha da ordem de 1,00 $\mathrm{m} \times 1,00 \mathrm{~m}$. Estas malhas, com as respectivas numerações de nós consideradas, podem ser vistas nas FIGURAS 4.3 e 4.4. As propriedades dos materiais, bem os carregamentos considerados foram os mesmos apresentados na introdução deste capítulo, ressaltando-se que para o momento de inércia à torção das vigas do pavimento e para a simulação da influência dos pilares sobre o mesmo, foram admitidas as mesmas considerações já mencionadas na aplicação da técnica da analogia de grelha (item 4.3.3). Os resultados obtidos do processamento encontram-se nas TABELAS 4.4 e 4.5 .

TABELA 4.4 - Momentos Fletores e deslocamentos ao longo do Corte XX (ver Figuras $4.3 \mathrm{e}$ 4.4), obtidos através da análise com o método dos elementos finitios

\begin{tabular}{|c|c|c|c|c|c|}
\hline & \multicolumn{2}{|c|}{ MALHA $\sim 1,0 \mathrm{~m}$} & & \multicolumn{2}{|c|}{ MALHA $\sim 0,5 \mathrm{~m}$} \\
\hline Nós & $M_{x x}(k N m / m)$ & DESL. (cm) & Nós & $\mathrm{M}_{\mathrm{xx}}(\mathrm{kNm} / \mathrm{m})$ & DESL: $(\mathrm{cm})$ \\
\hline \multirow[t]{2}{*}{178} & $-1,33$ & $-0,15$ & 641 & $-1,29$ & $-0,15$ \\
\hline & & & 642 & 1,70 & $-0,41$ \\
\hline \multirow[t]{2}{*}{179} & 3,61 & $-0,64$ & 643 & 3,39 & $-0,66$ \\
\hline & & & 644 & 4,32 & $-0,85$ \\
\hline \multirow[t]{2}{*}{180} & 5,17 & $-0,92$ & 645 & 4,92 & $-0,96$ \\
\hline & & & 646 & 5,50 & $-0,99$ \\
\hline \multirow[t]{2}{*}{181} & 5,39 & $-0,87$ & 647 & 5,68 & $-0,92$ \\
\hline & & & 648 & 3,81 & $-0,74$ \\
\hline \multirow[t]{2}{*}{182} & 1,44 & $-0,46$ & 649 & 0,92 & $-0,49$ \\
\hline & & & 650 & $-3,32$ & $-0,23$ \\
\hline \multirow[t]{2}{*}{183} & $-9,20$ & $-0,06$ & 651 & $-9,78$ & $-0,06$ \\
\hline & & & 652 & $-3,77$ & $-0,07$ \\
\hline \multirow[t]{2}{*}{184} & 0,22 & $-0,20$ & 653 & $-0,45$ & $-0,19$ \\
\hline & & & 654 & 1,45 & $-0,35$ \\
\hline \multirow[t]{2}{*}{185} & 3,02 & $-0,49$ & 655 & 2,68 & $-0,49$ \\
\hline & & & 656 & 3,67 & $-0,58$ \\
\hline \multirow[t]{2}{*}{186} & 3,94 & $-0,58$ & 657 & 4,24 & $-0,61$ \\
\hline & & & 658 & 3,11 & $-0,55$ \\
\hline \multirow[t]{2}{*}{187} & 1,85 & $-0,43$ & 659 & 1,62 & $-0,43$ \\
\hline & & & 660 & 0,05 & $-0,29$ \\
\hline 188 & $-1,26$ & $-0,19$ & 661 & $-2,14$ & $-0,18$ \\
\hline \multirow[t]{2}{*}{189} & $-5,42$ & $-0,14$ & 662 & $-5,93$ & $-0,15$ \\
\hline & & & 663 & 0,91 & $-0,23$ \\
\hline \multirow[t]{2}{*}{190} & 4,58 & $-0,25$ & 664 & 4,61 & $-0,29$ \\
\hline & & & 665 & 3,30 & $-0,25$ \\
\hline 191 & $-0,17$ & $-0,11$ & 666 & $-0,13$ & $-0,11$ \\
\hline
\end{tabular}


TABELA 4.5 - Momentos Fletores e deslocamentos ao longo do Corte $Y Y$ (ver Figuras $4.3 \mathrm{e}$ 4.4), obtidos através da análise com o método dos elementos finitos

\begin{tabular}{|c|c|c|c|c|c|}
\hline & \multicolumn{2}{|c|}{ MALHA 1,0 m } & \multicolumn{3}{c|}{ MALHA 0,5 m } \\
\hline Nós & $\mathbf{M}_{\mathrm{yy}}(\mathbf{k N m} / \mathbf{m})$ & DESL. (cm) & Nós & $\mathbf{M}_{\mathbf{y y}}$ (kNm/m) & DESL. (cm) \\
\hline 234 & $-0,03$ & $-0,77$ & 831 & 0,00 & $-0,68$ \\
\hline & & & 802 & $-1,98$ & $-0,44$ \\
\hline 218 & $-7,68$ & $-0,29$ & 773 & $-7,64$ & $-0,29$ \\
\hline & & & 744 & $-1,83$ & $-0,35$ \\
\hline 202 & 2,06 & $-0,44$ & 715 & 1,81 & $-0,46$ \\
\hline & & & 686 & 3,90 & $-0,56$ \\
\hline 186 & 4,90 & $-0,58$ & 657 & 4,66 & $-0,61$ \\
\hline & & & 628 & 4,14 & $-0,57$ \\
\hline 170 & 2,58 & $-0,45$ & 599 & 2,26 & $-0,47$ \\
\hline & & & 570 & $-1,16$ & $-0,33$ \\
\hline 154 & $-6,38$ & $-0,23$ & 541 & $-6,88$ & $-0,23$ \\
\hline & & & 512 & $-3,05$ & $-0,24$ \\
\hline 138 & 0,16 & $-0,31$ & 483 & $-0,53$ & $-0,29$ \\
\hline & & & 454 & 1,08 & $-0,37$ \\
\hline 122 & 2,32 & $-0,45$ & 425 & 1,87 & $-0,44$ \\
\hline & & & 396 & 1,84 & $-0,49$ \\
\hline 106 & 1,33 & $-0,54$ & 367 & 0,95 & $-0,53$ \\
\hline & & & 338 & $-0,92$ & $-0,56$ \\
\hline 90 & $-3,64$ & $-0,61$ & 309 & $-3,90$ & $-0,61$ \\
\hline & & & 280 & 0,06 & $-0,72$ \\
\hline 74 & 2,81 & $-0,82$ & 251 & 2,54 & $-0,83$ \\
\hline & & & 222 & 3,86 & $-0,91$ \\
\hline 58 & 4,68 & $-0,91$ & 193 & 4,40 & $-0,93$ \\
\hline & & & 164 & 4,40 & $-0,85$ \\
\hline 42 & 3,87 & $-0,63$ & 135 & 3,61 & $-0,65$ \\
\hline & & & 106 & 1,89 & $-0,40$ \\
\hline 26 & $-1,54$ & $-0,13$ & 77 & $-1,30$ & $-0,13$ \\
\hline & & & & & \\
\hline
\end{tabular}

Ao observarem-se os valores expostos nas tabelas acima, pode-se notar que houve convergência nos resultados apresentados pelas duas malhas analisadas através do método dos elementos finitos, tanto para os esforços momentos fletores, como para as deslocamentos. As diferenças máximas obsenvadas para os valores de momentos fletores máximos positivos e negativos foram da ordem de 5 a $10 \%$ e para os deslocamentos da ordem de $5 \%$. As FIGURAS 4.8 a 4.11 apresentam os resultados da análise em gráficos comparativos, mostrando mais claramente a tendência de convergência mencionada. 


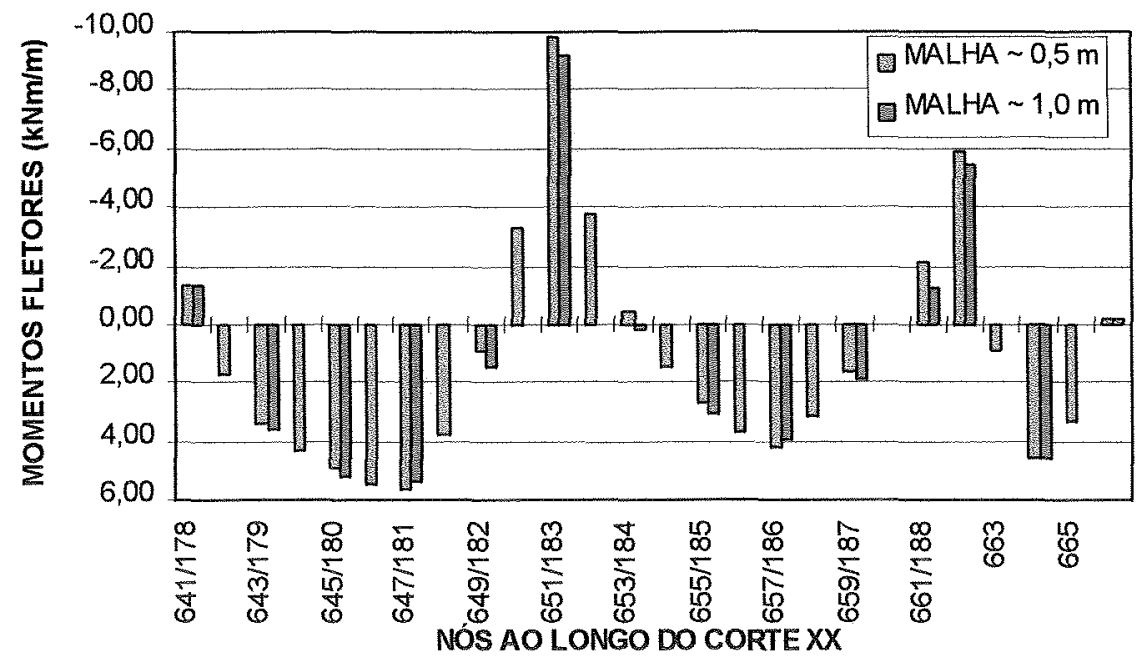

FIGURA 4.8 - Momentos fletores ao longo do Corte XX (ver Figuras 4.3 e 4.4 ), obtidos através da análise com o método dos elementos finitos

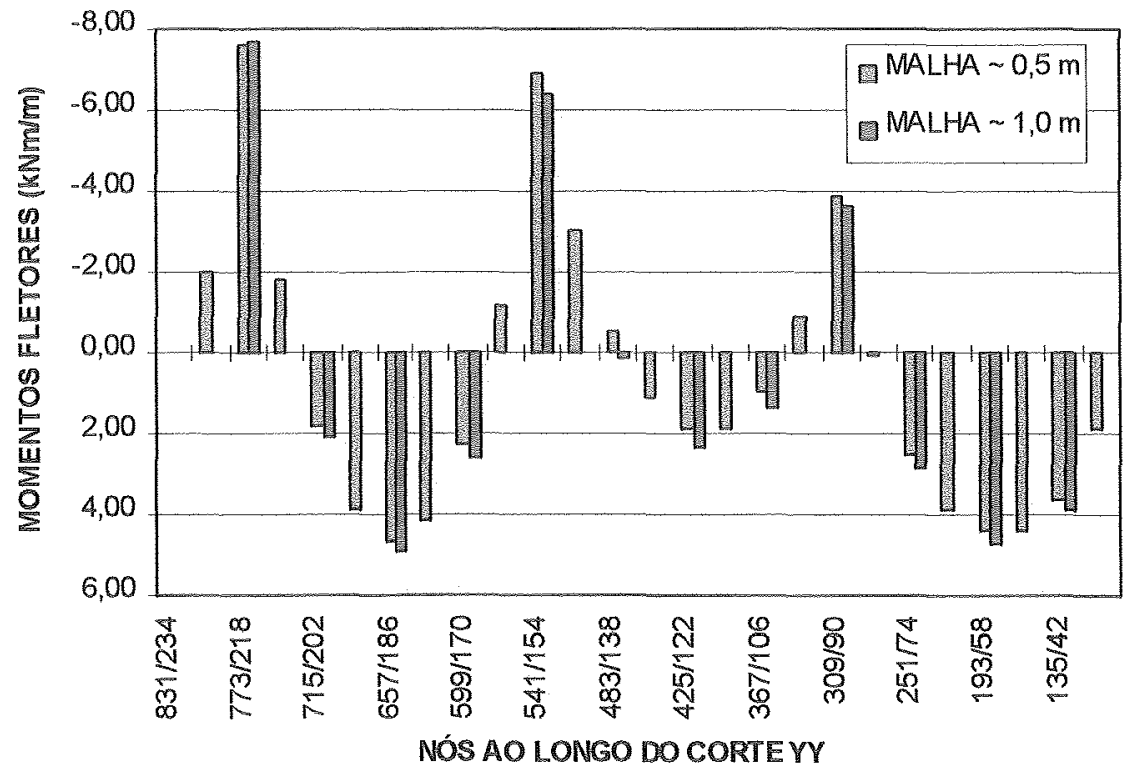

FIGURA 4.9 - Momentos fletores ao longo do Corte $Y$ (ver Figuras 4.3 e 4.4), obtidos através da análise com o método dos elementos finitos 


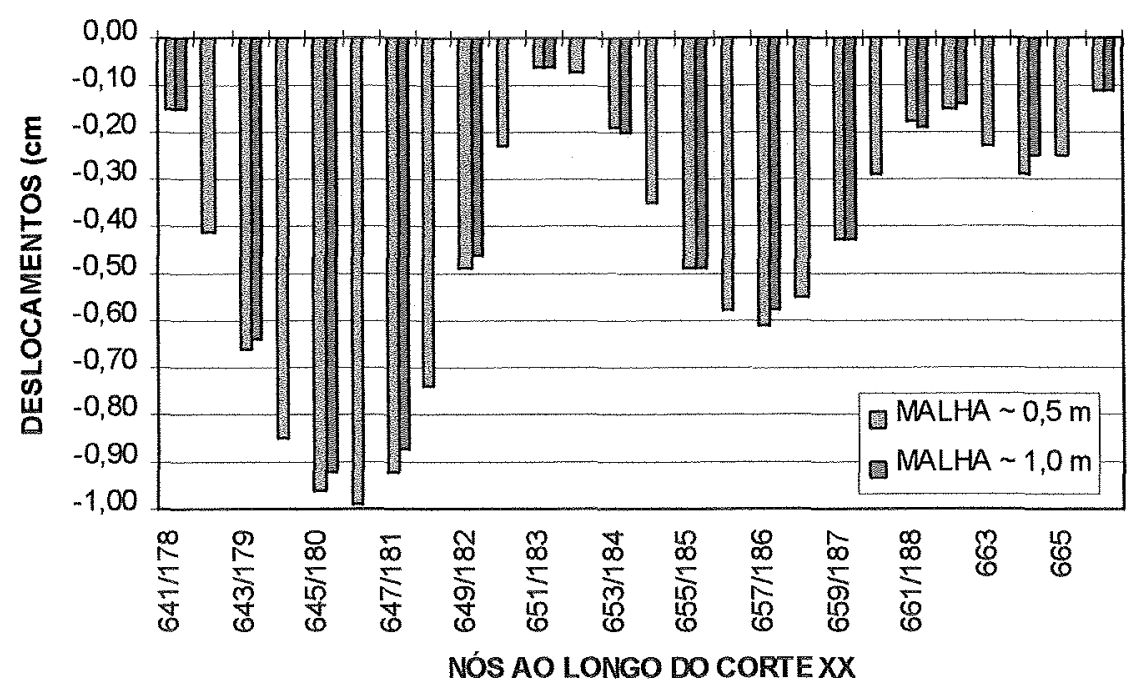

FIGURA 4.10 - Deslocamentos ao longo do Corte XX (ver Figuras 4.3 e 4.4), obtidas através da análise com o método dos elementos finitos

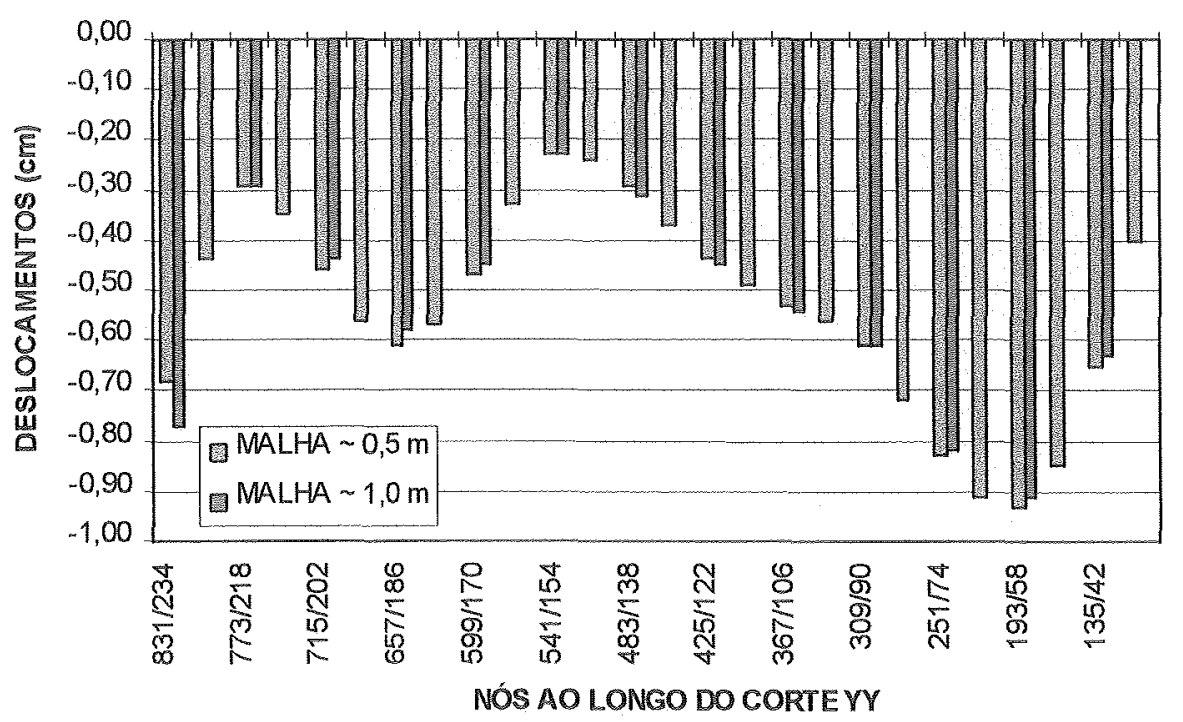

FIGURA 4.11 - Deslocamentos ao longo do Corte $Y$ (ver Figuras 4.3 e 4.4 ), obtidas através da análise com o método dos elementos finitos 
Uma particularidade muito importante da análise de lajes através do método dos elementos finitos é que ela possibilita, por utilizar elementos de placa, a apresentação dos resultados de esforços solicitantes através de envoltórias ou curvas de isovalores ao longo do pavimento analisado, permitindo assim análises mais precisas, prinçipalmente no que diz respeito ao posterior detalhamento das armaduras. É possível identificar os pontos de inversão nos diagramas de momentos fletores, bem como detectar possiveis comportamentos imprevistos, devido a rigidez insuficiente de algum elemento estrutural, como, por exemplo, o ocorrido na interface das lajes LT03 e LT04, sobre a viga VT 04, em que foram observados momentos fletores positivos (rigidez insuficiente da referida viga). As FIGURAS 4.12 e 4.13 apresentam as envoltórias dos esforços momentos fletores obtidas, respectivamente, para as direções $x$ e y do pavimento analisado.

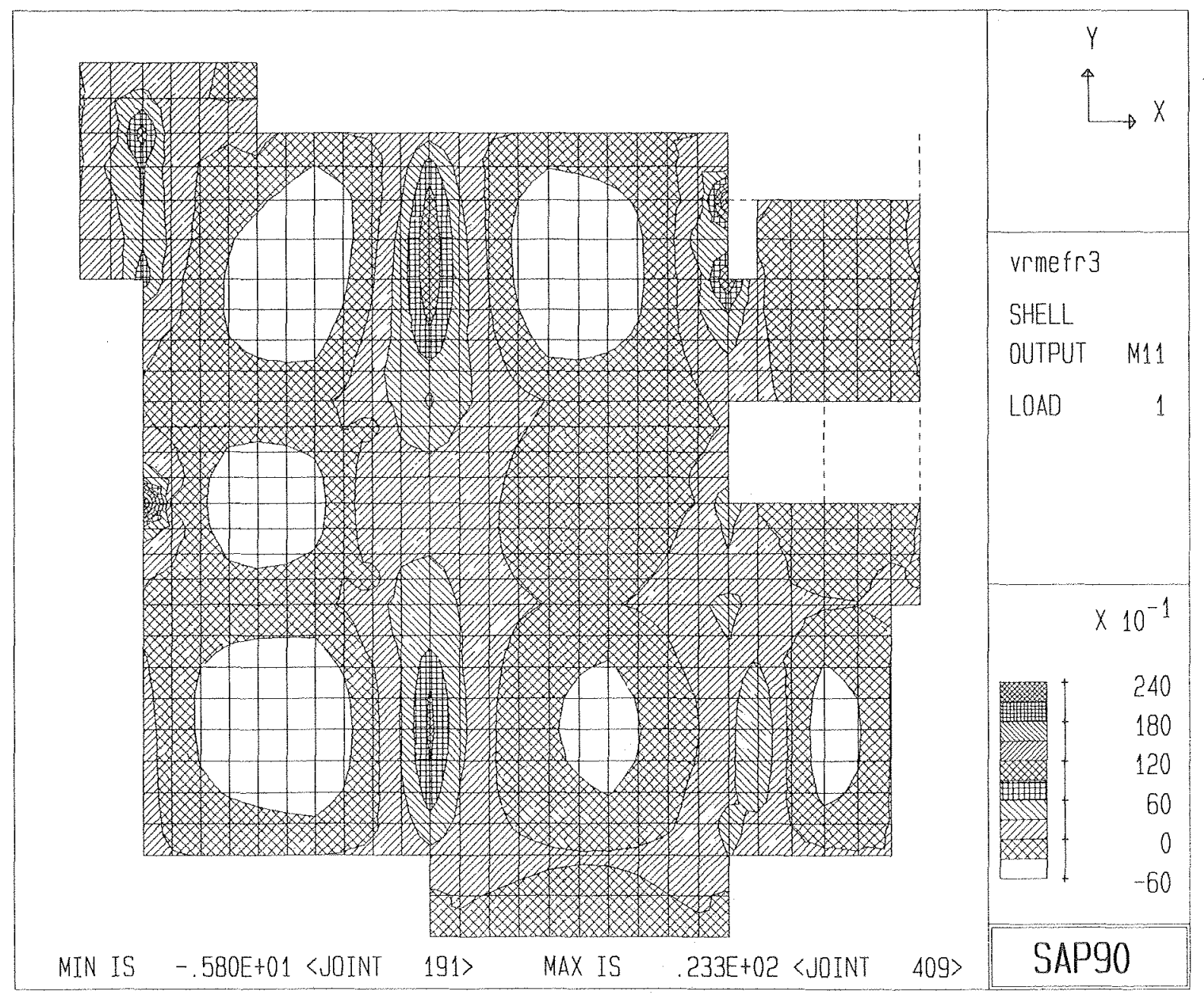

FIGURA 4.12 - Envoltórias dos esforços momentos fletores $M_{11}=M_{x x}(e m k N m / m)$, obtidas através da análise com o método dos elementos finitos 


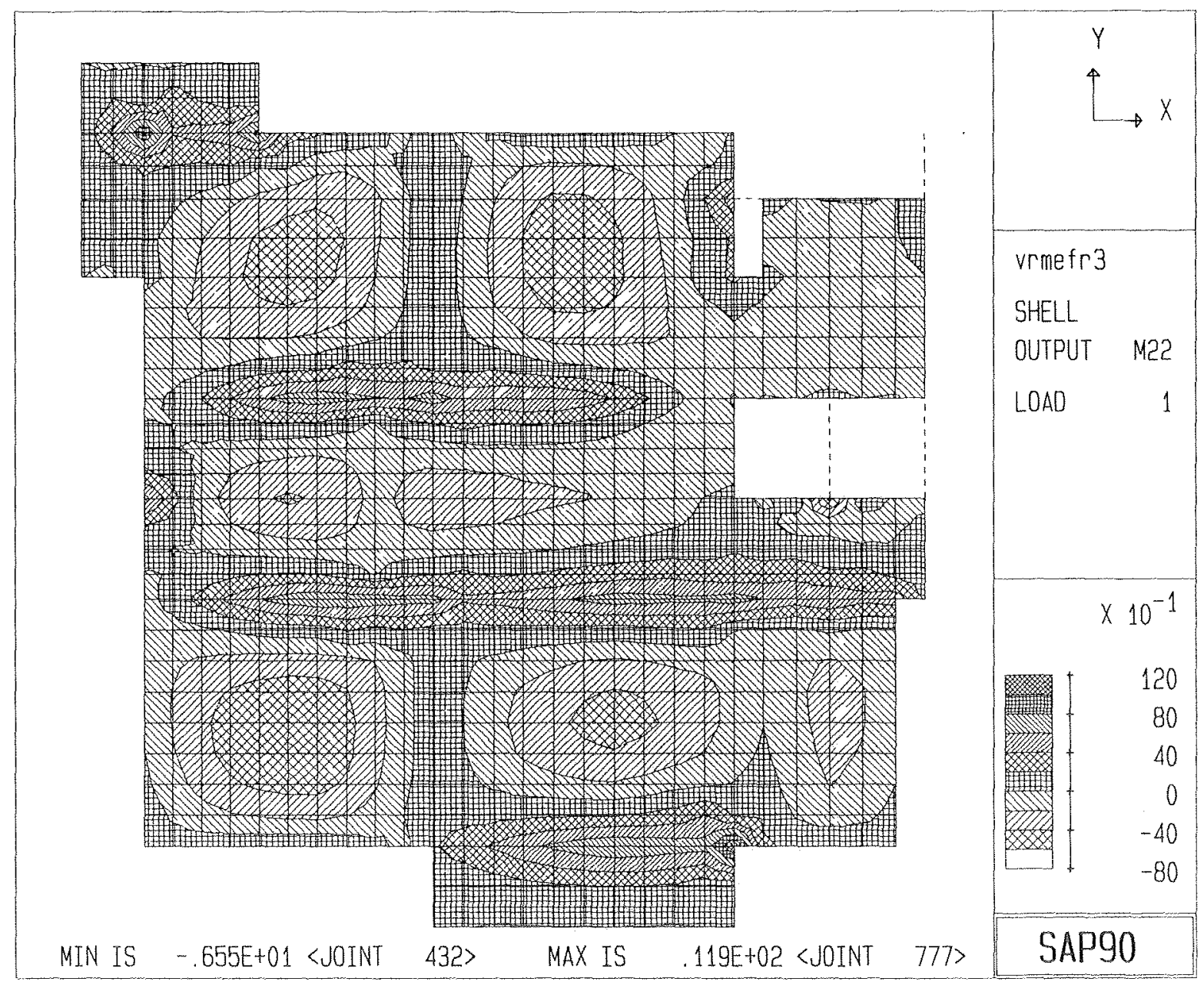

FIGURA 4.13 - Envoltórias dos esforcos momentos fletores $M_{22}=M_{y y}$ (em $\mathrm{kNm} / \mathrm{m}$ ), obtidas através da análise com o método dos elementos finitos

\subsection{COMPARAÇÖES DE RESULTADOS}

O cálculo com auxilio de tabelas do método elástico apresentou, para a direção perpendicular à ação das paredes, resultados muito inferiores aos obtidos das demais análises, principalmente com relação aos momentos fletores positivos, chegando a apresentar valores da ordem de $100 \%$ menores no centro da laje LT14. Para a direção paralela à ação das paredes, apresentou resultados superestimados, tanto para os momentos fletores positivos como para os negativos, com diferenças da ordem de $50 \%$ maiores para os positivos e $100 \%$ maiores para os negativos (interiace LT02/LT08). Na 
região das lajes em balanço, o cálculo com tabelas apresentou valores da ordem de $15 \%$ maiores para os momentos fletores negativos em relação aos observados pelos outros modelos analisados. Com relação aos valores de deslocamentos, foram obtidos valores mais de $100 \%$ menores que nos outros métodos. Entretanto, essas diferenças significativas se devem sobretudo às simplificações que este modelo admite em sua análise, a saber, da indeformabilidade das vigas de apoio das lajes, dos painéis de laje isolados uns dos outros com aproximações de suas condições de vinculação e da consideração das ações das paredes sobre lajes como uniformemente distribuídas sobre as mesmas.

Os modelos analisados através da técnica da analogia de grelha e do método dos elementos finitos apresentaram resultados convergentes tanto nas malhas discretizadas em cada um deles, como também entre si. Os valores obtidos para os deslocamentos foram praticamente idênticos nos dois modelos. Para os momentos fletores negativos, a técnica da analogia de grelha apresentou resultados da ordem de $5 \%$ maiores que os do método dos elementos finitos e para os momentos fletores positivos cerca de $10 \%$ menores na direção perpendicular à da atuação das paredes e de $20 \%$ menores na outra.

Diante dos resultados obtidos dos modelos em análise linear, pôde-se constatar que a técnica da analogia de grelha e o método dos elementos finitos foram os que conduziram a resultados mais precisos e coerentes para as lajes analisadas e que outras formas de pavimentos com características semelhantes às do estudado, principalmente no que diz respeito à existência de paredes sobre as lajes, inviabilizam o uso do cálculo simplificado com tabelas do método elástico. 


\section{MODELO ESTRUTURAL PARA ANÁLISE LIMITE OU PLÁSTICA DAS LAJES DE EDIFÍCIOS}

\subsection{INTRODUÇÃO}

Apresenta-se, no presente capítulo, algumas considerações sobre a análise plástica das lajes de edifícios. Tendo em vista que o cálculo exato de lajes pela teoria da plasticidade não é possivel, conforme já mencionado no trabalho, em frunção do grau infinito de indeterminação estática das mesmas, apresenta-se aqui, um modelo de análise através da Teoria das Charneiras Plásticas, que constitui uma aplicação de um dos teoremas fundamentais do cálculo plástico, a saber, o teorema cinemático ou do limite superior.

São abordadas algumas particularidades da teoria, as hipóteses básicas para sua aplicação e as alternativas para os processos de cálculo possíveis de serem utilizados.

A aplicação da teoria sobre o pavimento tipo do edifício Vitória Régia é feita através da utilização do programa computacional "LAJES", apresentado em RIOS [1991], com versão disponivel no Departamento de Estruturas da Escola de Engenharia de Såo Carlos.

As propriedades do concreto armado, bem como os carregamentos considerados nesta análise, são os mesmos apresentados na introdução do capítulo 4.

\subsection{A TEORIA DAS CHARNEIRAS PLÁSTICAS}

A teoria das charneiras plásticas teve sua primeira publicação em dinamarqês, por INGERSLEV [1921], sendo que sua teoria não era aplicável a muitos casos de lajes por não levar em conta os esforços cortantes ao longo das linhas de plastificação. Um compatriota seu, JOHANSEN [1931], melhorou significativamente a nascente teoria, deduzindo fórmulas para cálculo dos momentos de plastificação em diversos tipos de laje, formulação essa aceita ainda hoje. 
O grande impulso no desenvolvimento da teoria só se deu depois de 1950 e no Brasil, a partir de 1960. Merecem destaque, nesta época, os trabalhos de JONES \& WOOD [1967], na Inglaterra, e os de LANGENDONCK [1970,1975], no Brasil.

Sabe-se que, apesar de ser bem aceita e difundida no meio técnico, a teoria das charneiras plásticas ainda é deixada de lado ou pelo menos relegada a um segundo plano entre as opções de análise das lajes. Isto se explica pelo fato da mesma constituir-se de uma aplicação do teorema cinemático, que conduz a resultados com possibilidades de serem "contra" a segurança, uma vez que o mesmo estabelece um limite superior para a carga de ruína. Esta insegurança teórica, entretanto, não se verifica na prática, uma vez que resultados experimentais demonstram que o valor da carga última ou de ruína é em geral superior à fornecida pela teoria das charneiras plásticas, sendo que esta reserva de resistência decorre, principalmente, dos efeitos de arqueamento e de membrana que surgem na laje quando de sua solicitação sob altos niveis de carga.

\subsubsection{Hipóteses de Cálculo}

As hipóteses básicas para a aplicação da teoria das charneiras plásticas são as seguintes:

a) As partes das lajes limitadas pelas linhas de plastificação e bordas das lajes, permanecem planas durante a deformação por plastificação, ou seja, é admitido um comportamento rigido-plástico para o concreto armado, desprezando-se as deformações elásticas em race das deformações plásticas. Assim sendo, a superfície média da laje plastificada resulta poliédrica, com as charneiras consideradas como retas delimitando regiöes planas. As únicas deformações consideradas são as rotações ao longo das charneiras;

b) Ainda decorrente da consideração de material rigido-plástico, os momentos fletores nos vãos e nos apoios, correspondentes à plastificação das charneiras e denominados momentos de plastificação, são admitidos constantes ao longo dessas charneiras;

c) As lajes devem ser subarmadas, de modo que não ocorra ruptura do concreto comprimido antes do escoamento das armaduras, permitindo assim o completo desenvolvimento das linhas de plastificação e, conseqüentemente, da configuração de ruína; 
d) Não deverá ocorrer ruína prematura por cisalhamento ou punção;

e) Desprezam-se as influências dos esforços de membrana, provenientes do impedimento dos deslocamentos no plano da laje.

\subsubsection{Configurações das charneiras}

Os fatores que influenciam as configurações das chameiras de uma laje são as condições de apoio da mesma, a natureza e a distribuição das cargas e a disposição das armaduras.

Todas as configurações geometricamente possíveis são denominadas configurações possiveis. A cada posicionamento das charneiras, corresponde uma determinada intensidade de carga que fornece a energia consumida na formação e no desenvolvimento das linhas de plastificação. A configuração de ruína é aquela que corresponde à menor carga entre as configurações possiveis, ou ainda ao maior momento de plastificação.

Duas proposições básicas, conforme constam no trabalho de RIOS [1991], permitem a obtenção das configurações de ruina para os diferentes casos de laje:

a) A linha de plastificação entre duas partes de uma laje passa pelo ponto de intersecção dos respectivos eixos de rotação. No caso de borda livremente apoiada ou engastada, o eixo de giro da parte adjacente a essa borda, coincide com a linha de apoio; caso seja um ponto isolado, o eixo de rotação passa pelo ponto de apoio, sendo, porém, sua direção indeterminada. Se houver uma borda livre, o eixo de giro é desconhecido, uma vez que a rotação é livre. Temos ainda que, ao longo de um contorno engastado, forma-se uma charneira superior, correspondente ao momento negativo (FIGURA 5.1)

b) A configuração de ruína é determinada pelos eixos de rotação das partes da laje em colapso e pelas relações dos ângulos de rotação entre eles.

Se a laje está dividida em n partes e todos os seus eixos de giro são conhecidos, então a configuração de ruína depende apenas das (n-1) relações entre as rotações.

Seja uma laje trapezoidal (FIGURA 5.2-a) apoiada em dois lados consecutivos e com um apoio pontual. 


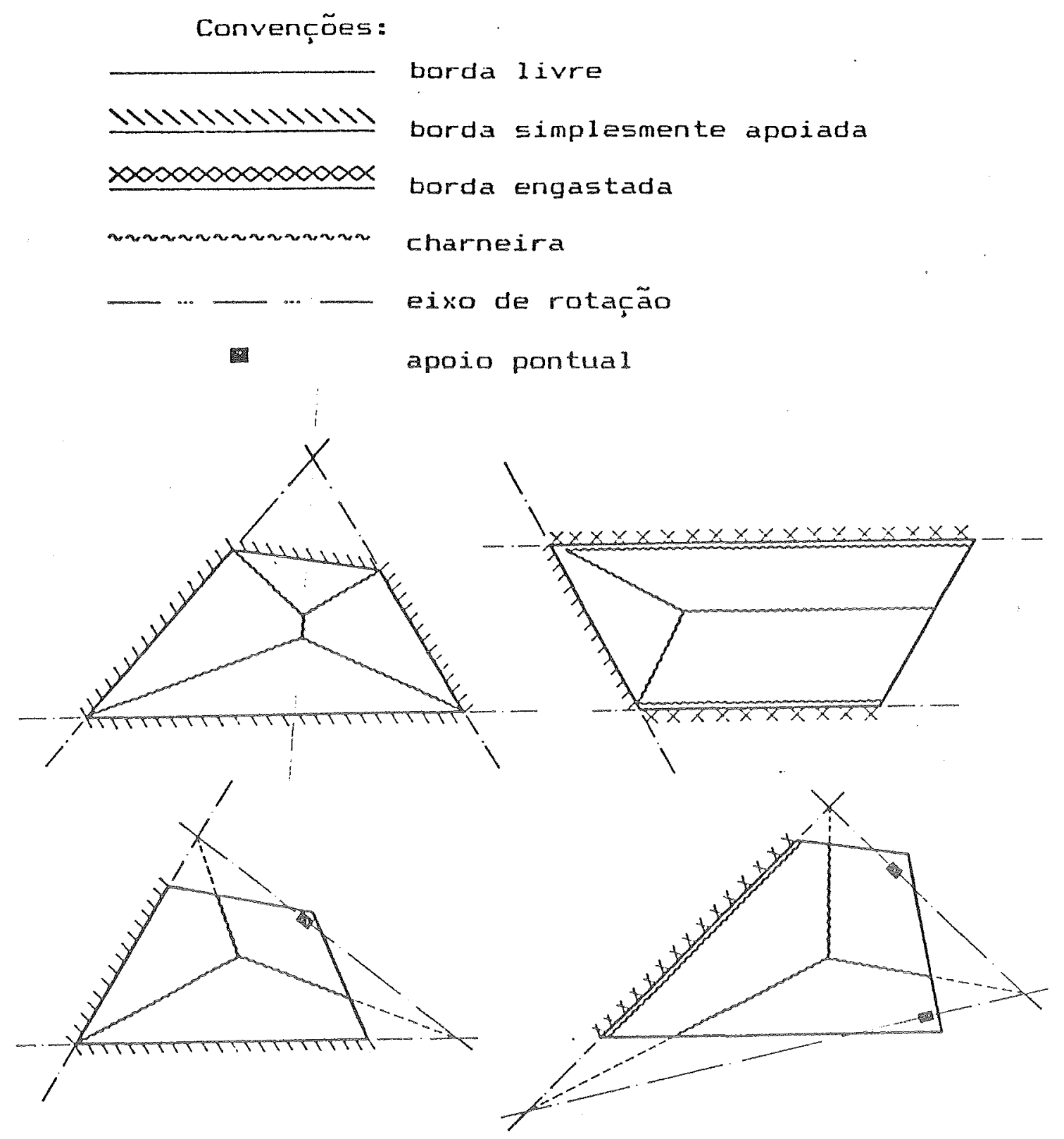

FIGURA 5.1 - Configurações possiveis de charneiras

Existem três eixos de rotação $A B, B C, A C$ e quatro linhas de plastificação, que dividem a laje em três partes planas que giram em torno de seus eixos de rotação. Supondo conhecidos os eixos de giro e as rotaçőes relativas de cada parte da laje $\theta_{1}, \theta_{2}$ e $\theta_{3}$, ao 
cortar a laje deformada por um plano paralelo ao plano dos apoios e com afastamento vertical w (FIGURA 5.2-b), obtém-se uma curva de nivel $A^{\prime} B^{\prime} C^{\prime}$ constituída por segmentos retilíneos paralelos aos eixos de rotação. As distâncias horizontais $a_{i}$, entre os eixos de rotação e os respectivos segmentos da curva de nivel, são iguais às relações de rotações $w / \theta_{i}$, substituindo-se a tangente pelo ângulo, uma vez que 0 ângulo é muito pequeno:

$$
a_{1}=w / \theta_{1} \quad a_{2}=w / \theta_{2} \quad a_{3}=w / \theta_{3}
$$

Para se obter as linhas de plastificação, basta unir os vértices da curva de nivel com os pontos de interseç̧ão dos eixos de rotação.

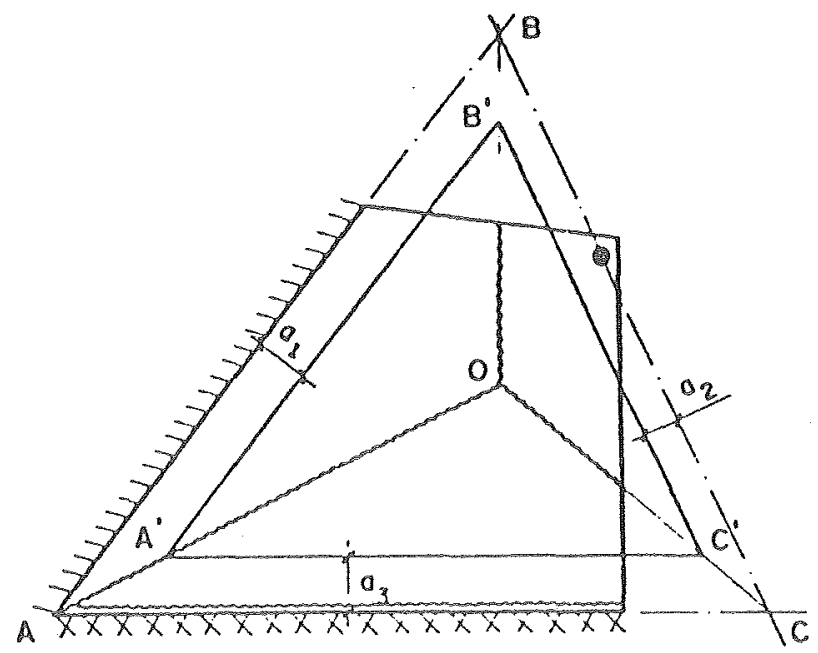

(a)

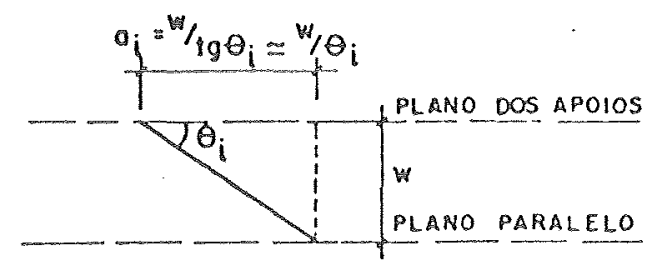

(b)

FIGURA 5.2 - Determinação da configuração de ruína

\subsubsection{Processos de Cálculo}

São dois os processos de cálculo utilizados para a aplicação da teoria das charneiras plásticas: o processo do equilibrio ou das forças nodais, que vem sendo utilizado desde o trabalho original de JOHANSEN [1962], e outro mais recente que é o processo da energia ou dos trabalhos virtuais. 
a) Processo do Equilíbrio ou das forças nodais

O processo do equilíbrio consiste em estabelecer equações de equilíbrio para cada região da laje, delimitada pelas linhas de plastificação. Cada região considerada está em equilíbrio sob a ação de forças nodais, de momentos ao longo das charneiras e de cargas externas. Têm-se, então, para cada parte da laje, três equações de equilíbrio estático, sendo duas equações de momentos em torno dos eixos situados no plano da laje e uma equação de equilíbrio de forças verticais.

b) Processo da Energia ou Processo do Trabalho

O processo da energia é uma aplicação do princípio dos trabalhos virtuais à teoria das charneiras plásticas, assumindo que não há perda de energia na laje enquanto a mesma se deforma sob determinado carregamento.

Admitindo que seja conhecida a configuração de ruína, estabelece-se um giro de valor virtual para as partes da laje, em torno de seus eixos de rotação. A equação de trabalho é obtida igualando-se o trabalho das forças externas $\left(T_{e}\right)$ ao trabalho das forças internas $\left(T_{i}\right)$, ou seja, a energia gasta pelas forças externas durante a deformação virtual da laje é igual à energia consumida pelas charneiras nessa mesma deformação.

Esclarecimentos mais completos sobre os processos de cálculo acima citados, bem como o desenvolvimento de suas formulações, podem ser encontrados em PINHEIRO [1988], em RIOS [1991] e também nas demais obras clássicas do assunto já mencionadas no texto.

\subsection{ANÁLISE DO PAVIMENTO TIPO DO EDIFICIO VITÓRIA RÉGIA ATRAVÉS DA TEORIA DAS CHARNEIRAS PLÁSTICAS}

O cálculo das lajes do Edifício Vitória Régia pela teoria das charneiras plásticas que aqui se apresenta, foi desenvolvido com o auxílio do programa computacional elaborado por Patricia Menezes Rios em sua Dissertação de Mestrado, RIOS [1991]. Em seu trabalho, ela apresenta o desenvolvimento, a partir do processo do equilíbrio, de dois tipos de formulação, a saber, um fixando-se as relações entre os momentos fletores negativos e positivos e a relação entre os momentos fletores positivos e outro fixando-se os valores dos próprios momentos fletores negativos e a relação entre os positivos, obtidos com auxílio do 
cálculo elástico. Este último tipo de formulação é o utilizado no desenvolvimento do programa. As informações sobre instalação, fixação de parâmetros, entrada de dados e outras necessárias ao correto uso do mesmo, encontram-se no referido trabalho.

Ressalta-se que para a compatibilização dos momentos fletores negativos provenientes do cálculo elástico, são apresentados pelo programa alguns critérios possiveis para tal procedimento. $\mathrm{Na}$ análise que aqui se apresenta, foi admitido o critério do maior valor entre a média e $80 \%$ do maior dos momentos fletores negativos observados entre duas lajes contíguas. O programa utilizado admite ainda uma possibilidade de redução nos valores desses momentos fletores negativos provenientes do cálculo elástico, tendo em vista que os mesmos são muito elevados. São propostos para esta redução alguns critérios segundo as indicações de seus respectivos autores. No modelo estudado foi considerado o fator igual a 0,621 , que corresponde à divisão dos momentos fletores do cálculo elástico pelo produto do coeficiente de majoração das ações $(1,4)$ e do coeficiente de minoração da resistência do aço $(1,15)$, segundo indicações de PINHEIRO [1988].

Apresentam-se, na TABELA 5.1, os resultados obtidos do processamento e a comparação dos mesmos com os do cálculo através de tabelas do método elástico. As FIGURAS 5.3 e 5.4 ilustram esses resultados em gráficos comparativos.

TABELA 5.1 - Comparação entre os valores dos esforços momentos fletores obtidos através da teoria das charneiras plásticas e cálculo através de tabelas do método elástico

\begin{tabular}{|l|c|c|c|}
\hline \multicolumn{3}{|c|}{ MOMENTOS FLETORES Mx (kN.m/m) AO LONGO DO CORTE A-A } \\
\hline Posição & Charneiras Plásticas & Tabelas (M. Elástico) & Diferença (\%) \\
\hline Centro LT12 & 2,95 & 3,19 & 8,1 \\
Vinc. LT12/13 & $-5,41$ & $-8,60$ & 58,9 \\
Centro LT13 & 2,98 & 3,34 & 12,1 \\
Vinc. LT13/14 & $-4,20$ & $-6,67$ & 58,8 \\
Centro LT14 & 1,11 & 2,39 & 117,2 \\
Borda LT14 & $-4,29$ & $-6,67$ & 55,4 \\
\hline "Corte A-A: Corte paralelo a VT07, passando pelo centro das lajes LT12/13/14 \\
\hline \multicolumn{4}{|c|}{} \\
\hline \multicolumn{4}{|c|}{ MOMENTOS FLETORES My (kN.m/m) AO LONGO DO CORTE B-B* } \\
\hline Posição & Charneiras Plásticas & Tabelas (M. Elástico) & Diferença (\%) \\
\hline Centro LT13 & 3,35 & 5,53 & 65,0 \\
Vinc. LT13/08 & $-5,05$ & $-8,02$ & 58,8 \\
Centro LT08 & 0,31 & 2,49 & 703,2 \\
Vinc. LT08/02 & $-6,13$ & $-9,82$ & 60,2 \\
Centro LT02 & 4,91 & 6,48 & 31,9 \\
\hline Corte B-B: Corte paralelo a VT09, passando pelo centro das lajes LT13/08/02
\end{tabular}




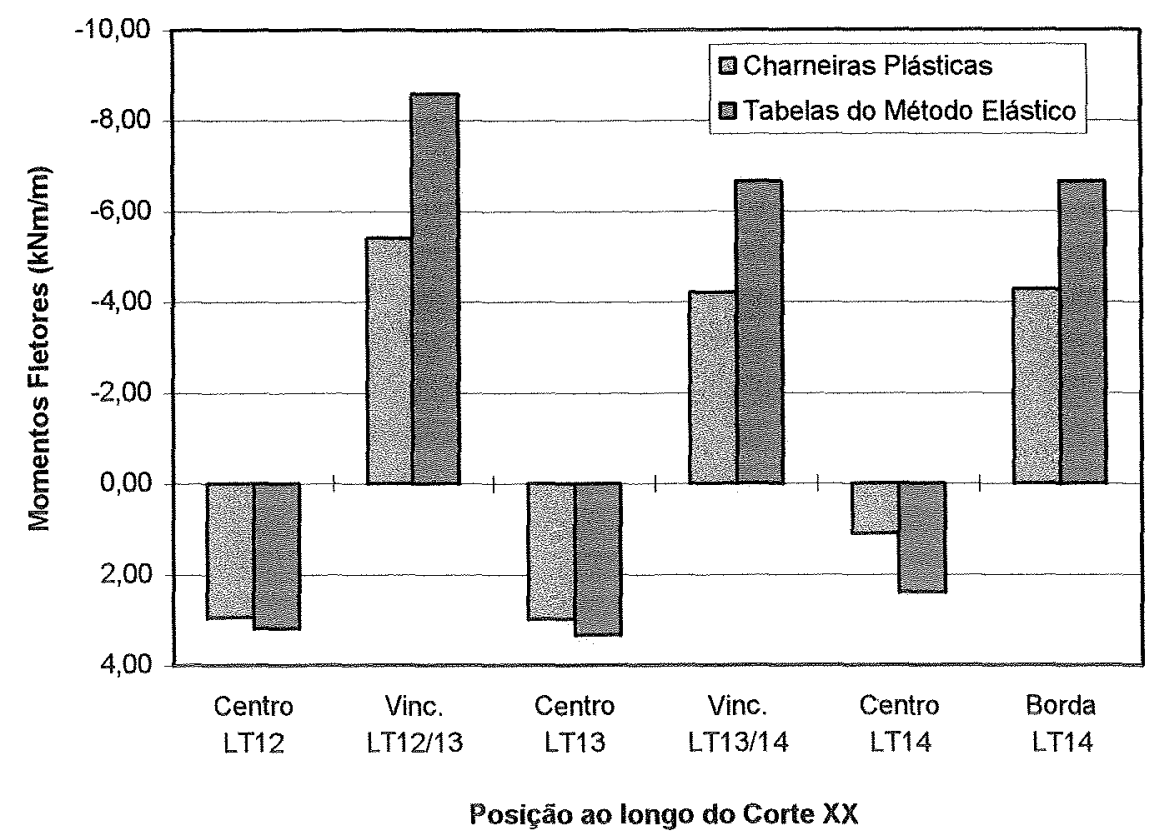

FIGURA 5.3 - Comparações entre os valores dos momentos fletores ao longo do Corte $X X$ (ver tabela 5.1), obtidos através da teoria das charneiras plásticas e do cálculo com tabelas do método elástico

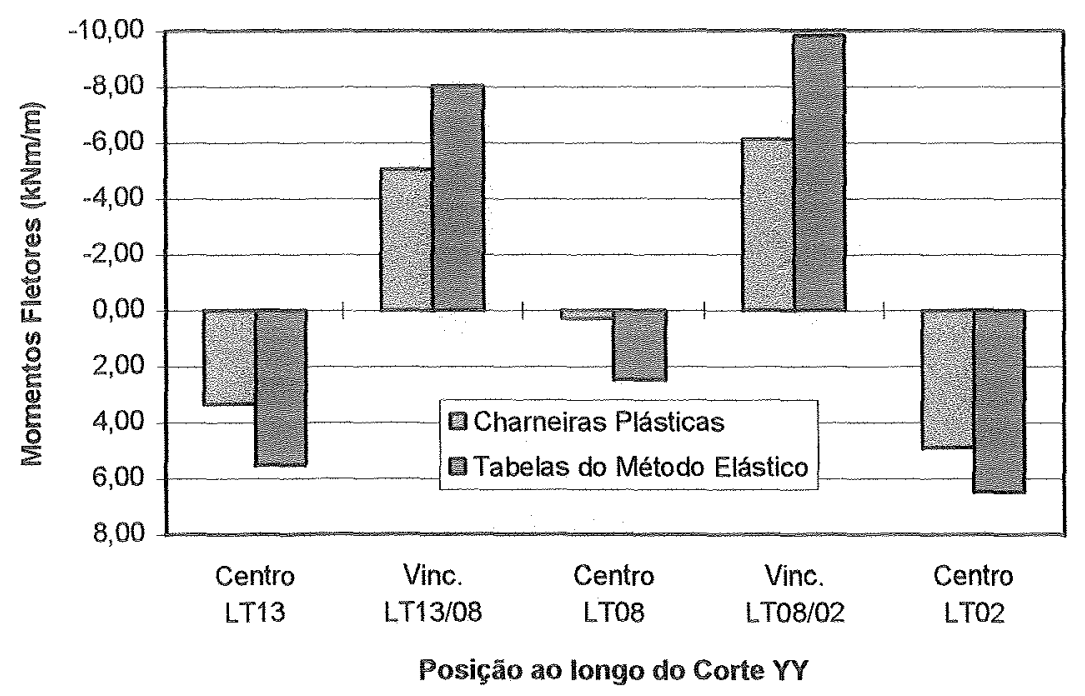

FIGURA 5.4 - Comparações entre os valores dos momentos fletores ao longo do corte $Y Y$ (ver tabela 5.1), obtidos através da teoria das charneiras plásticas e do cálculo com tabelas do método elástico 
De acordo com os valores apresentados na tabela e figuras anteriores, constata-se que a análise através da teoria das charneiras plásticas conduziu a valores de esforços bem menores que os do cálculo através de tabelas do método elástico. Para os momentos fletores negativos, as diferenças observadas foram da ordem de $60 \%$ e para os positivos, as diferenças foram variadas, chegando a picos discrepantes nas lajes com forma mais alongada como nos casos de LT08 e LT14. Essas diferenças são explicadas em função da formulação utilizada pelo programa, conforme já mencionado, que admite a fixação dos momentos fletores negativos provenientes do cálculo elástico (com a consideração da redução de 0,621$)$ e cuja equação geral de solução dos momentos de plastificação pela teoria das charneiras plásticas resulta de tal maneira que quanto maior a relação entre o maior e o menor vão da laje e conseqüentemente menor a relação entre os respectivos momentos fletores positivos, menores serão os momentos de plastificação nas charneiras consideradas.

Tendo em vista que as simplificações admitidas por estes dois modelos são as mesmas, principalmente no que diz respeito à indeformabilidade das vigas de apoio e à consideração de todos os carregamentos como uniformes sobre as lajes, pode-se afirmar que a teoria das charneiras plásticas, enquanto modelo simplificado de análise, apresenta melhores resultados que o cálculo através de tabelas do método elástico, conduzindo a um dimensionamento mais econômico. 


\section{DISTRIBUIÇÃO DAS ARMADURAS}

\subsection{GENERALIDADES}

O bom desempenho de uma estrutura em concreto armado só acontece quando os dois materiais, aço e concreto, trabalham conjuntamente de modo a atender às solicitações próprias a que aquele tipo de estrutura vai ser submetida. A distribuição das armaduras no elemento estrutural constitui assim uma etapa fundamental no desenvolvimento do projeto pois o aço deve estar colocado em posições tais que supram o concreto em suas deficiências. A técnica de armar bem uma estrutura, tanto do ponto de vista de eficiência das armaduras, quanto da sua distribuição mais otimizada, acontece quando se conhece o caminhamento e tipos das tensões resultantes das ações que o elemento recebe e quando se leva em consideração vários detalhes práticos que viabilizem o processo construtivo.

O objetivo básico da técnica de armar uma estrutura de concreto é capacitá-la para absorver os esforços solicitantes de tração (provenientes da flexão e da tração), controlar a a abertura de fissuras nas peças armadas e nos elementos comprimidos aumentar a capacidade resistente e favorecer a segurança na estabilidade para os casos de elevada esbeltez.

A distribuição das armaduras deve ser realizada de maneira racionalizada, ou seja, com base num conjunto de medidas de que minimizem seu custo e otimizem sua fabricação, colocação e montagem. Algumas indicações práticas, conforme mencionado no capítulo dois, são o uso do maior número possivel de barras retas, a concepção com um menor número de posições, a utilização de tipos adequados de emendas e a escolha de malhas e/ou outros conjuntos de barras com antecipação da montagem em fábrica.

O dimensionamento das armaduras das lajes está relacionado com o tipo de modelo estrutural admitido para seu comportamento resistente. Assim, tanto no âmbito da teoria da elasticidade, abrangendo desde modelos mais simples de análise até outros mais refinados, como também no da plasticidade, através da teoria das charneiras plásticas, pode-se determinar os valores dos esforços solicitantes nas lajes. Uma abordagem 
comparativa dos vários métodos para análise de esforços em lajes foi desenvolvida neste trabalho e com base nos resultados obtidos para o exemplo utilizado, pretende-se tratar aqui de alguns princípios básicos relacionados com a distribuição das armaduras em cada modelo estudado.

\subsection{MODELOS ANALISADOS ATRAVÉS DA TEORIA DA ELASTICIDADE}

No dimensionamento das armaduras destes modelos, um primeiro parâmetro a ser analisado deve ser o que estabelece a relação entre os vãos (maior vão/menor vão) das lajes estudadas, permitindo sua classificação como armadas em uma direção (quando esta relação é maior que 2) ou como armadas em duas direções (quando a relação é menor que 2).

\subsubsection{Lajes armadas em uma direção}

Este tipo de laje é dimensionado considerando-se uma faixa de laje, na direção estabelecida como principal, como estrutura linear, para a qual são determinados os esforços e as armaduras principais. Na direção secundária ou transversal devem ser adotadas armaduras de distribuição cujos valores são da ordem de $1 / 5$ da armadura principal para as armaduras positivas e de $1 / 10$ para as negativas, obedecendo às especificações de valores mínimos prescritos pela NBR 6118 [1978] e pelo texio base para sua revisão.

Os arranjos possiveis para as disposições das armaduras são vários. Os mais comumente empregados são os que utilizam barras retas para as armaduras positivas e negativas com ou sem ganchos a $90^{\circ}$. Entretanto, apesar de não serem muito comuns atualmente, também podem ser usados arranjos com barras dobradas da armadura do vão sobre os apoios, conforme proposto por LEONHARDT \& MÖNNIG [1979] e ilustrado na FIGURA 6.1. No presente trabalho, optou-se pela utilização de barras retas com ganchos a $90^{\circ}$.

A verificação da existência de cargas concentradas, pontuais ou lineares (paralelas à direção principal), sobre a laje armada em uma direção, é imprescindivel para o dimensionamento das mesmas, uma vez que tais cargas solicitam a laje também na direção transversal, exigindo assim que sejam dimensionadas as armaduras dessa direção. Nestes casos, para que se possa efetuar o cálculo simplificado da laje como viga, deve-se atender às prescrições da NBR 6118 [1978] no que diz respeito à largura a considerar. 
Com relação aos comprimentos de barras a considerar, deve-se ter para as armaduras positivas, com consideração de ganchos a $90^{\circ}$ nas extremidades, o comprimento correspondente à distância entre as faces externas das vigas de apoio, descontados os respectivos cobrimentos. As barras da armadura negativa devem se estender, de acordo com o diagrama triangular de momentos fletores (considerado já deslocado), até à distância correspondente a 0,25 do vão, conforme prescrições da NBR 6118 [1978].

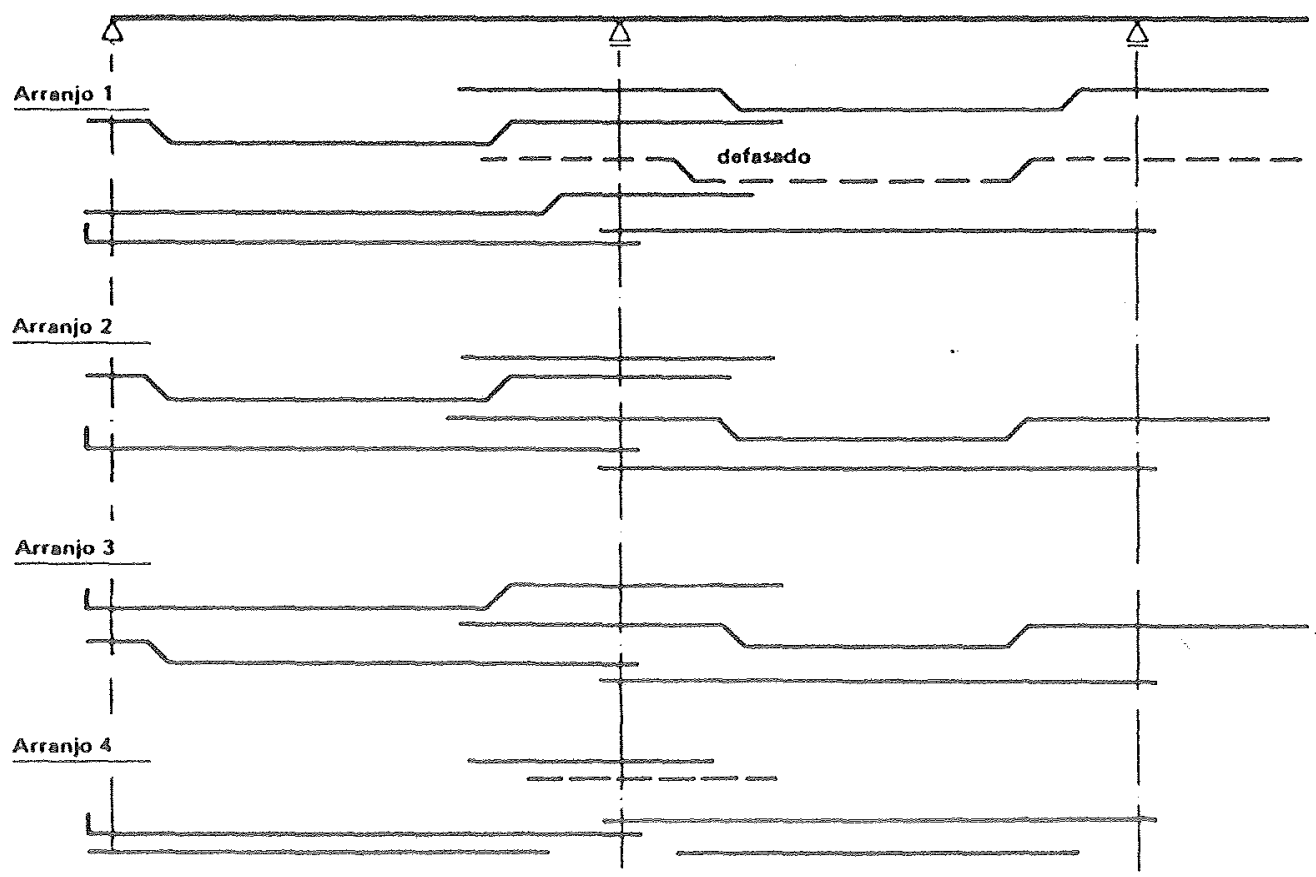

FIGURA 6.1 - Arranjos possíveis para armadura de lajes contínuas

\subsubsection{Lajes armadas em duas direções}

A trajetória das tensões oriundas das ações nas lajes armadas em duas direções é definida pelo caminho mais curto até atingir os apoios, através da flexão nas duas direções consideradas. O comportamento estrutural depende da relação entre os vãos da laje, bem como das condições de vinculação de seus lados ou bordas. O dimensionamento pode ser feito através de algum dos modelos estruturais em análise linear abordados no trabalho.

Com relaçâo às condições de vinculação, especial atenção deve ser dada às lajes extremas do pavimento, com consideração de bordas apoiadas concorrentes num canto. Isto porque quando estes cantos estão garantidos contra a possibilidade de levantamento (o 
que é comum devido à existência de alvenarias e/ou pilares), surgem nesta região, momentos fletores negativos na direção da bissetriz do ângulo e momentos fletores positivos na direção perpendicular a ela (ambos com valores máximos iguais ao do momento volvente). As armaduras para tais solicitações, visando máxima eficiência e otimização, devem ser dispostas nas posições respectivamente superior e inferior do canto de laje, nas direções citadas e conseqüentemente com comprimentos variáveis. Entretanto, esta disposição não é a mais viável do ponto de vista construtivo. Uma disposição mais desejável, conforme sugerida por LEONHARDT \& MÖNNIG [1979], é a que adota armaduras em malha (com áreas iguais às da máxima armadura no vão, quando não se faz uma verificação mais precisa) nas direções dos vãos, embora com consumo maior de aço. Tendo em vista que a grande maioria das lajes de edifício apresentam dimensões não muito grandes, tal efeito pode ser absorvido pelas armaduras colocadas sobre as vigas de borda para consideração de seção $T$ no dimensionamento das mesmas, conforme admitido neste trabalho.

Para os comprimentos das armaduras positivas, são válidas as mesmas considerações feitas para as lajes armadas em uma direção. Com relação às armaduras negativas, as mesmas devem estender-se, conforme prescrito pela NBR 6118 [1978], de acordo com o diagrama de momentos fletores (considerado já deslocado) de base igual ao valor adiante indicado:

- em uma borda engastada, sendo cada uma das outras três bordas livremente apoiada ou engastada, 0,25 do menor vão;

- nos dois lados de um apoio de laje contínua, 0,25 do maior dos vãos menores das lajes contíguas.

6.2.3 Distribuição das armaduras segundo envoltórias de esforços resultantes de análises através de softwares com pós-processadores

Quando são realizadas análises estruturais desenvolvidas com base na aplicação de softwares com pós-processadores, é possível a obtenção dos valores de esforços solicitantes através de envoltórias ou curvas de isovalor para os mesmos, propiciando um dimensionamento mais preciso para os comprimentos das armaduras. Análise desse tipo foi apresentada no trabalho através do método dos elementos finitos. As envoltórias de esforços obtidas paras os momentos fletores nas duas direções principais encontram-se nas FIGURAS 4.12 e 4.13 e são tomadas como base para as considerações que se apresentam aqui.

É importante ressaltar que um bom dimensionamento do pavimento de um edifício exige, além dos conhecimentos técnicos do projetista, seu bom senso. Isto porque não é 
correta a atitude de armar uma laje pelos valores de picos apresentados numa análise numérica, principalmente nas regiões dos apoios ou de cargas concentradas. Estes picos são valores atuantes numa região de laje muito restrita e não devem ser os admitidos para armação da mesma. Um procedimento coerente é efetuar-se uma redistribuição dos esforços obtidos, com base nos critérios de norma para tal. Estes critérios, de acordo com o que foi apresentado no capítulo 3 , mais precisamente no item 3.2.2, visam a garantir que as condições de ductilidade sejam atendidas, bem como que o equilibrio seja satisfeito para todos os elementos estruturais envolvidos.

No presente trabalho é realizada uma redução dos momentos fletores negativos, obedecendo-se aos limites estabelecidos para o coeficiente de redução (conforme item 3.2.2), visando garantir as condições de ductilidade das seções. Tendo em vista que os valores apresentados pelas envoltórias para os momentos fletores positivos, na região dos centros das lajes, atuam em áreas também muito restritas, e diante das dificuldades envolvidas com a garantia do equilíbrio na redistribuição dos esforços, é sugerido no trabalho que o dimensionamento das armaduras nesta região seja efetuado com os próprios valores máximos positivos apresentados pelas envoltórias.

Com relação aos comprimentos a considerar para as barras, é sugerida, para as armaduras positivas, uma distribuição escalonada ao longo dos vãos de laje, a saber, com armadura mínima de comprimento igual à distância entre as faces externas das vigas de apoio, descontados os cobrimentos e acrescidos os ganchos a $90^{\circ}$, e uma armadura complementar na região central com comprimentos determinados em função das envoliórias de esforços. Para as armaduras negativas, foram admitidos os comprimentos suficientes para atender às curvas de isovalor 0 , acrescidos dos comprimentos de ancoragem e ganchos. Ressalta-se que a consideração do deslocamento dos diagramas do valor de $a_{\ell}$, conforme prescrito pela NBR 6118 [1978], é suposto implicitamente atendido nas envoltórias de esforços, tendo em vista a redução dos valores dos momentos fletores negativos.

\subsubsection{Detalhamentos das armaduras obidos para o pavimento tipo do edíício Vitónia Régia}

Apresentam-se, a seguir, nas FIGURAS 6.2 a 6.5, os detalhamentos das armaduras positivas e negativas obtidos pelas análises através do cálculo com o auxilio de tabelas e do método dos elementos finitos. Os respectivos consumos de aço encontram-se nas TABELAS 6.1 e 6.2. O detalhamento das armaduras para os esforços resultantes da análise através da técnica da analogia de grelha não é apresentado tendo em vista a similaridade com o obtido do método dos elementos finitos. Optou-se por detalhar apenas este último 
em função da disponibilidade das envoltórias de esforços por ele apresentadas. Foram admitidas, na execução dos referidos desenhos, além das disposições construtivas mencionadas no capítulo 2 desse texto, as seguintes considerações: a) $1,5 \mathrm{~cm}$ de cobrimento; b) comprimento das armaduras negativas iguais a $2 \times(0,25 \times 0$ maior dos menores vãos + comprimento de ancoragem) + dobras; c) comprimento de armadura negativa do balanço igual a $2 \times$ vão teórico $+(a \ell=1,5 \mathrm{~d})+$ comprimento de ancoragem + dobras; d) comprimento de armadura sobre as vigas de borda igual a 0,2 $\times 0$ menor vão, com área igual a $25 \%$ da área de armadura do vão na mesma direção ou $1,5 \mathrm{~cm}^{2} / \mathrm{m}$ (para consideração da seção $T$ nas vigas) e dobra sobre as vigas igual a $10 \varnothing$; e) segunda dobra de armadura do balanço igual a (2d) ou comprimento ancoragem. Estas recomendações podem ser encontradas em GIONGO [1994], em LEONHARDT \& MÖNNIG [1979] e no TEXTO BASE PARA REVISÃO DA NB-1 [1994].

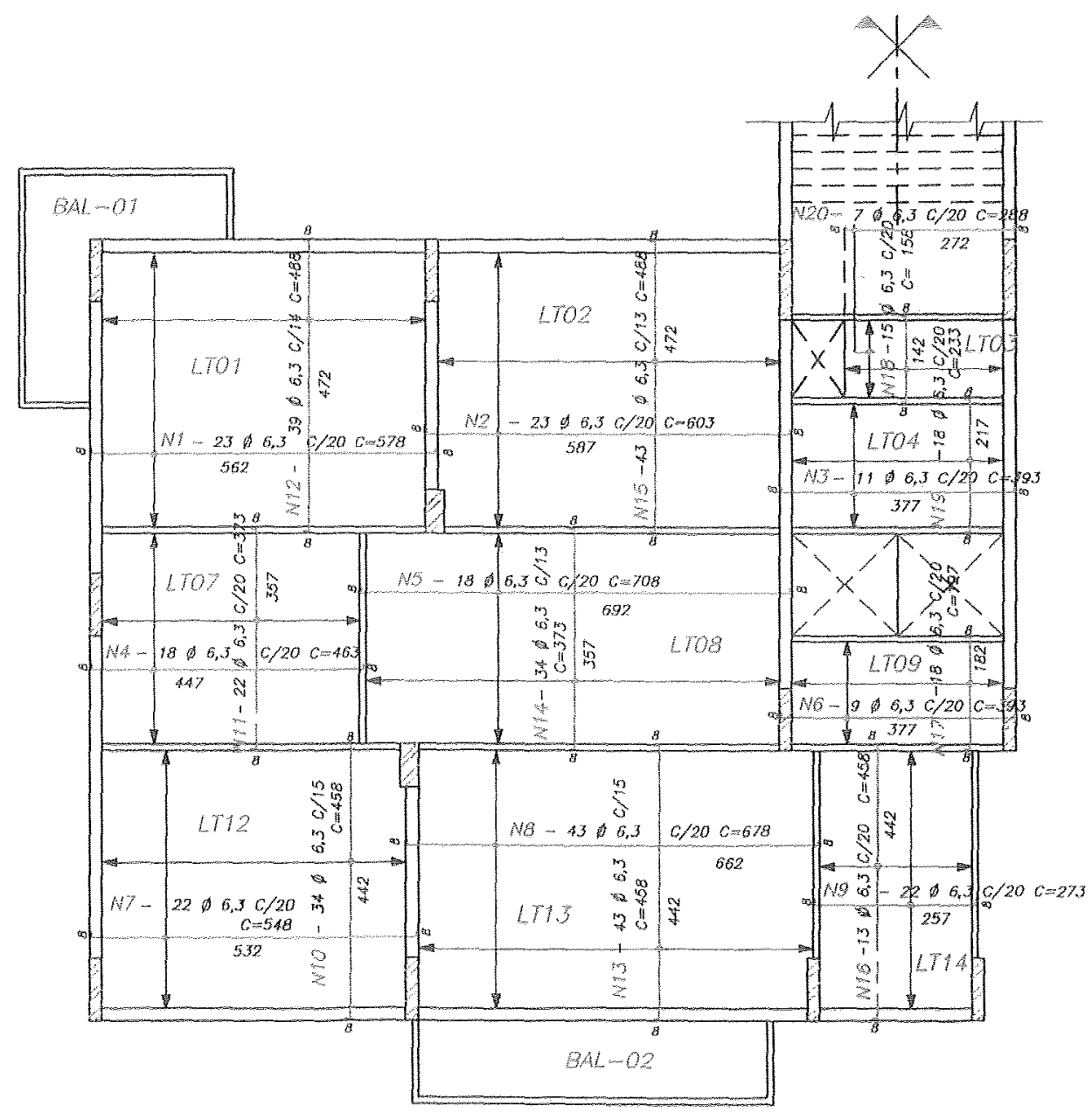

FIGURA 6.2 - Detalhamento das armaduras positivas, obtido através de tabelas do método elástico 


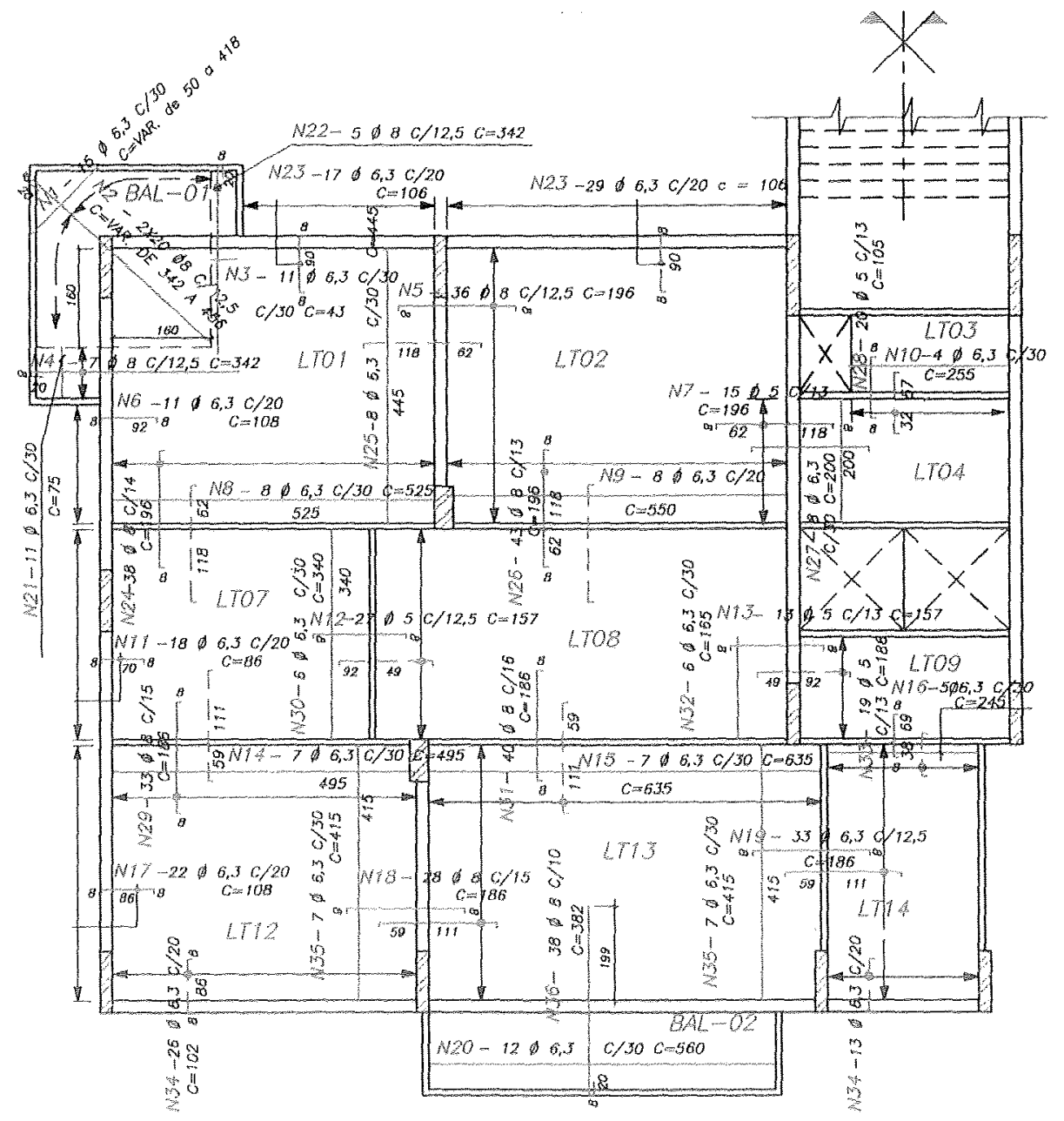

FIGURA 6.3 - Detalhamento das armaduras negativas, obtido através de tabelas do método elástico

TABELA 6.1 - Consumo de aço resultante da análise através de tabelas do método elástico

\begin{tabular}{|c|c|c|c|c|}
\hline \multicolumn{5}{|c|}{ RESUMO DE AÇO } \\
\hline TIPO & DIAM. (mm) & Peso Unit. $(\mathrm{kg} / \mathrm{m})$ & QUANT. (m) & Peso Total (kg) \\
\hline CA-60B & 5 & 0,16 & 148,54 & 24 \\
\hline CA-50A & 6,3 & 0,25 & 2768,66 & 692 \\
\hline CA-50A & 8 & 0,4 & 724,98 & 290 \\
\hline \multicolumn{5}{|c|}{ TOTAL $=1006 \mathrm{~kg}$} \\
\hline
\end{tabular}




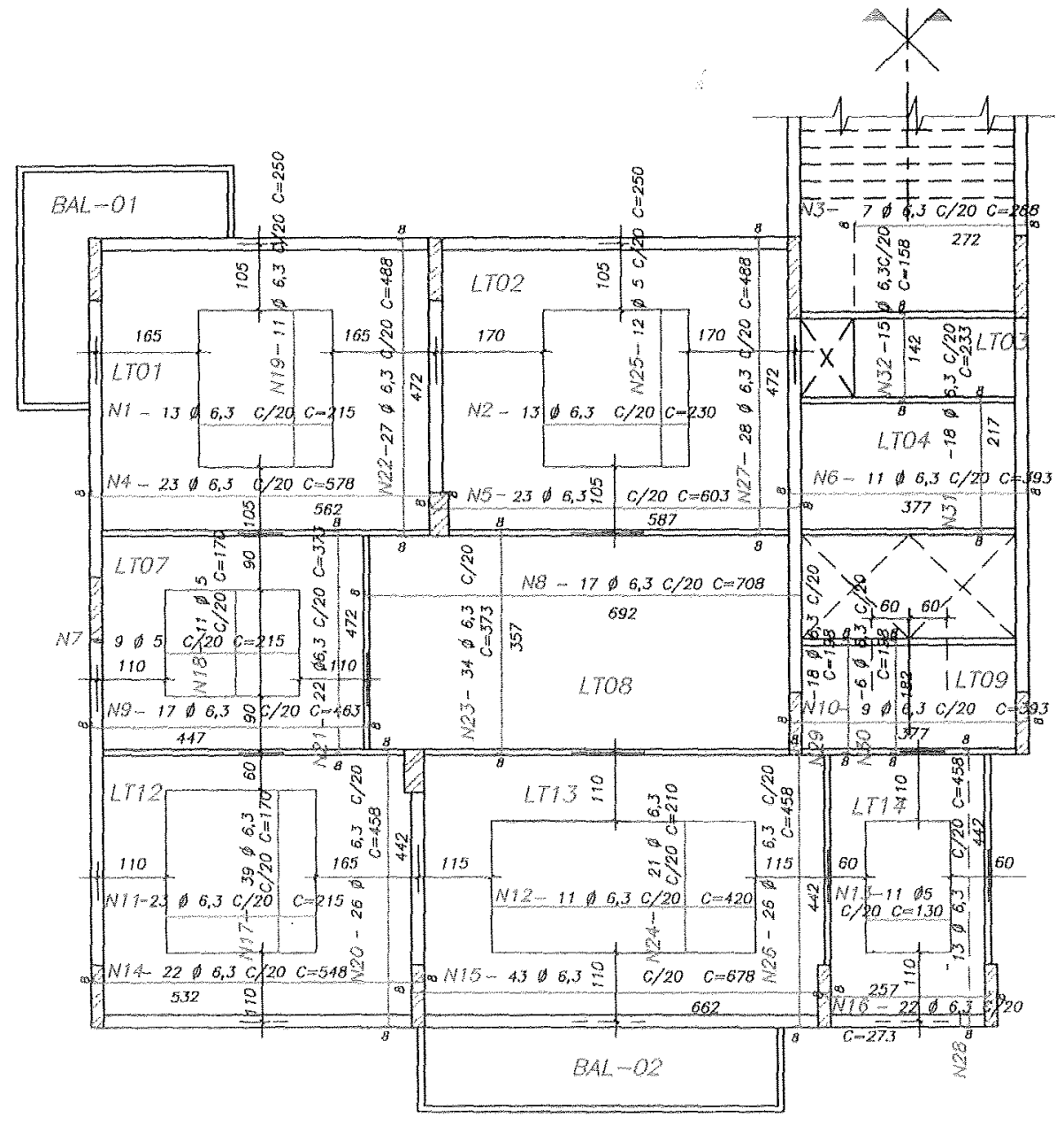

FIGURA 6.4 - Detalhamento das armaduras positivas, obtido através do método dos elementos finitos

TABELA 6.2 - Consumo de aço resultante da análise através do método dos elementos finitos

\begin{tabular}{|c|c|c|c|c|}
\hline \multicolumn{5}{|c|}{ RESUMO DEAÇO } \\
\hline TIPO & DIÂM. (mm) & Peso Unit. $(\mathrm{kg} / \mathrm{m})$ & QUANT. (m) & Peso Total $(\mathrm{kg})$ \\
\hline CA-60B & 5 & 0,16 & 68,05 & 11 \\
\hline CA-50A & 6,3 & 0,25 & 3118,62 & 780 \\
\hline CA-50A & 8 & 0,4 & 421,18 & 168 \\
\hline \multicolumn{5}{|c|}{ TOTAL $=959 \mathrm{~kg}$} \\
\hline
\end{tabular}




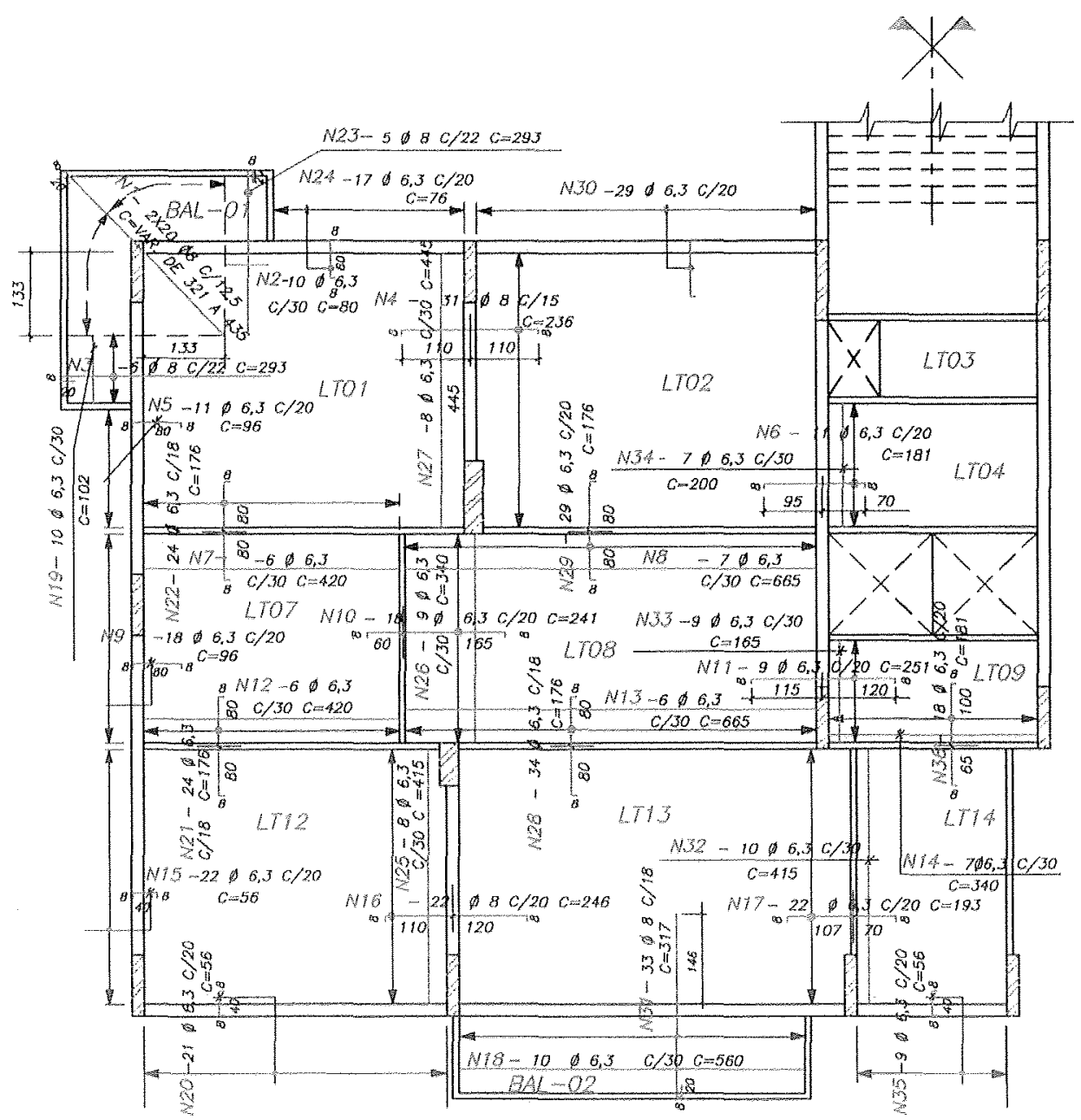

FIGURA 6.5 - Detalhamento das armaduras negativas, obtido através do método dos elementos finitos

\subsection{MODELO ANALISADO ATRAVÉS DA TEORIA DAS CHARNEIRAS PLÁSTICAS}

Para o modelo analisado através da teoria das charneiras plásticas, são utilizados para dimensionamento das armaduras os próprios valores de esforços obtidos da análise.

Com relação aos comprimentos das armadurass, deve-se considerar para as positivas a distância entre as faces externas das vigas de apoio, descontados os cobrimentos e acrescidos os ganchos. Entretanto, para as armaduras negativas, deve-se estabelecer um comprimento adequado de maneira que o ponto de interrupção das mesmas não venha a se possibilitar a ocorrência de um tipo de ruína localizada, uma vez que nesta região da interrupção das barras é desenvolvida uma linha de plastificação negativa. Como não há mais armadura além dessa linha e a resistência do concreto à tração é desprezada, 
o momento de plastificação nessa charneira é nulo. Para a determinação teórica do ponto de interrupção da armadura negativa, pode-se empregar o seguinte procedimento: determina-se uma linha ao longo dos pontos onde a armadura será interrompida. Esta linha delimita uma nova laje, suposta apoiada ao longo da mesma e que deve resistir aos mesmos esforços que a laje original, pois, do contrário, conduzirá a placa à ruína, através das formação da charneira ao longo dos pontos onde a armadura foi interrompida. $O$ desenvolvimento de expressões para o cálculo do ponto de interrupção das armaduras negativas para vários casos de vinculação de lajes, pode ser encontrado em RIOS [1991. Não são explicitados aqui em função da utilização de programa computacional para realização dessa análise, conforme já abordado no trabalho.

Os detalhamentos das armaduras positivas e negativas resultantes da análise através da teoria das charneiras plásticas, encontram-se nas FIGURAS 6.6 e 6.7 e o respectivo consumo de aço na TABELA 6.3 .

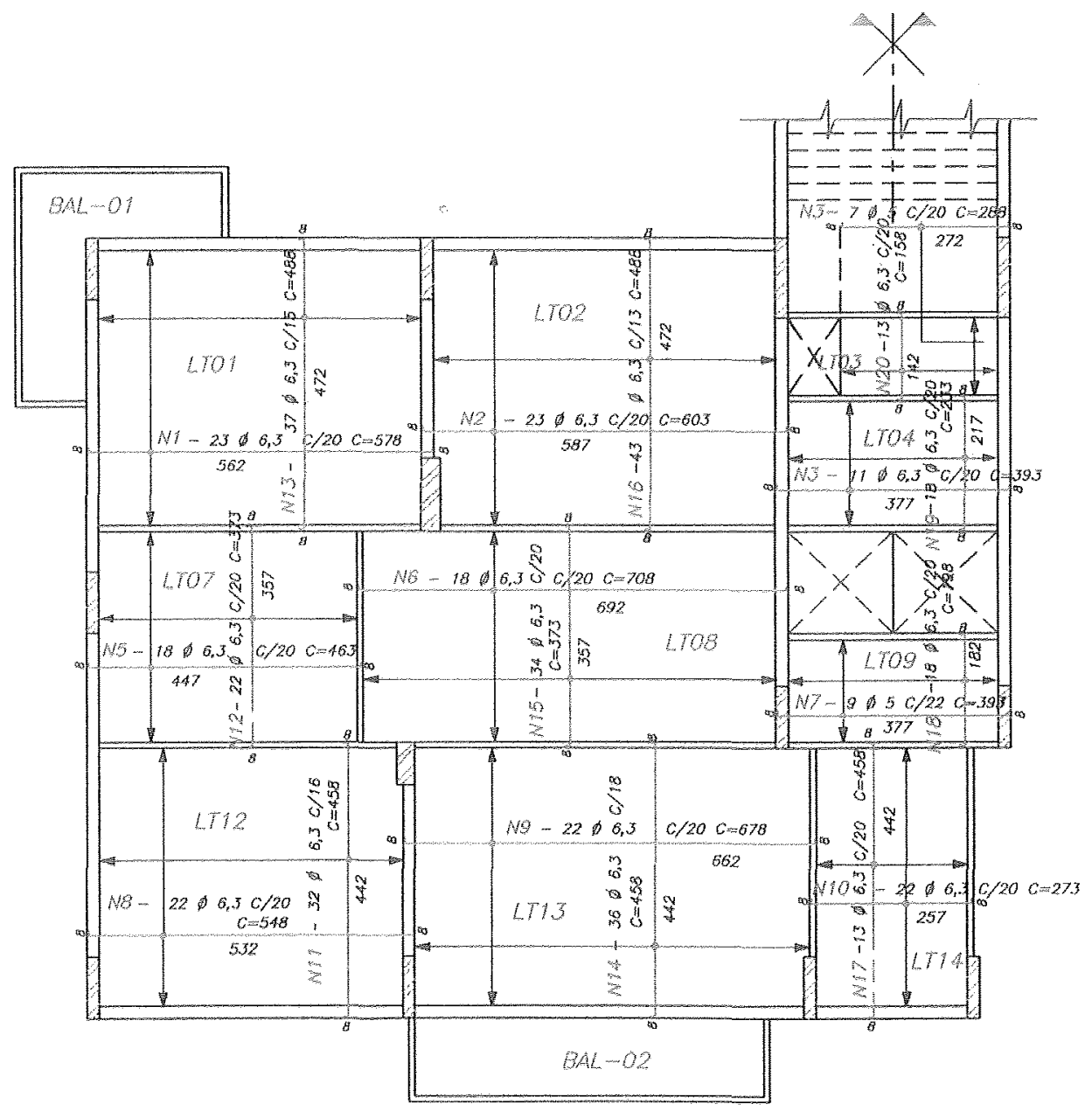

FIGURA 6.6 - Detalhamento das armaduras positivas, obtido através da teoria das charneiras plásticas 


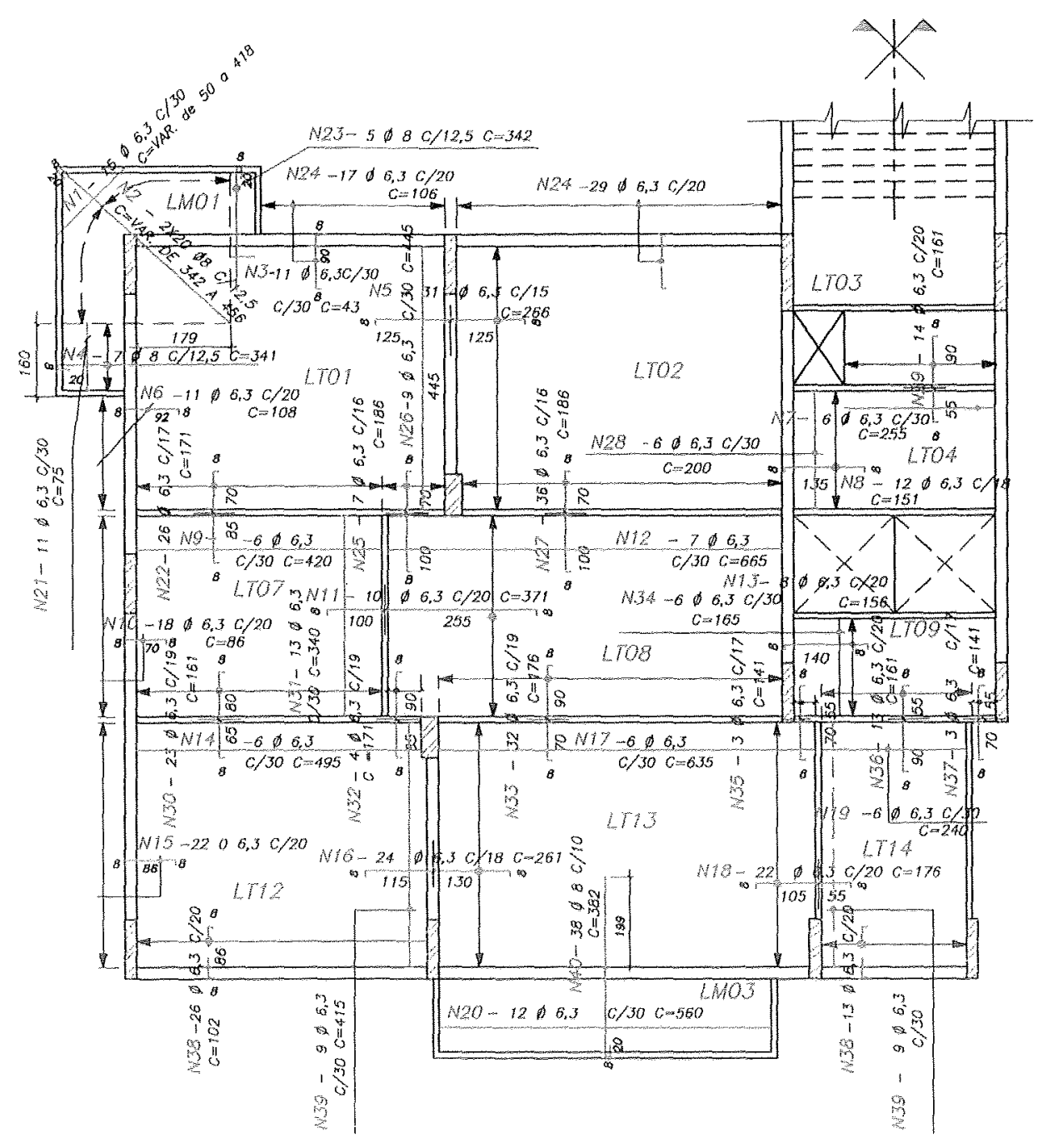

FIGURA 6.7 - Detalhamento das armaduras negativas, obtido através da teoria das charneiras plásticas

TABELA - 6.3 - Consumo de aço resultante da análise através da teoria das charneiras plásticas

\begin{tabular}{|c|c|c|c|c|}
\hline TIPO & DIÂM, (mm) & Peso Unit. (kg/m) & QUANT. (m) & Peso Total (kg) \\
\hline CA-60B & 5 & 0,16 & 55,53 & 9 \\
\hline CA-50A & 6,3 & 0,25 & 3324,75 & 831 \\
\hline CA-50A & 8 & 0,4 & 345,73 & 138 \\
\hline \multicolumn{5}{|c|}{ TOTAL $=978 \mathrm{~kg}$} \\
\hline
\end{tabular}




\subsection{UTILIZAÇÃO DE TELAS SOLDADAS NO DIMENSIONAMENTO DE PAVIMENTOS DE EDIFÍCIOS}

Tela soldada é uma armadura pré-fabricada, formada por fios de aço longitudinais e transversais sobrepostos e soldados entre si em todos os pontos de cruzamento, formando malhas quadradas ou retangulares.

A matéria-prima utilizada na produção das telas soldadas é o fio máquina, produzido por laminação a quente. Ele é fornecido em rolos com resistência mecânica de 400 a $500 \mathrm{MPa}$ e diâmetro entre 5,5 e $14,0 \mathrm{~mm}$, com baixo teor de carbono, condição essencial para se obter boa soldabilidade. Esse fio máquina é submetido a um processo de trefila que se caracteriza pela passagem forçada do fio através de uma seqüência de fieiras. Obtêm-se por este processo fios de conformação superficial lisa, com diâmetro entre 2,0 e $9,0 \mathrm{~mm}$, em aço CA 60, e com diâmetro entre 10,0 e 12,5 mm em aço CA 50B.

As normas técnicas relacionadas com sua fabricação e utilização são a NBR 7480 Barras e fios de aço destinados a armaduras para concreto, a NBR 7481 - Tela de aço soldada para armadura de concreto e a NBR 5916 - Junta de tela soldada para armadura de concreto - ensaio de resistência ao cisalhamento.

As telas soldadas podem ser fornecidas em rolos ou painéis, segundo os seguintes limites:

ROLOS: fíos longitudinais até $4,2 \mathrm{~mm}$ (inclusive)

fios longitudinais até $7,1 \mathrm{~mm}$, para armação de tubos

PAINÉIS: fios longitudinais de diâmetro superior ao estipulado acima

Os diâmetros dos fios padronizados săo:

AÇO CA $60: 3,0-3,4-3,8-4,2-4,5-5,0-5,6-6,0-7,1-8,0-9,0(\mathrm{~mm})$

AÇO CA 50B: $10,0=11,2-12,5(\mathrm{~mm})$

Quanto ao espaçamento entre os fios, os padronizados são os de 10,15 e $30 \mathrm{~cm}$.

As dimensões dos painéis e rolos padronizados são:

LARGURA: $2,45 \mathrm{~m}$

COMPRIMENTO: - ROLOS: 60 e $120 \mathrm{~m}$

- PAINÉIS: 4,20 e 6,00 m

FRANJAS: (extremidades das telas após o último nó soldado)

- Na direção longitudinal: metade de um espaçamento

- Na direção transversal: $2,5 \mathrm{~cm}$ 
As telas padronizadas são designadas por letras $(Q, L$ ou $T)$, de acordo com o seu tipo, acrescidas da seção principal do aço que possuem, em $\mathrm{mm}^{2} / \mathrm{m}$.

São três os tipos básicos de telas padronizadas para estruturas de concreto armado:

Tipo $\mathbf{Q}$ - Área de aço longitudinal igual à área de aço transversal, usualmente em malhas quadradas

Tipo L - Área de aço longitudinal maior que a área de aço transversal, usualmente em malhas retangulares

Tipo T - Área de aço transversal maior que a área de aço longitudinal, usualmente em malhas retangulares

Quando as letras $Q, L$ ou T estiverem acompanhadas da letra " $A$ ", indica que a tela foi produzida com aço CA $50 \mathrm{~B}$.

Em um projeto com telas soldadas, cada painel diferente recebe um número e tem suas características discriminadas na "Relação das Telas". As indicações da posição, designação e dimensões das telas a serem utilizadas, são representadas graficamente por meio de retângulos em escala, com uma de suas diagonais traçadas.

Quando as dimensões dos painéis de tela não forem suficientes para vencer os vãos necessários, deve-se proceder emendas de painéis por simples sobreposição, sem necessidade de amarração com arame recozido. Os comprimentos destas emendas possuem valores fixos e são de 3 espaçamentos de malha para as armaduras principais $\mathrm{e}$ de 1 espaçamento de malha para as armaduras de disíribuição.

Com relação aos comprimentos de ancoragem, estes são normalmente reduzidos, em função da introdução de um nó soldado (ou cruzeta) dentro da estrutura de apoio. Assim sendo, o comprimento de ancoragem, para regiōes comprimidas, resulta da rodem de um espaçamento de malha mais uma franja de tela e, para as regiões tracionadas, de um espaçamento de malha, acrescido de uma franja de tela e da altura da laje que está sendo armada. No presente trabalho, optou-se por estender as malhas até as faces externas das vigas de apoio, descontando-se os cobrimentos, e garantindo-se assim, os comprimentos acima mencionados.

Quando há necessidade de se cortarem painéis ou rolos de telas soldadas, a forma mais econômica de fazê-lo é delinear as linhas de corte numa das seguintes posições: metade, terços médios ou quartos médios.

Esclarecimentos complementares sobre o uso de telas soldadas podem ser encontrados nos catálogos do IBTS - Instituo Brasileiro de Telas Soldadas, órgão criado pelos fabricantes de telas soldadas com o intuito de difundir entre todos os segmentos da construção civil, um amplo conhecimento de onde, como e porque utilizar telas soldadas. 
Para o detalhamento das armaduras das lajes do pavimento tipo abordado no trabalho com a utilização de telas soldadas, foram tomados os valores de esforços obtidos da análise através do método dos elementos finitos, em função da facilidade de obtenção dos comprimentos e/ou larguras a considerar para cada tela através das envoltórias de esforços fornecidas por este modelo. Entretanto, ressalta-se que poderiam ser admitidos os valores de quaisquer das análises realizadas. O que se propõe aqui é apenas uma opção de detalhamento, a ser comparada com a obtida pela respectiva análise. Nas FIGURAS 6.8 e 6.9 apresentam-se, pois, os detalhamentos das armaduras positivas e negativas das lajes do pavimento tipo do edifício Vitória Régia, obtidos com a utilização de telas soldadas. $O$ resumo das telas, com o respectivo consumo de aço, encontra-se na TABELA 6.4.

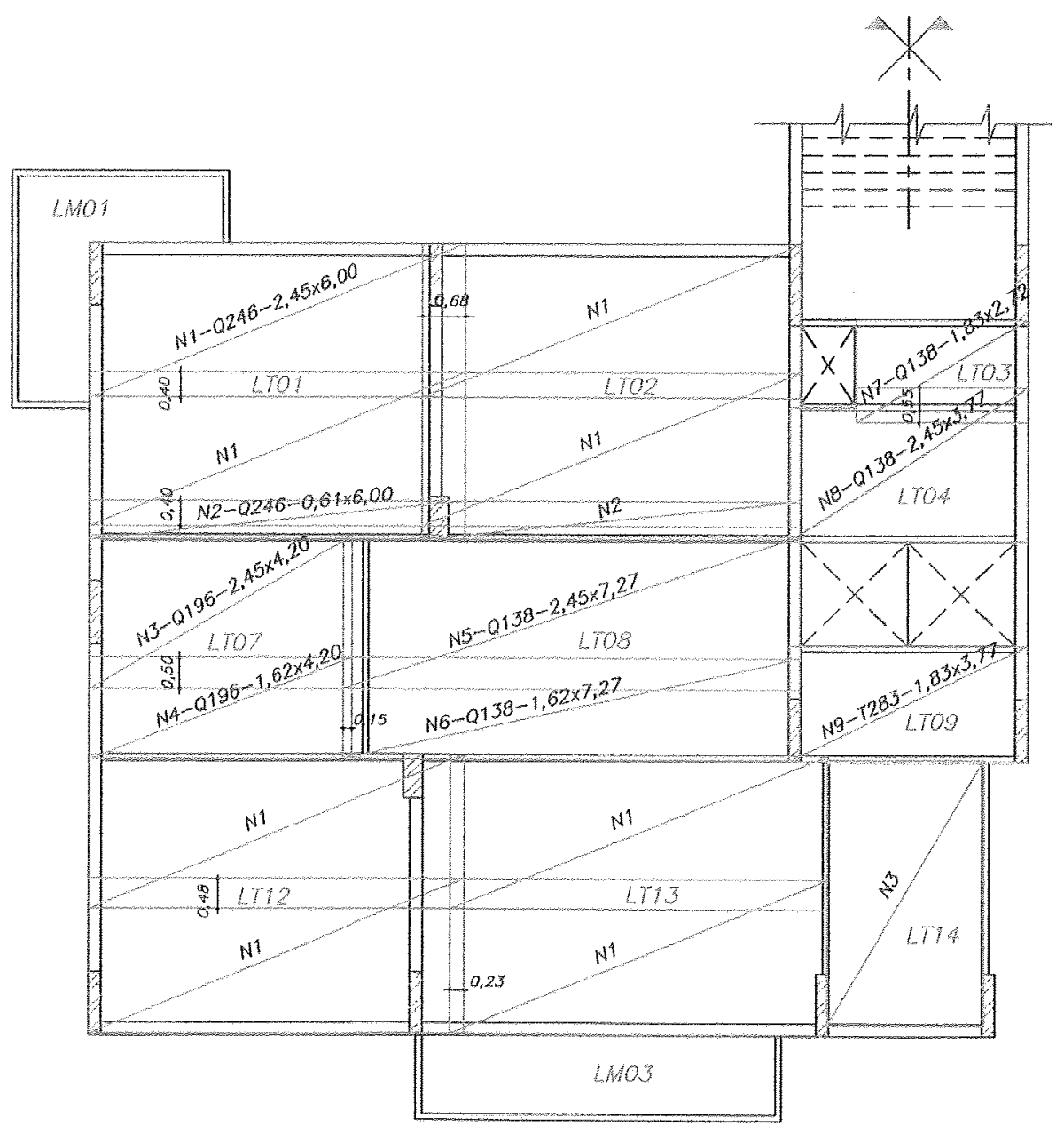

FIGURA 6.8 - Detalhamento das armaduras positivas, obtido com a utilização de telas soldadas 


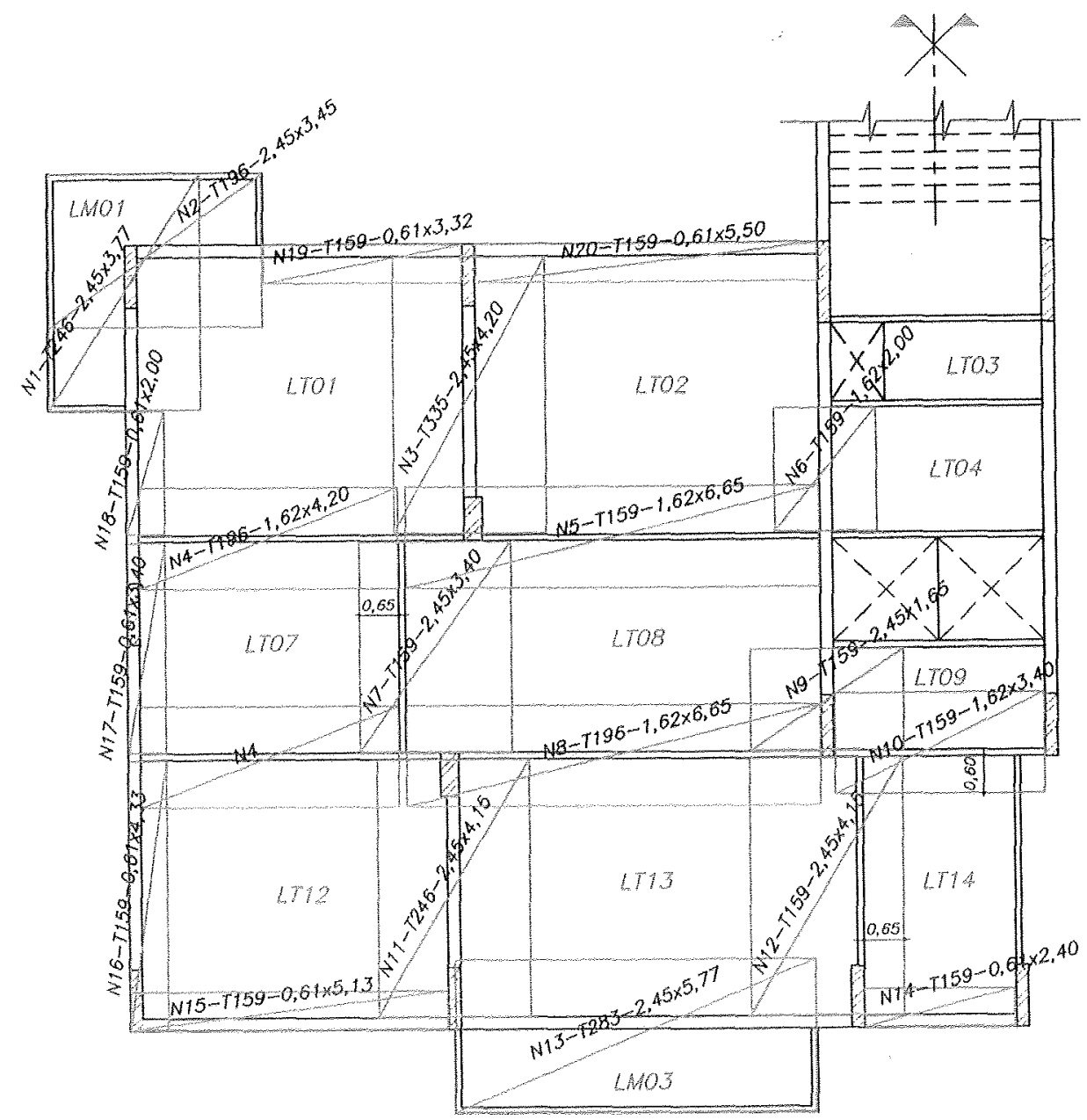

FIGURA 6.9 - Detalhamento das armaduras negativas, obtido com a utilização de telas soldada

TABELA 6.4 - Consumo de aço resultante do dimensionamento através da utilização de telas soldadas

\begin{tabular}{|c|c|c|c|}
\hline \multicolumn{4}{|c|}{ RESUMO DAS TELAS DE AÇO } \\
\hline Aço & Tipo de Tela & Quant. e dim. (m) & Peso (kg) \\
\hline CA-60 & Q246 & 9 Painéis de $2,45 \times 6,00$ & 517 \\
\hline CA-60 & Q196 & 2 Painéis de $2,45 \times 4,20$ & 80 \\
\hline CA- 60 & Q138 & $21 \mathrm{~m}$ de rolo & 113 \\
\hline $\mathrm{CA}-60$ & T283 & $10 \mathrm{~m}$ de rolo & 64 \\
\hline CA- 60 & T246 & $8 \mathrm{~m}$ de rolo & 46 \\
\hline CA-60 & T196 & $19 \mathrm{~m}$ de rolo & 90 \\
\hline $\mathrm{CA}-60$ & T335 & 1 Painel de $2,45 \times 4,20$ & 32 \\
\hline CA-60 & T159 & $27 \mathrm{~m}$ rolo & 104 \\
\hline
\end{tabular}




\subsection{COMPARAÇÕES ENTRE OS MODELOS ANALISADOS}

O presente capitulo apresentou algumas particularidades relacionadas com a distribuição das armaduras nas lajes de edifícios, bem como os detalhamentos das armaduras positivas e negativas das lajes do pavimento analisado no trabalho, para os dois tipos básicos de modelos propostos, a saber, em análise linear (com o uso de tabelas e através do método dos elementos finitos) e em análise limite ou plástica (através da teoria das charneiras plásticas). Convém ressaltar, entretanto, que não é correto comparar-se os resumos de aço resultantes das análises com modelos simplificados com os resumos dos modelos mais refinados, tendo em vista as distintas considerações admitidas em cada um deles.

Comparando-se, portanto, os consumos de aço resultantes do cálculo com tabelas do método elástico e da teoria das charneiras plásticas, nota-se uma diferença de cerca de $3 \%$ apenas. Sabe-se que a teoria das charneiras plásticas conduz a consumos menores que o obtido para estas lajes. Este fato é em partes justificado pela grande quantidade de lajes com armadura mínima nos dois modelos. Ainda assim, é possível afirmar que esta última análise conduz a um dimensionamento mais econômico para as lajes usuais de edifícios, no que diz respeito aos modelos simplificados de cálculo.

O consumo mais elevado (cerca de 15\%) apresentado pelo detalhamento com utilização de telas soldadas em relação ao respectivo obtido através do método dos elementos finitos, pode ser compensado através do ganho na produtividade durante a construção, uma vez que a grande vantagem da utilização de telas está na otimização dos prazos de execução de forma e concretagem das lajes dos pavimentos tipo nos edificios de múltiplos andares.

Do ponto de vista de dimensionamento, pôde-se notar pelos detalhamentos de armaduras apresentados, que determinadas lajes resultam com armaduras positivas insuficientes, ao se admitirem análises através de métodos simplificados. Este fato é explicado, conforme já mencionado no trabalho, em função da existência de paredes ałuando diretamente sobre as lajes, fato este que inviabiliza a utilização de tais métodos quando dessas ocorrências. 


\section{CONCLUSÕES}

A escolha de um modelo estrutural para a análise das lajes de um edifício depende, principalmente, do grau de dificuldades que se tenha diante da forma estrutural prevista para uma dada concepção arquitetônica. Formas mais simples podem ser dimensionadas, de modo geral, com análises através de modelos simplificados, ao passo que formas mais complexas, com geometrias mais diversas das tradicionais retangulares, exigem modelos mais refinados de análise. Entretanto, mesmo para formas estruturais relativamente simples, modelos simplificados de análise podem conduzir a resultados muito imprecisos, em função da maneira como são considerados os carregamentos atuantes e da consideração ou não da rigidez relativa entre os elementos estruturais.

O pavimento tipo do Edif́cicio Vitória Régia, tomado como exemplo nas análises realizadas no trabalho, apresenta uma forma estrutural simples, com lajes todas retangulares, sendo duas em balanço. Os resultados fornecidos, entretanto, pelos modelos estruturais propostos, foram muito diferentes, com modelos superestimando esforços solicitantes em determinadas regiões e subestimando-os em outras.

O modelo estrutural de análise através das tabelas do método elástico conduziu a valores elevados para os momentos fletores negativos, em relaçăo às outras análises, para todas as regiōes de interface de lajes contíguas. Já para os momentos fletores positivos, nas lajes que possuíam alvenarias atuando sobre as mesmas, apresentou valores que, comparados com os outros modelos mais precisos, estão subestimados, quando considerada a direção perpendicular à linha de ação de alvenaria. Estas diferenças observadas com relação a este modelo são devidas às considerações muito simplificadas que o mesmo admite, a saber, que as vigas são apoios indeslocáveis para as lajes, o cálculo dos painéis de lajes como placas isoladas e a consideração das ações concentradas devidas às paredes como uniformemente distribuídas sobre as lajes. Permite-se, pois, afirmar que este tipo de modelo é aplicável aos casos de lajes com formas usuais retangulares, desde que as mesmas não apresentem paredes atuando diretamente sobre 
elas, fato que conduziria, conforme constatado no trabalho, a um dimensionamento inseguro para as mesmas.

Os modelos de análise através da técnica da analogia de grelha e do método dos elementos finitos conduziram a resultados mais precisos, apresentando tendências de convergência nas malhas propostas para o pavimento em estudo. São modelos que podem ser considerados refinados, tendo em vista a consideração mais apropriada e bem definida que fazem de todas as ações, principalmente das concentradas, bem como da rigidez relativa entre os elementos estruturais. A modelagem das lajes com elementos de placa através do método dos elementos finitos possibilita a apresentação dos resultados através de envoltórias de esforços que permitem uma avaliação mais clara da estrutura do pavimento como um todo. Através dessas envoltórias, é possivel perceber mais diretamente possiveis falhas nas rigidezes de algum elemento estrutural, como no exemplo do trabalho, ocorrido na região de contiguidade entre as lajes LT 03 e LT 04, sobre a viga VT 04, onde foram observados momentos fletores positivos para a laje.

O modelo analisado através da teoria das charneiras plásticas, apesar de fazer praticamente as mesmas considerações da maneira como são dispostas as ações, dos apoios indeslocáveis nas vigas e dos painéis de laje isolados uns dos outros, já mencionadas para o cálculo através de tabelas do método elástico, conduziu a resultados mais coerentes e certamente constitui, dentre os modelos simplificados, o mais indicado.

Com relação ao detalhamento da armaduras, observou-se que a análise através do método dos elementos finitos possibilita uma distribuição mais otimizada e precisa das armaduras. Esclarece-se, entretanto, que foram encontradas dificuldades na maneira de como proceder à redistribuição dos esforços solicitantes, tendo em vista a redução dos "picos" apresentados pelas envoltórias. Foram propostas, no trabalho, algumas consideraçöes a esse respeito e sugere-se que novos estudos sejam realizados de maneira a determinar o procedimento correto a adotar nestes casos.

Pôde-se notar que os consumos de aço apresentados pelos métodos simplificados de análise, a saber, pelo cálculo com tabelas do método elástico e pela teoria das charneiras plásticas, foram muito próximos em função das formas de muitas lajes do pavimento analisado que resultaram com armaduras mínimas para os dois modelos. Entretanto, como se constatou pela ordem de grandeza dos esforços solicitantes, a teoria das charneiras plásticas conduz a resultados bem menores que o cálculo com tabelas.

A opção de detalhamento das armaduras com utilização de telas soldadas apresentou valores próximos para o consumo de aço em relação ao detalhamento pelo respectivo modelo admitido como base para obtenção dos esforços, fato que viabiliza sua utilização nos edifícios de múltiplos pavimentos, em função da otimização que se consegue nas fases de execução das formas e concretagem das lajes dos mesmos. 


\section{REFERÊNCIAS BIBLIOGRÁFICAS}

ALLWOOD, R. J. \& CORNES, G. M.; "A poligonal finite element for plate bending problems using the assumed stress approach"; Int. J. Num. Engrg., 1, 135-149; 1969.

AMERICAN CONCRETE INSTITUTE, Building code requirements for reinforced concrete; ACl 318 M-83; Detroit; 1985.

ARGYRIS, J. H., DUNNE, P. C., MALEJANNAKIS, G. A., SCHELKLE, E.; "A Simple Triangular Facet Shell Element with Applications to Linear and Nonlinear Equilibrium and Elastic Stability Problems"; Comp. Meth. Appl. Mech. Engrg.; 1; 97-131; 1977.

ARGYRIS, J. M.; "Continua and Descontinua"; Proc. Conf. Matrix Methods in Struct Mech.; WPAFB; Ohio; 1965.

ASSOCIAÇÃO BRASILEIRA DE NORMAS TÉCNICAS (ABNT), "Ações e Segurança nas Estruturas: NBR 8681; Rio de Janeiro; 21p.; 1984.

ASSOCIAÇÃO BRASILEIRA DE NORMAS TÉCNICAS (ABNT), "Projeto e Execução de Obras de Concreto Armado: NBR 6118 (NB-1/78)"; Rio de Janeiro; 1978.

BARBOZA, A. S. R.; "Contribuição à Análise Estrutural de Sistemas Lajes-Vigas de Concreto Armado Mediante Analogia de Grelha"; Dissertação de Mestrado, 129p., EESC - USP; São Carlos; 1992.

BARES, R.; "Tablas Para El Calculo de Placas Y Vigas Pared"; Gustavo Gili; Barcelona; 1972.

BASELEY, G. P., CHEUNG, Y. K., IRONS, B. M. and ZIENKIEWICZ, O. C.; "Triangular Elements in Plate Bending - Conforming and Nonconforming Solutions"; Proc. First Conf. on Matrix Methods in Structural Mechanics, Wright-Patterson Air Force Base; Ohio; 1965 (AFFDL - TR - 66 - 80, 1966; AD - 646-300, N.T.I.S.), p. 547-576.

BATHE, K. J., WILSON, E. L. and PETERSON, F.; "SAPIV - A structural analysis program for static and dinamic response of linear systems"; College of Engineering, University of California, Berkeley, Ca., USA; 1974.

BATOZ, J. L., BATHE, K. J. \& HO, L. W.; "A study of three-node triangular plate bending elements"; Int. J. Num. Meth. Engrg.; 15; 1771-1812; 1980. 
BELYTSCHKO, T., STOLARSKI, H., CARPENTER, N.; "A C ${ }^{0}$ TriangularPlate Element with One-Point Quadrature"; Int. J. Num Meth. Engrg.; 20; 787-802; 1984.

BERGAN, P. G. \& NYGARD, M. K.; "Nonlinear Shell Analysis Using Free Formulation Finite Elements"; in: Bergan, P. G., Bathe, K. J., Wunderlich, W., eds.; Finite Element Methods for Nonlinear Problems; Springer Verlag; Berlin; 317-338; 1985.

BERGAN, P.G. \& WANG, X.; "Quadrilateral Plate Bending Element with Shear Deformations"; Comput. \& Struct.; 19; 25-34; 1984.

BRANCO, A. F. V. C. ; "Contribuição para o projeto de lajes cogumelo", Dissertação de Mestrado, EESC-USP, 217p.; São Carlos; 1989.

CEOTTO, L. H. Superestruturas de edifícios comerciais e residenciais: análise suscinta de duas alternativas - ESC - USP - Notas para exame de qualificação, 1985.

CLOUGH, R. W. \& FELIPPA, C. A.; "A refined quadrilateral element for analysis of plate bending"; Proc. Conf. on Matrix Meth. in Struct. Mech.; WPFAB; Ohio; 399-440; 1968.

CLOUGH, R. W. \& FELIPPA, C. A.; "A Refined quadrilateral Element for Analysis of Plate Bending"; Proc. Conf. on Matrix Methods in Structural Mechanics; 399-440; WPAFB; Ohio; 1968.

CLOUGH, R. W. \& TOCHER, J.L.; "Finite element stiffness matrices for analysis of plate bending"; Proc. Conf. Matrix Methods in Struct Mech.; WPAFB; Ohio; 1965.

COMITÉ EURO-INTERNATIONAL DU BÉTON, Code-Modele, CEB-FIP pour les structurs en béton; Paris; CEB, 1978; V.2; Bulletin d'information no 124/125 - F.

COOK, R. \& LADKANY, S.; "Observations regarding assumed-stress hybrid plate elements"; Int. J. Num. Meth. Engrg.; 8; 513-519; 1974.

COOK, R. D., MALKUS, D. S., PLESHA,M. E.; "Concepts and Applications of Finite Element Analysis"; Third Ed.; University of Wisconsin - Madison; John Wiley \& Sons; 1989.

COOK, R.;"Some elements for analysis of plate bending"; ASCE; EMi6; 1453-1479; 1972.

COOK, R.; "Artificial adjustment of element stiffnes with a particular reference to plate bending"; Int. J. Num. Meth. Engrg.; 10; 945-976; 1976.

COOK, R.; "Further improvement of an effective plate bending element"; Comput. Struct;; 6; 93-97; 1976.

COOK, R.; "Two Hybrid Elements for analysis of thick, thin and sandwich plates"; Int. J. Num. Meth. Engrg.; 5; 277-288;1972.

COPE, R. J.; "Nonlinear Analysis of Concrete Slabs"; in: Hilton, E., Owen, R., ed.; Computacioanl Modelling of Reinforced Concrete Structures; Pineridge Press; Swansea; 3-43; 1986. 
CORREA, M. R. S.; "Aperfeiçoamento de Modelos Usualmente empregados no Projeto de Sistemas Estruturais de Edifícios"; Tese de Doutoramento, EESC - USP, 305p.; São Carlos; 1991.

CORREAA, M. R. S.; "Aplicação do método das faixas finitas na análise de estruturas prismáticas"; EESC - USP, São Carlos, Dissertação de Mestrado; 1983.

CZERNY, F.; "Tafeln für vierseitig und dreiseitig gelagerte rechteckplatten (Tabelas para placas retangulares apoiadas em quatro e em três lados)"; Beton-Kalender; Berlin; 65 (1): $305-381 ; 1976$.

DUARTE, H. \& GIONGO, J.S. "Lajes esconsas de pavimentos de edifícios: análise comparativa entre a técnica da analogia de grelha e o métodos dos elementos finitos", XXVIII Jornadas Sulamericanas de Engenharia Estrutural, São Carlos, SP, BR, 1997.

FELIPPA, C. A. \& BERGAN, P.G.; "A Triangular Bending Element Based on an EnergyOrthogonal Free Formulation"; Comput. Meth. Appl. Mech. Engrg.; 61; 129-160; 1987.

FIGUEIRAS, J. A.; "Ultimate Load Analysis of Anisotropic and Reinforced Concrete Plates and Shells"; (Tese de Doutoramento); Depart. of Civil Eng.; University College of Swansea; 1983.

FIGUEIREDO F․, J. R.; "Sistemas Estruturais de lajes sem vigas: subsídios para o projeto e execução"; Tese de Doutoramento, EESC - USP, 298p.;São Carlos;1989.

GIONGO, J. S. Concreto armado: projeto estrutural de edifícios, São Carlos, ESC - USP, 1994.

HAMBLY, E.C.; "Bridge deck behavior"; Chapman and Hall; London; 1976.

HLLERBORG, A.; "Strip method of design"; London; William \& Sons; 225p. (A Wiewpoint publication); 1975.

HORRIGMOE, G.; "Hybrid stress finite element model for nonlinear shell problems"; Proc. 6th Canadian Conf. on Applied Meth.; U.B.C. Vancouver, Canada, 1977.

HU, H.-T. \& SCHNOBRICH, W. C.; "Nonlinear Finite Element Analysis of Reinforced Concrete Plates and Shells under Monotonic Loading"; Comput. \& Struct.; 38; 637-651; 1991.

HUGHES, T., TAYLOR, R. L., KANOKNUKULCHAI, W.; "A Simple and Efficient Finite Element for Plate Bending"; Int. J. Num. Meth. Engrg.; 11; 1529-1543; 1977.

IRONS, B. M.; "Putative High-Performance Plate Bending Element"; Int. Journal Num. Meth. Engrg.; 19; 310; 1983.

JOHANSEN, K. W.; "Linhas de ruptura: Teoria e Prática"; Rio de Janeiro; Ao Livro Técnico; 380 p.; (Traduzido e adaptado dos originais dinamarqueses: Brudlinieteorier e Pladeformler); 1962.

JONES, L.L. \& WOOD, R.H.; "Yield-line analysis of slabs"; London, Thames and Hudson; 1967. 
LANGENDONCK, T.; "Teoria Elementar das Charneiras Plásticas"; São Paulo, ABCP, V. 1; 1970.

LANGENDONCK.T.; "Teoria Elementar das Charneiras Plásticas"; São Paulo, ABCP, V. 2; 1975.

LEONHARDT, F. \& MÖNNIG, E.;"Construções de Concreto"; $2^{2}$ ed.; Rio de Janeiro; Interciência; 1979; Vols. 1 a 6.

LIGHTFOOT, E. \& SAWKO, F.; "Structural frame analysis by eletronic computer: grid frame works resolved by generalised slope deflection"; Engineering, 187, 18-20; 1959.

MARCUS, H.; "Vereinfachte Berechnung Biegsamer Platten ( Cálculo simplificado de lacas fletidas)"; Berlin; Julius Springer; 1929.

MELOSH, R. J.; "A Flat Triangular Shell Element Stiffness Matrix"; Proc. Conf. on Matrix Meth. in Struct. Mech.; 503-509; WPAFB; Ohio; 1965.

MELOSH, R. J.; "A stiffness matrix for the analysis of thin plates in bending"; J. Aeronaut. Sci.; 28 (34); 1961.

MELOSH, R. J.; "Basis of derivation of matrices for the direct stiffness analysis"; A.I.A.A.J.,1, 1631-1637; 1963.

MONTOYA, P. J., MESEGUER, A. G., CABRES, F. M.; "Hormigon Armado"; 7"a ed. ; Editorial Gustavo Gili; Barcelona; 2 v.; 1973.

NEALE, B. K., HENSHELL, R. D., and EDWARDS, G.; "Hybrid plate bending elements"; J. Sound Vib., 23, 101-112; 1972.

PIAN, T. \& TONG, P.; "Rationalization in deriving element stiffness matrix by assumed stress approach"; Proc. Conf. Matrix Meth. in Struct. Mech.; WPFAB, Ohio; 1968.

PIAN, T.; "Element stiffness matrices for prescribed boundary stresses"; Proc. Conf. Matrix Meth. in Struct. Mech., WPAFB; Ohio; 457-477; 1965.

PINHEIRO, L. M.; "Análise Elástica e Plástica de Lajes Retangulares de Edifícios"; Tese de Doutoramento, EESC - USP, 303p.; São Carlos; 1988.

PINHEIRO, L.M.; "Concreto Armado - Tabelas e Ábacos"; Publ. 016/90; EESC - USP; São Carlos; 1986.

PRELORENTZOU, P. A. \& GIORGI, R. C.; "Critérios e Parâmetros de Projetos Estruturais de Edificações - Qualidade das Estruturas de Concreto Armado da ENCOL”; DITEC ENCOL; 1994.

PUGH,E. D., HILTON, E., ZIENKIEWICZ, O. C.; "A Study of Quadrilateral Plate Bending Element with Reduced Integration"; Int. J. Num. Meth. Engrg.; 12; 1059-1078; 1978.

QUIRINO, J. P.; "Introdução ao Método dos Elementos Finitos"; Série Treinamento 227; Acordo SENAI/CESP; Convênio UNESP/CESP; DivisÃo de Treinamento; CESP . Companhia Energética de São Paulo; Ilha Solteira; 1986. 
RIOS, P. M.; "Lajes Retangulares de Edifícios: Associação do Cálculo Elástico com a Teoria das Charneiras Plásticas"; Dissertação de Mestrado, EESC - USP; São Carlos, 1991.

ROCHA, A. M.; "Novo Curso Prático de Concreto Armado", 12a ed.; Rio de Janeiro; Ed. Científica; V. 1; 1971.

SEVERN, R. T. \& TAYLOR, P. R.; "The finite element method for flexure of slabs when stress concentrations are assumed"; Proc. Inst. Civ. Eng., 34, 153-170; 1966.

TAKEYA, T. et alii; "Recomendações para o projeto e a execução da estrutura em lajes cogumelo pertencentes às unidades básicas de saída do plano metropolitano de saúde"; Relatório Técnico; EESC - USP; São Carlos; 1985.

TAYLOR, R. L., SIMO, J. C., ZIENKIEWICZ, O. C. and CHAN, A. C. H.; "The Pat Test - A Condition for Assessing FEM Convergence", Int. J. Num. Meth. Engrg.; 22; 39-62; 1966.

TEXTO BASE PARA REVISÃO DA NB-1-78; 1994.

TIMOSHENKO, S.; "Theory of Plates and Shells"; New York; McGraw Hill; 429p.;1940.

TORBE, I. \& CHURCH, K.; "A general quadrilateral plate bending"; Int J. Num. Meth. Engrg.; 9; 856-868;1975.

WILSON, E. L. \& HABIBULLAH, A.; "SAP90 - A Series of Computer Programs for the Static And Dynamic Finite element Analysis of Structures. User's Manual"; Computers and Structurs; Inc. Berkley, California, 1988.

ZIENKIEWICZ, O. C. \& CHEUNG, Y. K.; "The finite element method for analysis of elastic isotropic and orthotropic slabs"; Proc. Inst. Civil Eng.; 28; 471-488; 1964.

ZIENKIEWICZ, O. C., TAYLOR, R. L., PAPADOPOULOS, P., OÑATE, E.; "Plate Bending Elements with Discret Constraints: New Triangular Elements"; Comput. \& Struct.; 35; 505-522; 1990.

ZIENKIEMICZ, O.C., TAYLOR, R. L., TOO, J. M.; "Reduced Integration Technique in General Analysis of Plates and Shells"; Int. Journal of Num. Meth. Engrg.; 3; 575-586; 1971. 